\title{
Dynamic uplift, recycling, and climate control on the petrology of passive-margin sand (Angola)
}

\author{
Eduardo Garzanti $^{1 *}$, Pedro Dinis ${ }^{2}$, Pieter Vermeesch ${ }^{3}$, Sergio Andò ${ }^{1}$, Annette Hahn ${ }^{4}$, João \\ Huvi $^{5}$, Mara Limonta ${ }^{1}$, Marta Padoan ${ }^{1}$, Alberto Resentini ${ }^{1}$, Martin Rittner ${ }^{3}$, Giovanni Vezzoli ${ }^{1}$
}

${ }^{1}$ Laboratory for Provenance Studies, Department of Earth and Environmental Sciences, University of Milano-Bicocca, 20126 Milano, Italy

${ }^{2}$ MARE - Marine and Environmental Sciences Centre, Department of Earth Sciences, University of Coimbra, Portugal

${ }^{3}$ London Geochronology Centre, Department of Earth Sciences, University College London, London WCIE 6BT, UK

${ }^{4}$ MARUM Center for Marine Environmental Sciences, University of Bremen, Bremen, Germany

${ }^{5}$ Marine and Environmental Sciences Centre, University Katyavala Bwila, Benguela, Angola

*Corresponding author. E-mail: eduardo.garzanti@unimib.it . Tel.: +39-02-64482088

E-mail addresses: eduardo.garzanti@unimib.it (E. Garzanti),pdinis@dct.uc.pt (P. Dinis), p.vermeesch@ucl.ac.uk (P.Vermeesch), sergio.ando@unimib.it (S. Andò), ahahn@marum.de (A.Hahn), hjoaobaptistahuvi@yahoo.com.br (J.Huvi), mara.limonta@unimib.it (M.Limonta), marta.padoan@unimib.it (M.Padoan), alberto.resentini@unimib.it (A. Resentini), m.rittner@ucl.ac.uk (M. Rittner), giovanni.vezzoli@unimib.it (G. Vezzoli)

\begin{abstract}
The subequatorial Angolan continental margin offers excellent conditions to test textbook theories on the composition of passive-margin sediments generated in different climatic and tectonic regimes. We use here comprehensive petrographic, heavy-mineral, geochemical and zircongeochronology datasets on modern fluvial, beach, shelfal, and deep-marine sands and muds collected from hyperarid northern Namibia to hyperhumid Congo to investigate and assess: a) how faithfully sand mineralogy reflects the lithological and time structures of source rocks in a tectonically active rifted margin; b) in what climatic and geomorphological conditions the mark of
\end{abstract}


chemical weathering becomes strong and next overwhelming; and, c) to what extent the effect of weathering can be isolated from quartz dilution by recycling of older siliciclastic strata and other physical controls including hydraulic sorting and mechanical wear. A new refined classification of feldspatho-quartzose and quartzose sands and sandstones is proposed.

First-cycle quartzo-feldspathic to feldspar-rich feldspatho-quartzose sand eroded from mid-crustal granitoid gneisses of the Angola Block exposed in the dynamically uplifted Bié-Huila dome is deposited in arid southern Angola, whereas quartz-rich feldspatho-quartzose to quartzose sand characterizes the lower-relief, less deeply dissected, and more intensely weathered rifted margin of humid northern Angola. Pure quartzose, largely recycled sand is generated in the vast, low-lying hyperhumid continental interiors drained by the Congo River. The progressive relative increase of durable minerals toward the Equator results from three distinct processes acting in accord: active tectonic uplift in the arid south, and progressively stronger weathering coupled with more extensive recycling in the humid north. The quartz/feldspar ratio increases and the plagioclase/feldspar ratio decreases rapidly in first-cycle sand generated farther inland in the Catumbela catchment, reflecting stronger weathering in wet interior highlands. Discriminating weathering from recycling control is difficult in northern Angola. Although textural features including deep etch pits even on relatively resistant minerals such as quartz and microcline or rounded outline and abraded overgrowths provide valuable independent information, recycling remains as a most elusive problem in provenance analysis of terrigenous sediments.

Keywords: Provenance analysis; Classification of feldspatho-quartzose sands; Raman-counting of deep-water silt; U-Pb zircon geochronology; Weathering of detrital minerals; Quartzarenite problem. 
"The present is the key to the past"

Archibald Geikie, The Founders of Geology

"From this gateway Moment a long eternal lane stretches backward: behind us lies an eternity. Must not what ever can happen, already have happened, been done, passed by before? And if everything has already been here before, what do you think of this moment, dwarf?"

Friedrich Nietzsche, Thus Spoke Zarathustra, On the Vision and the Riddle.

\section{Introduction}

1 Paleotectonic and paleoclimatic interpretations based on the composition of ancient sandstone suites

2 often rely on assumptions seldom verified in a sufficient number of modern case studies (Basu,

3 1985). The effect of chemical weathering in the weathering-prone climatic conditions found in

4 equatorial and subequatorial settings has been investigated extensively in South America

5 (Franzinelli and Potter, 1983; Johnsson et al., 1988, 1991; Potter, 1994), but less so in Africa (e.g.

6 Dupré et al., 1996; Schneider et al., 2016), which is an excellent location in which to test classic

7 textbook theories on passive-margin sediments generated at diverse latitudes and in diverse climatic

8 and tectonic regimes.

9 Sand deposited along passive margins is generally viewed as characterized by feldspatho-quartzose composition, with quartz/feldspar ratio controlled on the one hand by tectonic activity favoring

rapid erosion of exhumed basement rocks and preservation of less stable detrital components, and on the other hand by chemical weathering that determines instead their progressive alteration and final breakdown (Folk, 1980; Dickinson, 1985). Passive margins can be distinguished into volcanic (magma-rich) and magma-poor (Franke, 2013). Sediment sources in the latter are ancient crystalline basements exposed on rifted-margin shoulders and their cover strata including pre-rift, syn-rift and post-rift siliciclastic and carbonate rocks. Volcanic detritus derived from continental flood basalts and associated felsic products may be common and locally dominant in the former (Garzanti et al., 2014a).

Coastal Angola, located at subequatorial latitudes, is characterized by hyperarid climate in the south passing progressively northward to semiarid, humid, and eventually hyperhumid in the Congo (Fig. 
1). The geology of the Angolan rifted margin is relatively simple and homogeneous, with the Angola Block consisting of largely mid-Paleoproterozoic granitoid basement in the southern and central parts and the metamorphic West Congo Belt of Neoproterozoic age in the north. After Early Cretaceous rifting leading to the opening of the southern Atlantic Ocean, the region has undergone successive and also recent stages of dynamic uplift (Giresse et al., 1984; Hudec and Jackson, 2004; Al-Hajri et al., 2009; Guiraud et al., 2010; MacGregor, 2013; White, 2016; Green and Machado, 2017). Coastal Angola represents therefore an exceptionally suitable natural laboratory in which to investigate how the detrital signature of daughter sand may respond to the lithological and time structures (i.e., the diverse age patterns of source areas obtained by different geochronological methods) of parent rocks, and to assess to what extent sand mineralogy can be modified during the sedimentary cycle by chemical weathering as well as by diverse physical factors (i.e., mechanical breakdown, hydraulic sorting, and recycling).

This study illustrates an integrated petrographic, mineralogical, geochemical and geochronological dataset on modern sands collected along the entire Angolan continental margin, which complements data obtained with the same methods and following the same criteria during previous studies on sediment generation in southwestern Africa (Vermeesch et al., 2010; Garzanti et al., 2012a, 2014a, 2014b, 2014c, 2015, 2017; Dinis et al., 2016, 2017), to which the reader is referred as aspects specific to adjacent regions are concerned.

\section{The Angolan rifted margin}

\subsection{Basement rocks}

The oldest rocks of subequatorial Africa belong to the Archean to Paleoproterozoic Kalahari and Congo cratons, welded together by a series of orogenies including the major Namaqua arcaccretion and continent-collision event between $\sim 1.1$ and 1.05 Ga (De Waele et al., 2008; Jacobs et al., 2008). West Gondwana was finally amalgamated during the Neoproterozoic to Cambrian 
Damara ("Pan-African") orogeny (Gray et al., 2008; Heilbron et al., 2008; Vaughan and Pankhurst, 2008; Frimmel et al., 2011).

In western Africa, the Congo craton is represented by the Angola Block, the core of which consists of felsic Eburnean ( $2 \mathrm{Ga}$ ) plutonic and metamorphic rocks (Fig. 1D; De Carvalho et al., 2000; McCourt et al., 2013). Along its northeastern limit, Neoarchean granites, gneisses and migmatites occur together with gabbros, norites and charnockites (Liberian-Limpopo massifs; Delhal et al., 1976; De Carvalho et al., 2000). In southern Angola to northernmost Namibia, where it is represented by the Epupa metamorphic unit, the Angola Block is intruded by one of the largest anorthosite bodies on Earth, dated at 1.37-1.38 Ga and including norite and gabbro (Mayer et al., 2004; Drüppel et al., 2007).

The West Congo and Kaoko belts were formed during the Neoproterozoic-Cambrian orogeny and both display progressively increasing metamorphic grade from only mildly deformed Neoproterozoic foreland units in the east to medium-grade or even high-grade rocks in the west. The West Congo Belt, stretching from southwestern Gabon to northwestern Angola, comprises Paleoproterozoic basement gneisses intruded by $\sim 2 \mathrm{Ga}$ granites and thrust NE-ward onto a Neoproterozoic succession beginning with a thick volcano-sedimentary unit including a bimodal magmatic suite dated between 1.0 and $0.9 \mathrm{Ga}$ (Tack et al., 2001). The overlying West Congolian Group, only gently folded and unmetamorphosed in the east, includes siliciclastic strata with intercalated pillow-basalts and diamictites, capped by a stromatolite-bearing carbonate platform followed in turn by siliciclastic syn-orogenic to post-orogenic sediments (Frimmel et al., 2006). The Kaoko Belt, located at the southwestern tip of the Congo craton and representing the transpressive northern arm of the Damara orogen, comprises the Epupa Paleoproterozoic basement and an arc terrane with high-grade metasediments and granitoids close to the coast (Goscombe et al., 2003; Goscombe and Gray, 2007). 
Rifting and initial sea-floor spreading in the South Atlantic progressed northward during the Early Cretaceous (Moulin et al., 2010). Tectonic evolution was controlled by oceanic fracture zones extending through continental crust commonly along Precambrian structures and locally leaking mantle-derived magmas (Mohriak and Rosendhal, 2003). The conjugate Brazilian and African rifted margins were thus segmented into transform, oblique and normal-rifted tracts separated by transverse fault zones (Guiraud et al., 2010). Along the Angolan coast, Precambrian basement is non-conformably overlain by a several km-thick Lower Cretaceous to Neogene succession accumulated in distinct depocenters (Lower Congo, Inner and Outer Cuanza, Benguela, and Namibe basins) and subdivided into syn-rift continental deposits followed by evaporites and post-rift marine sediments (Hudec and Jackson, 2002; Chaboureau et al., 2013).

The up to $5 \mathrm{~km}$-thick pre-salt strata of Neocomian to Aptian age include feldspar-rich fluviolacustrine conglomerates, sandstones and shales, lacustrine carbonates, and interbedded lava flows and ash deposited during tectonic extension (Bate et al., 2001; Sabato-Ceraldi and Green, 2017). Salt deposits mostly consisting of massive halite were deposited at mid-Aptian times from north of the Walvis Ridge to Gabon. Some tens of m-thick onshore, evaporites reach up to $1.4 \mathrm{~km}$ offshore and overstep the underlying pre-salt wedge both landward and seaward, suggesting direct deposition onto oceanic crust formed close to sea-level (Marton et al., 2000). Halokynesis impacted greatly sedimentation at subsequent stages and determined the structural style of the Angolan passive margin (Fort et al., 2004). The post-salt succession is up to $5 \mathrm{~km}$-thick. Fully marine conditions returned in the Albian, with deposition of platform carbonates passing to deep-water mudstones offshore. Siliciclastic sedimentation, mainly confined to the Benguela and Namibe basins in the Albian (Quesne et al., 2009; Gindre-Chanu et al., 2015), became dominant in the Upper Cretaceous and Cenozoic (Séranne and Anka, 2005). Prograding clastic wedges and repeated erosional gaps in the coastal plain and shelf document several phases of inner-margin uplift during the Neogene (Jackson et al., 2005). In the vast Kalahari basin, stretching $\sim 2200 \mathrm{~km}$ in the hinterland from the Congo to South Africa, up to $450 \mathrm{~m}$-thick largely fluvial sediments were 
deposited possibly since the Late Cretaceous, and a huge sand sea was formed by eolian reworking during drier periods of the Plio-Pleistocene to early Holocene (Haddon and McCarthy, 2005).

\subsection{Syn-rift to post-rift volcanic rocks}

Syn-rift volcanism reaching climax around $132 \mathrm{Ma}$ is best represented by the Etendeka continental flood basalts and quartz latites of northern Namibia, situated landward of the Walvis Ridge (Renne et al., 1996; Ewart et al., 2004). The Angolan margin is instead mainly volcanic-poor (Séranne and Anka, 2005; Péron-Pinvidic et al., 2017), although Lower to Upper Cretaceous tholeiitic to alkaline bimodal volcanic products are found in several localities of the Namibe and Cuanza basins (Fig. 1D; Masse and Laurent, 2016). In the Namibe basin, tholeiitic basalts overlain by felsic stratoid flows and travertine rest unconformably on Precambrian basement or pre-rift Karoo sandstones, whereas basaltic flows overlying ammonite-bearing strata are dated as Santonian $(84.6 \pm 1.5 \mathrm{Ma}$; Alberti et al., 1992; Strganac et al. 2014; Gindre-Chanu et al., 2016). In the Sumbe area of central Angola, 100 m-thick tholeiitic lavas dated at $\sim 132 \mathrm{Ma}$ and altered pyroclastic rocks directly overlie the Precambrian basement, which is intruded by tholeiitic dykes subparallel to the coast. Sodic alkaline and transitional products dated at $\sim 91 \mathrm{Ma}$ are intercalated with Upper Cretaceous marine strata (Marzoli et al., 1999). Volcanism took place at the landward extension of the Cuanza seamount chain built on oceanic crust, which acted as a sedimentary barrier between the Benguela and Cuanza basins (Hudec and Jackson, 2002). Reactivation of deep lithospheric faults during Early Cretaceous rifting was associated with kimberlite and carbonatite magmatism concentrated along the 50-90 km-wide Lucapa tectonic corridor extending to the NE of the Namibe basin (CominChiaramonti et al., 2011; Castillo-Oliver et al., 2016).

\subsection{Climatic gradients and weathering conditions}

Angola is situated between $\sim 17^{\circ} 30^{\prime} \mathrm{S}$ and $\sim 6^{\circ} \mathrm{S}$, roughly at the same distance from the Tropic of Capricorn and the Equator and thus right in the middle of the subequatorial belt. The coastal zone, stretching N/S for $\sim 1450 \mathrm{~km}$ between the mouths of the Cunene and Congo rivers, experiences a 
latitudinal climatic gradient. Conditions change progressively from hot desert in coastal Namibia and southern Angola to hot semi-arid in the coastal Benguela region, and next to tropical savanna northward toward the humid Congo (Fig. 1C). The aridity of the southern region results from the influence of quasi-stationary anticyclonic conditions on most austral Africa coupled with the Benguela upwelling system responsible for low sea-surface temperatures and low-humidity southerly winds (Shannon and Nelson, 1996; Lancaster, 2002). The cold and nutrient-rich Benguela Current flows equatorward all along the Atlantic coast of southern Africa as the eastern branch of the subtropical gyre, until it converges with the warm and nutrient-poor southward-flowing Angola Current representing the eastern part of the Angola gyre (Lass and Mohrholz, 2008). Aridity decreases progressively north of the Angola-Benguela Front, located between $20^{\circ} \mathrm{S}$ and $14^{\circ} \mathrm{S}$ and moving northward in July-September and southward in January-March (Kostianoy and Lutjeharms, 1999; Hardman-Mountford et al., 2003). Along the coast, average annual precipitation varies from $<100 \mathrm{~mm}$ in the hyperarid south, where rainfall is rare and exceeded by water generated from condensation and fog (locally called "cassimbo"), to 400-600 mm north of Luanda. Rainfall increases more rapidly up to $\sim 1500 \mathrm{~mm}$ inland, where climate becomes humid subtropical or temperate-highland tropical with dry winters at high elevation. The isohyets trend approximately $\mathrm{E} / \mathrm{W}$ in the continental interior, where the latitudinal gradient is much stronger than along the coast (Fig. 1C).

Average annual temperatures vary little through much of coastal Angola, from $21-27^{\circ} \mathrm{C}$ north of $10^{\circ} \mathrm{S}$ to $20-24^{\circ} \mathrm{C}$ in the south, and drop to $\sim 15^{\circ} \mathrm{C}$ only in the Moçamedes Desert and in the highlands, which reach 2619 m a.s.l. at Mount Moco in the headwaters of the Balombo River (Diniz, 2006). The warm rainy season, longer at lower latitudes and in the highlands, starts between September and November and lasts until March to May depending on the region, with rainfall peak in February to March. Weak southerly to south-westerly winds prevail all over the year in the coastal region, where north of Namibe eolian sand transport becomes negligible.

Different weathering conditions controlled by the two broadly perpendicular N/S and E/W climatic gradients, and consequently different intensities of pedogenic processes, are reflected by clay- 
153

154

155

156

157

158

159

160

161

162

163

164

165

166

167

168

169

170

171

172

mineral assemblages and chemical-weathering proxies in river muds (Dinis et al., 2017). Kaolinite, supplied in abundance to the coast by most major Angolan rivers, is largely generated in the wet hinterland, and particularly on ancient flat surfaces decreasing in elevation westward and separated by escarpments of variable relief. Expansive clays, instead, are mainly formed in Meso-Cenozoic basins located in dryer areas along the coast. As a consequence, the smectite/kaolinite ratio is $\sim 1$ in arid southern Angola, decreases rapidly in the semiarid Benguela region, and is very low in the more humid north with the exception of muds carried by the Longa, Cuanza, and Bengo rivers cutting across the Meso-Cenozoic Cuanza basin in their lower course.

\subsection{River systems}

Apart for the Congo $\left(4,000,000 \mathrm{~km}^{2}\right.$, length $\left.4700 \mathrm{~km}\right)$, the largest Angolan rivers draining into the Atlantic Ocean are the Cunene $\left(\sim 110,000 \mathrm{~km}^{2}, \sim 1050 \mathrm{~km}\right)$ and the Cuanza $\left(\sim 150,000 \mathrm{~km}^{2}, \sim 960\right.$ $\mathrm{km})$. The Longa, Queve, Curoca, and Mebridege are $~ 300 \mathrm{~km}$-long and drain $\sim 20,000 \mathrm{~km}^{2}$ each; the Catumbela and Coporolo are 200-250 km-long and drain $\sim 15,000 \mathrm{~km}^{2}$ (Fig. 1B). Of similar length are the Loge, Dande, Bengo, and Bero, which also drain more than $10,000 \mathrm{~km}^{2}$ each, and another dozen ephemeral rivers draining between 2000 and $7000 \mathrm{~km}^{2}$. Three major rivers are sourced in the very same area between the cities of Huambo and Katchiungo at $\sim 1800 \mathrm{~m}$ a.s.l. on the dynamically uplifted Bié-Huila dome: the Queve draining northward, the Cunene draining southward, and the Cubango branch of the Okavango draining southeastwards across the Kalahari (Fig. 1). The Cuanza is instead sourced in the Kalahari and flows northwards around the Angola Block. These river courses may have formed soon after opening of the South Atlantic, although the modern configuration with radial drainage of the Biè-Huila dome was acquired much more recently in response to dynamic uplift, as documented by morphometric analysis (Pritchard et al., 2009; Anka et al. 2010). Few rivers have regular concave equilibrium profiles. Most display youthful, staircase profiles with long flat segments separated by very steep tracts, reflecting the stepped remnant plateaus typical of the African landscape (Diniz, 2006). Convex profiles indicative of 
179

retrogressive erosion characterize rivers draining the Kalahari plateau or coastal uplifts (Leturmy et al., 2003).

Sizeable dams or weirs were built on the Cunene (Matala 1954, Gove 1975, Calueque 1976, Ruacana 1980), Cuanza (Cambambe 1963, Capanda 2004), and Catumbela rivers (Lomaum 1965). Several were abandoned, damaged severely or destroyed during the civil war (1975-2002), and have been rehabilitated recenty. Others include the Mabubas Dam on the Dande and the Kiminha Dam on the Bengo. Based on sediment volumes stored in the Cambambe reservoir and measured in the late Eighties, the Cuanza solid load amounts to $620 \pm 10010^{3}$ ton/a (43\% mostly fine sand with some gravel, $44 \%$ coarse silt, $13 \%$ clay to medium silt; Holisticos, 2012). This corresponds to low sediment yields and erosion rates $\left(4 \pm 1 \mathrm{ton} / \mathrm{km}^{2} \mathrm{a},<0.002 \mathrm{~mm} / \mathrm{a}\right)$.

\subsection{Coastal geomorphology and marine processes}

The Atlantic coast of Angola is wave-dominated and microtidal (maximum significant wave height $\sim 1.75 \mathrm{~m}$; mean tide amplitude $\sim 1 \mathrm{~m}$ ). A powerful southerly swell, originated by persistent stormy winds far away in the Southern Ocean between $40^{\circ} \mathrm{S}$ and $60^{\circ} \mathrm{S}$, causes periodic high-energy wave events called "calema" and extensive northward sand transport all along the Atlantic shore of southern Africa. Scarcely affected by either local winds or the Benguela Current, the direction of littoral transport is controlled by the oblique incidence of the wave front to the coast, which determines the asymmetry of deltas and the formation of sand spits in proximity of coastal reentrants were waves are refracted and sand accumulates offshore (Guilcher et al., 1974).

Shelf topography and width exert a major role on sediment transport. The southern Angola obliquerifted to transform-rifted margin has a narrow coastal plain delimited offshore by a steep continental slope and inland by a high-elevation escarpment with relief up to $1.5 \mathrm{~km}$ (Feio, 1981; Lopes et al., 2016). The normal-rifted margin of northern Angola is much wider and has gentler continental slope and hinterland relief without a major escarpment. Such a marked topographic difference reflects both the tectonic structure inherited from Lower Cretaceous rifting and prominent recent 
uplift of the Bié-Huila dome in southwestern Angola (Moulin et al., 2005; Pritchard et al., 2009; Guiraud et al., 2010).

The continental shelf, $25-30 \mathrm{~km}$-wide to the $-150 \mathrm{~m}$ isobath offshore of the Cunene mouth, narrows rapidly north of the Baia dos Tigres spit to $<10 \mathrm{~km}$ along most of the coast from Tombua to Benguela. Shelf width is reduced to $\sim 1 \mathrm{~km}$ at the head of submarine canyons offshore of the Curoca and Bero river mouths, which intercept littoral drifting sand thus terminating the $\sim 1800$ km-long Orange littoral cell (Garzanti et al., 2017), as well as between north of the Coporolo mouth and the Baia Farta spit. The shelf widens again to $\geq 20 \mathrm{~km}$ north of Benguela, and widens further north of Luanda to $\sim 70 \mathrm{~km}$ south of the Congo river mouth.

\section{Sampling and analytical methods}

All along the coast of Angola, in June 2015 we have sampled 26 fluvial sand bars exposed at lowwater level from all major rivers draining into the Atlantic Ocean, 43 beaches, and 2 dunes. Sediment samples collected offshore of the Congo, Tapado, Balombo, Coporolo and Cunene mouths as well as south of the Cuanza seamount chain and on the Walvis Ridge at water depths between -30 and $-3000 \mathrm{~m}$ b.s.l. were retrieved from the MARUM repository in Bremen. Offshore samples were collected a few dm below seafloor during Meteor expeditions M6/6, M20/2, and M41/1 (Wefer et al, 1988; Schulz et al., 1992, 1998), or represent the upper meters of cores drilled during DSDP Leg 40 and ODP Leg 175 (Fig. 1A). Numerous other river, beach, and dune samples were collected in various years along the coast of Namibia, in the Cunene catchment and southern Moçamedes Desert, in central Angola, in the terminal tract of the Congo River, and in the Republic of Congo. This extensive set of 136 samples overall allowed us to monitor detrital signatures in response to changing lithology and age of source terranes along the Atlantic passive margin of southern Africa, as well as compositional trends controlled not only by latitudinal climatic zonation from hyperarid Namibia to hyperhumid Congo but also by the sharp inland rainfall gradient. Full information on sampling sites is provided in Appendix Table A1 and Google Earth ${ }^{\mathrm{TM}}$ file 
Angolamargin.kmz. Main parameters characterizing river catchments are given in Appendix Table A2.

\subsection{Petrography and heavy minerals}

Petrographic composition of each sand sample was determined by counting 400 to 450 points in thin section by the Gazzi-Dickinson method (Ingersoll et al., 1984). Sands are classified by their main components exceeding 10\%QFL (e.g., in a feldspatho-quartzose sand Q > F > 10\%QFL > L; Garzanti, 2016). An adjective reflecting the dominant rock-fragment type may be added freely (e.g., plutoniclastic). Among feldspatho-quartzose sands, feldspar-rich $(\mathrm{Q} / \mathrm{F}<2$; plagioclase-rich if plagioclase/K-feldspar > 2, K-feldspar-rich if K-feldspar/plagioclase > 2) and quartz-rich (Q/F > 4) compositions are here formally distinguished (Fig. 2A). Cross-hatched microcline and untwinned K-feldspar including perthite are called for simplicity microcline and orthoclase throughout the text. Metamorphic grains were classified by protolith composition and metamorphic rank; average rank for each sample was expressed by the Metamorphic Indices MI and MI*, ranging respectively from 0 (detritus from sedimentary and volcanic rocks) and 100 (detritus from very low-grade metamorphic rocks) to 500 (detritus from high-grade metamorphic rocks; Garzanti and Vezzoli 2003).

From the widest possible size-range obtained by wet sieving (mostly $<500 \mu \mathrm{m}$ for clean beach and dune sands and $15-500 \mu \mathrm{m}$ for positively skewed river sands), heavy minerals were separated by centrifuging in Na-polytungstate $\left(2.90 \mathrm{~g} / \mathrm{cm}^{3}\right)$ and recovered by partial freezing with liquid nitrogen; 200 to 250 transparent heavy minerals were point-counted at suitable regular spacing on grain mounts to obtain real volume percentages (Galehouse, 1971). On finer-grained offshore samples, heavy-mineral analyses were carried out by Raman point-counting (Andò et al., 2011) on

the $>5 \mu \mathrm{m}$ (silty clays) or $>15 \mu \mathrm{m}$ fraction (sandy silts and silty sands) obtained by wet sieving. The ZTR index, expressing the "chemical durability" of the suite (Garzanti, 2017), is the sum of zircon, tourmaline and rutile over total transparent heavy minerals (Hubert, 1962). The hornblende colour index (HCI) varies from 0 in detritus from greenschist-facies and lowermost amphibolite- 
facies rocks to 100 in detritus from granulite-facies rocks (Andò et al., 2014). Heavy-mineral concentration, calculated as the volume percentage of total (HMC) and transparent (tHMC) heavy minerals, ranges from extremely poor $(\mathrm{HMC}<0.1)$, poor $(0.5 \leq \mathrm{HMC}<1)$ and moderately poor $(1$ $\leq \mathrm{HMC}<2)$, to rich $(5 \leq \mathrm{HMC}<10)$, very rich $(10 \leq \mathrm{HMC}<20)$ and extremely rich $(20 \leq \mathrm{HMC}<$ 50); placer sands are defined by HMC $\geq 50$. The Source Rock Density (SRD) index, defined as the weighted average density of extrabasinal terrigenous grains, was used to detect hydraulic-controlled concentration of denser minerals (Garzanti and Andò, 2007). In all analysed samples corrosion features were assessed systematically by three different operators on $\sim 25,000$ transparent heavymineral grains, following the classification of surface textures in Andó et al. (2012). Significant minerals are listed in order of abundance throughout the text. Key compositional parameters are summarized in Table 1. The complete petrographic, heavy-mineral and surface-texture datasets are provided in Appendix Tables A3, A4, and A5.

\subsection{Geochemistry}

Chemical analyses of 26 river, 23 beach and 2 dune sands were carried out at ACME Laboratories (Vancouver) mostly on a quartered aliquot of the 63-2000 $\mu \mathrm{m}$ class obtained by wet-sieving. Following a lithium metaborate/tetraborate fusion and nitric acid digestion, major oxides and several minor elements were determined by ICP-ES and trace elements by ICP-MS (see Appendix A for specific information on the adopted analytical protocol).

To estimate weathering we used several chemical indices, including the Chemical Index of Alteration $\left[\mathrm{CIA}=100 \cdot \mathrm{A}_{2} \mathrm{O}_{3} /\left(\mathrm{A}_{2} \mathrm{O}_{3}+\mathrm{CaO}+\mathrm{Na}_{2} \mathrm{O}+\mathrm{K}_{2} \mathrm{O}\right)\right.$; Nesbitt and Young, 1982] and the Weathering Index [WIP $=100 \cdot\left(\mathrm{CaO} / 0.7+2 \mathrm{Na}_{2} \mathrm{O} / 0.35+2 \mathrm{~K}_{2} \mathrm{O} / 0.25+\mathrm{MgO} / 0.9\right) ;$ Parker, 1970], calculated using molecular proportions of mobile alkali and alkaline earth metals corrected for $\mathrm{CaO}$ in apatite. Instead of correcting the CIA for $\mathrm{CaO}$ in carbonates based on mineralogical data, which may result in significant error (Garzanti and Resentini, 2016), we preferred to use the CIX, a simple modification of the CIA not considering $\mathrm{CaO}\left[\mathrm{CIX}=100 \cdot \mathrm{A}_{2} \mathrm{O}_{3} /\left(\mathrm{Al}_{2} \mathrm{O}_{3}+\mathrm{Na}_{2} \mathrm{O}+\mathrm{K} 2 \mathrm{O}\right)\right.$; 
comparing its concentration to that of non-mobile $\mathrm{Al}$ in our samples and in the Upper Continental Crust standard: $\alpha^{\mathrm{Al}} \mathrm{E}=(\mathrm{Al} / \mathrm{E})_{\text {sample }} /(\mathrm{Al} / \mathrm{E})_{\mathrm{UCC}}$ (Garzanti et al., 2013, modified after $\alpha$ values of Gaillardet et al. 1999; UCC standard after Taylor and McLennan, 1995; Rudnick and Gao, 2003). Rare earth elements (REE) were normalized to CI carbonaceous chondrites (McDonough and Sun 1995). Main weathering indices are shown in Table 1. The complete geochemical dataset is provided in Appendix Table A6.

\subsection{Detrital geochronology}

Detrital zircons were identified by Automated Phase Mapping with a QEMSCAN ${ }^{\circledR}$ WellSite $^{\text {TM }}$ instrument (Vermeesch et al., 2017) on the heavy-mineral separates (mostly $<500$ or $15-500 \mu \mathrm{m}$ class) of 50 selected samples. U-Pb ages were determined at the London Geochronology Centre using an Agilent 7700x LA-ICP-MS (laser ablation-inductively coupled plasma-mass spectrometry) system, employing a NWR193 Excimer Laser operated at $11 \mathrm{~Hz}$ with a $20 \mu \mathrm{m}$ spot size and 2.5-3.0 $\mathrm{J} / \mathrm{cm}^{2}$ fluence.

No cathodo-luminescence (CL) imaging was done, and the laser spot was always placed "blindly" in the interior of zircon grains. Textural information acquired by CL-imaging can be useful for detrital geochronology. For example, the presence of oscillatory zoning in zircon may indicate an igneous origin, whereas the presence of complex patterns indicates a multi-phase growth history. This knowledge can be very useful for studies whose aim is to identify specific igneous or metamorphic sediment sources. But in other studies the textural information provided by CL-imaging creates additional challenges. If one's main goal is to compare different age distributions with each other like fingerprints, then it is important that all samples are treated in exactly the same way. The availability of textural information makes it more difficult to decide which part of a grain should be analysed: core, rim, or both? In such cases, it is better to always place the ablation spots in the middle of the grain. A "blind dating strategy" is the easiest way to ensure consistency between samples. Data reduction was peformed using GLITTER 4.4.2 software (Griffin et al., 2008). We used ${ }^{206} \mathrm{~Pb} /{ }^{238} \mathrm{U}$ and ${ }^{207} \mathrm{~Pb} /{ }^{206} \mathrm{~Pb}$ ages for zircons younger and older than $1100 \mathrm{Ma}$, respectively. No 
common $\mathrm{Pb}$ correction was applied. Grains with $>+5 /-15 \%$ age discordance were discarded, and 2967 concordant ages were obtained overall. The complete geochronological dataset is provided in Appendix B.

\section{Detrital signatures of river sands}

\subsection{Cunene River}

The Cunene River, sourced in Bié-Huila highlands, flows across the fossil Kalahari dunefield and once drained towards the Etosha Pan of northern Namibia as the Okavango River drains today into the Makgadikgadi Pan of Botswana (Fig. 1B). Captured only recently by a coastal stream (Haddon and McCarthy, 2005), the lower Cunene cuts deeply across the rifted-margin shoulder where the

Paleoproterozoic Epupa basement, the Mesoproterozoic Cunene anorthosite, and finally the Kaoko northern branch of the Damara orogen are exposed (Becker et al., 2006). In the terminal tract the river marks the northern limit of the Cunene coastal dunefield and eventually reaches the Atlantic Ocean south of the Moçamedes Desert. Sand mineralogy changes repeatedly downstream (Fig. 2E), which implies higher erosion rates in the lower tract than in the upper to middle course. At Ruacana Falls at the end of the middle course, sand composition is quartz-rich feldspatho-quartzose with dominant monocrystalline quartz, orthoclase $>$ plagioclase $\geq$ microcline and a poor amphiboleepidote heavy-mineral suite. Quartz grains recycled from Kalahari dunes (e.g., supplied by the Caculuvar tributary and Mucope subtributary) are about twice as abundant as first-cycle detritus from basement rocks. At Epupa Falls, sand is plagioclase-rich feldspatho-quartzose and markedly enriched in polycrystalline quartz, clinopyroxene and hypersthene, revealing dominant supply from crystalline basement including the Cunene anorthosite and associated mafic rocks (e.g., drained by the Omuhongo tributary; Fig. 3). Sand composition changes again in the terminal tract because of extensive mixing with dune sand windblown from the coast and mostly derived ultralong-distance from the Orange River (Garzanti et al., 2014c). In Cunene sand at Epupa Falls, zircon-age spectra 
are unimodal with broad slightly asymmetric Mesoproterozoic peak centered at $\sim 1.4 \mathrm{Ga}$ and most ages ranging between 1 and $2 \mathrm{Ga}$.

\subsection{Rivers of southern Angola (Curoca to Cangala)}

The Curoca River marks the northern boundary of the Moçamedes coastal dunefield, and in its terminal tract - as in the terminal tract of the Cunene - mixing with windblown sand is so extensive that composition becomes indistinguishable from littoral sand largely derived ultralongdistance from the Orange River (Fig. 2E). A fossil dune collected upstream of the mouth contains more K-feldspar and less heavy minerals including mainly staurolite and tourmaline, and no pyroxene. Zircon-age spectra in both Curoca mouth and fossil-dune samples display a polymodal distribution undistinguishable from that of Moçamedes desert sand, with the Damaran (Cambrianlate Neoproterozoic) and Namaqua (late Mesoproterozoic) clusters typical of Orange sand associated with subordinate Eburnean (late Paleoproterozoic) ages.

All rivers to the north drain the Angola Block, consisting of Eburnean granitoid rocks and subordinate metasediments with an overlying volcano-sedimentary sequence and younger bimodal magmatic products exposed in the "coastal polyorogenic belt" (De Carvalho et al., 2000; Pereira et al., 2011; Ernst et al., 2013). Sand composition ranges from quartzo-feldspathic to feldspar-rich feldspatho-quartzose with plagioclase $>$ orthoclase $>$ microcline (Fig. 2B). Granitoid rock fragments and polycrystalline quartz are very common, associated with a few metamorphic (quartz-mica, quartz-epidote, low-grade metabasite, rare schist, and amphibolite) and rare sedimentary (sparite and quartz siltstone) lithics. Muscovite and biotite occur sporadically. Moderately rich heavymineral suites range from amphibole-epidote in Bero and Giraul sands in the south, to epidoteamphibole in the north (Fig. 3). Clinopyroxene and hypersthene in Bero sand may be supplied by the Cunene intrusive complex drained in the headwaters. Provenance from chiefly granitoid rocks is reflected by very strong depletion in $\mathrm{Mg}$ and enrichment in $\mathrm{K}, \mathrm{Rb}$, and especially $\mathrm{Ba}$ relative to the UCC standard $\left(\alpha^{\mathrm{Al}} \mathrm{Mg} 8 \pm 2, \alpha^{\mathrm{Al}} \mathrm{K} 0.6 \pm 0.1, \alpha^{\mathrm{Al}} \mathrm{Ba} 0.4 \pm 0.0\right.$ for Giraul, Bentiaba, Inamangando, and Cangala sands, Bero sand being slightly more mafic) (Fig. 4E). The Eu anomaly is only slightly 
negative $\left(\mathrm{Eu}^{*} 0.88 \pm 0.06\right)$. Bero sand yielded few Mesoproterozoic zircon ages, whereas spectra in Giraul and Inamangando sands are unimodal with peak centered around 2 Ga (Fig. 5).

\subsection{Rivers of southern central Angola (Coporolo to Catumbela)}

Composition ranges from quartzo-feldspathic (Cavaco sand) to feldspatho-quartzose (Catumbela sand) with plagioclase $\geq$ microcline $\geq$ orthoclase (Fig. 2B). Common granitoid and metaigneous rock fragments occur. Biotite prevails over muscovite. Heavy-mineral suites are moderately poor and epidote-dominated with amphibole in Coporolo and Cavaco sands. A richer epidote-amphiboleclinopyroxene suite with minor zircon and olivine characterizes Catumbela sand. Mafic igneous detritus in the Catumbela catchment is supplied by the lowermost-course Capilongo tributary draining gabbroic rocks of possible Mesoproterozoic age intruded in the "coastal polyorogenic belt" (Ernst et al., 2013) (Fig. 3). Geochemical signatures are similar to river sands of southern Angola but somewhat depleted in alkali and alkaline-earth metals. Zircon-age spectra are unimodal with sharp peak centered around 2 Ga (Fig. 5).

\subsection{Rivers of northern central Angola (Culango to Longa)}

The quartz/feldspar $(\mathrm{Q} / \mathrm{F})$ ratio increases progressively northward, composition ranging from feldspar-rich feldspatho-quartzose in the south to quartz-rich feldspato-quartzose in Longa sand (Fig. 2B,D). K-feldspar mainly prevails over plagioclase. Granitoid and a few metamorphic rock fragments occur. Limestone grains with marine fossils (echinoderm plates), and a few felsic volcanic grains are present in Longa sand, where monocrystalline quartz locally showing rounded outline or abraded overgrowths is dominant. Quicombo sand includes a few carbonate grains. Biotite prevails over muscovite. Poor to moderately rich, epidote-dominated to epidote $\approx$ amphibole suites include zircon. Cambongo sand contains a few mafic volcanic and clinopyroxene grains. Silica concentration is highest in Longa sand, with consequent dilution of most other elements. Zircon-age spectra are unimodal with sharp peak centered around 2 Ga (Fig. 5). Late Neoarchean to early Paleoproterozoic ages are represented in Queve sand. A few zircon grains with Early 
393 394 395 396 397 398 399 400 401 402 403 404 405 406 407 408

Cretaceous age occur in Quicombo sand, indicating additional supply from local syn-rift volcanic rocks.

\subsection{Rivers of northern Angola (Cuanza to Luculu)}

Composition is mainly quartz-rich feldspatho-quartzose with orthoclase + microcline $\geq$ plagioclase. Lifune, Mebridege, and Luculu sands are quartzose (Fig. 2B,D). Monocrystalline quartz is dominant in most samples, with well rounded grains most common in Cuanza, Bengo, and Luculu sands. Granitoid and metasedimentary rock fragments occur. Micas (muscovite > biotite) and medium-rank schist and quartz-mica lithics are most common in Dande sand. Quartz-siltstone to metasiltstone/metasandstone rock fragments are associated with quartz displaying abraded overgrowths or subrounded outline in Mebridege sand. Micrite to sparite grains are most common in Bengo sand and occur in Cuanza and Dande sand, where they may contain Cenozoic planktonic foraminifera. Very poor to rich heavy-mineral suites include mainly amphibole, epidote, garnet, and kyanite (ZTR $6 \pm 5$ ). River sands are progressively enriched northward in $\mathrm{SiO}_{2}$, with stronger and stronger dilution of most other elements. Zircon-age spectra display a peak around $2 \mathrm{Ga}$ and ages ranging mostly between $\sim 0.5$ and $\sim 3 \mathrm{Ga}$. Loge sand yielded a sharper unimodal Eburnean peak. Luculu sand yielded $\sim 10 \%$ of zircon grains with mid-Permian to mid-Triassic ages, which occur rarely in Cuanza and Bengo sands as well (Fig. 5).

\subsection{Rivers of the Congo}

Sands are dominated by subrounded to well rounded monocrystalline quartz; $\mathrm{SiO}_{2}$ reaches above 98\%. The Congo River carries to the mouth a few K-feldspar (orthoclase > microcline) and quartzose siltstone grains (Fig. 2D). The very poor heavy-mineral suite includes zircon, tourmaline, epidote, staurolite, kyanite, and minor rutile, amphibole, garnet, sillimanite, and andalusite (ZTR 51 \pm 16 ). Sands in the Republic of Congo to the north also contain a few quartzose siltstone grains and very poor suites dominated by zircon and tourmaline, with rutile, staurolite, kyanite, epidote, and garnet (ZTR $74 \pm 4)$. 


\section{Detrital signatures of coastal and offshore sediments}

423

424

425

426

\subsection{The Orange littoral cell}

Dune and beach sands between the Cunene mouth and south of Namibe are feldspatho-quartzose with lathwork volcanic rock fragments and moderately poor to extremely rich garnetclinopyroxene-epidote-amphibole suites including hypersthene and staurolite. Higher $\mathrm{Fe}, \mathrm{Mg}, \mathrm{Ca}$, Ti, P, Mn, Sc, Y, HREE, V, Cr, Co, and Ni than most other Angolan sands reflect the presence of common volcanic rocks fragments, pyroxene, and garnet. Zircon-age spectra show broad Cambrian/late Neoproterozoic, late Mesoproterozoic, and late Paleoproterozoic peaks, with a few younger (as young as Early Cretaceous) and older ages (as old as late Neoarchean; Fig. 5). Such petrographic, mineralogical, geochemical, and geochronological fingerprints resemble closely those of the Skeleton Coast Erg, pointing to ultralong-distance littoral transport from the Orange mouth with subordinate contributions from the Cunene River and ephemeral rivers draining the Damara orogen in Namibia (Garzanti et al., 2014c, 2017).

Sediments collected on the Walvis Ridge and offshore of the Cunene mouth are dominated by planktonic foraminifers and green glaucony grains, respectively (Fig. 6). The sandy-silt to silty-sand feldspatho-quartzose terrigenous fraction contains mafic volcanic rock fragments and a rich, clinopyroxene-dominated heavy-mineral suite with subordinate epidote, amphibole and garnet, indicating provenance mostly from the Orange mouth. Deep-sea silty clays offshore of Baia dos Tigres contain diatom tests and siliceous sponge spicules with minor radiolaria, silicoflagellates, glaucony, plant debris, and organic matter. The subordinate feldspar-rich feldspatho-quartzose terrigenous fraction yielded either the same clinopyroxene-dominated suite as Walvis Ridge and offshore Cunene samples, or a clinopyroxene-epidote-amphibole-garnet suite comparing closely with beaches and dunes of the southernmost Moçamedes Desert, thus revealing additional contribution from the Cunene River. 


\subsection{From Namibe beach to Coporolo mouth}

Beaches in the oblique Namibe rifted-margin segment bear the same feldspar-rich quartzofeldspathic composition and epidote-amphibole suites of local river sand, reflecting dominant supply from largely granitoid rocks exposed in adjacent Angolan highlands. Chemical composition is also similar, with higher $\mathrm{Fe}, \mathrm{Mg}, \mathrm{Ti}, \mathrm{P}, \mathrm{Mn}, \mathrm{Sc}, \mathrm{U}, \mathrm{V}, \mathrm{Cr}, \mathrm{Co}, \mathrm{Ni}$, and $\mathrm{Cu}$ in Namibe beach reflecting the abundance of heavy minerals including pyroxenes fed from the Bero River. Zirconage spectra are mostly unimodal with peak centered around 2 Ga (Fig. 5). Mesoproterozic ages are significant in Namibe beach. In Equimina beach, 22\% of zircon grains yielded ages between 84 and $104 \mathrm{Ma}$, indicating provenance from mid-Cretaceous trachytic lavas exposed locally (Neto, 1960).

Supply from Meso-Cenozoic strata of the Namibe basin is revealed in Chapeu Armado beach by microcline $\approx$ plagioclase, occurrence of a few carbonate and mafic volcanic lithics, and poor suites with common durable heavy minerals (ZTR 24). Carbonate, quartz-siltstone, and basaltic grains occur also at Mariquita and Bentiaba beaches. Beach sand is derived dominantly from basement rocks in the north where the Namibe basin tapers out, as documented by abundant feldspar, metabasite rock fragments and up to very rich epidote-amphibole suites, although a few carbonate rock fragments also occur. Presence of carbonate grains is reflected in locally high $\mathrm{CaO}$ and LOI (e.g., Baia Binga beach). Local differences in sand composition along this coastal stretch, where the shelf width is reduced to only some kilometers thus limiting the possibility of longshore sand drift, indicate that pocket beaches are largely independent sediment systems fed from the associated stream and coastal cliffs.

\subsection{The Coporolo and Catumbela littoral cells}

The perennial Coporolo and Catumbela Rivers represent the major source of beach sand along the Benguela transform rifted-margin sement (Dinis et al., 2016). Beaches north of the Coporolo mouth display the same feldspar-rich feldspatho-quartzose signature with moderately poor to moderately rich epidote-dominated suites with amphibole as Coporolo river sand. A few carbonate and quartzbearing siltstone and sandstone grains are however added along the coast, and quartz increases in 
474

475

476

477

478

479

480

481

482

483

484

485

486

487

488

489

490

491

492

493

494

495

496

497

the Baia Farta sand spit indicating additional supply from local streams and coastal cliffs. The shelf is very narrow offshore of the Baia Farta promontory, where a submarine canyon may capture longshore-drifting sand thus hampering northward elongation of the spit. The silty clay collected in the deep sea is quartzo-feldspathic with the same epidote-dominated suite as beach sand in the Coporolo cell. North of Benguela the continental shelf widens again to $\sim 25 \mathrm{~km}$, and northward littoral drift is renewed. Beach sand between the Cavaco and Catumbela mouths is nearly as feldspar-rich as Cavaco river sand. Sand with the same feldspatho-quartzose signature as Catumbela river sand with a rich epidote-dominated suite including amphibole and clinopyroxene is carried northward of the strongly asymmetric Catumbela delta to build prograding beach ridges culminating in the $5 \mathrm{~km}$-long Lobito spit. Zircon-age spectra are unimodal with sharp Eburnean peak. Beach sand north of Coporolo mouth yielded a few zircon grains with younger ages, one of which midCretaceous (Fig. 5).

\subsection{From Lobito to Cabo Ledo}

Beach sand along the oblique-rifted Cuanza margin segment is invariably feldspatho-quartzose, and thus richer in quartz than local river sands suggesting either additional supply from coastal cliffs or northward longhsore drift from the Catumbela mouth. The moderately poor to rich epidoteamphibole-clinopyroxene heavy-mineral suite may include rare olivine. Clinopyroxene, notably more abundant than in river sands, is derived from volcanic rocks best exposed in the Sumbe area (Marzoli et al., 1999) and/or longshore from the Catumbela mouth. Local enrichment in heavy minerals is revealed by higher Fe, Mg, Ti, Sc, REE, Zr, Hf, V, Nb, Ta, and $\mathrm{Cr}$ than in river sands.

Beach sand at Cabo Ledo, containing carbonate grains as reflected by locally high $\mathrm{CaO}$ and LOI, yielded a unimodal zircon-age spectrum with sharp Eburnean peak as beach sand at Porto Amboim. A few mid-Cretaceous ages confirm additional detritus from syn-rift igneous rocks along the coast. Silty sands collected offshore of the Tapado mouth include mostly benthic foraminifers, which become dominant beyond the shelfbreak (Fig. 6). The quartzo-feldspathic to feldspar-rich feldspatho-quartzose terrigenous fraction yielded a rich, epidote-dominated heavy-mineral suite 
501

with subordinate amphibole. Feldspar is more abundant than in beach sand and clinopyroxene minor, indicating provenance directly from the Balombo and/or Tapado river mouths rather than from longshore drifting sand. The silty clay collected in the deep sea south of the Cuanza seamounts (Fig. 1A), dominated by planktonic and subordinately benthic foraminifers, yielded a similar epidote-amphibole suite with no clinopyroxene.

\subsection{The Cuanza littoral cell}

Beach sand from the Cuanza mouth to Ilha de Luanda is quartz-rich feldspatho-quartzose with plagioclase $\approx$ microcline $\approx$ orthoclase. The poor to moderately rich epidote-amphiboleclinopyroxene heavy-mineral suite includes minor garnet, kyanite, staurolite, andalusite, and rare olivine. Feldspar is more common and ZTR indices lower than in Cuanza river sand. Clinopyroxene increases along the littoral cell where polycrystalline quartz is also more abundant, suggesting mixing with northward drifting sand along the broad littoral zone. Chemical data confirm significant differences between Cuanza river sand and the Mussulo and Ilha de Luanda spits, which have less Si, higher alkali and alkaline earth metals (and hence systematically lower weathering indices), lower $\mathrm{Zr}$ and $\mathrm{Hf}$, and much steeper REE patterns with no Eu anomaly.

\subsection{From Luanda to the Congo}

Beach sands along the orthogonal to oblique-rifted Congo-margin segment vary from mainly quartz-rich feldspatho-quartzose in the south to quartzose north of N'Zeto, with a progressive northward decrease in feldspar (orthoclase $\geq$ plagioclase $\geq$ microcline). The heavy-mineral concentration of epidote-amphibole-garnet-kyanite suites tends to decrease from mainly rich in the south to moderately rich and finally poor in the north, where staurolite becomes significant and zircon, tourmaline, and rutile increase (ZTR up to 13). Beach sand in the Republic of Congo consists almost entirely of commonly rounded monocrystalline quartz grains displaying deep etch pits, with only a few microcline grains and a very poor suite with zircon, rutile, tourmaline, 
staurolite, kyanite, and rare andalusite (ZTR 66). $\mathrm{SiO}_{2}$ increases progressively northward, reflecting increasing and finally overwhelming quartz dilution.

Zircon grains in Ambriz sand yielded a sharp unimodal Eburnean peak along with 5\% of Upper Permian ages. The Eburnean peak becomes broader north of the Loge mouth, where Permian ages also occur. The zircon-age spectrum is multimodal in beach sand south of the Congo mouth with Pan-African (0.5-0.7 Ga), Namaqua ( $1 \mathrm{Ga})$, Eburnean $(\sim 2 \mathrm{Ga})$ and Neoarchean $(2.5-2.7 \mathrm{Ga})$ clusters. A similar spectrum characterizes Congo estuary sand (Fig. 5).

Fine-grained quartzose sand collected on the inner shelf just south of the Congo mouth includes common brown goethite ooids (Fig. 6), a few plagioclase and K-feldspar grains, and a moderately rich heavy-mineral suite including epidote, garnet, amphibole, zircon, rutile, kyanite, minor andalusite, tourmaline, apatite and staurolite, indicating provenance form northward longshore drift rather than from the Congo River. Very fine-grained shelfal sediment north of the Congo mouth consists of brown pellets and foraminifers (Fig. 6).

\section{Provenance control on sand composition}

The geology of Angola includes two main domains, the Paleoproterozoic Angola Block with the prominent Mesoproterozoic Cunene intrusive complex in the south, and the Pan-African West Congo Belt in the north. The dual time structure of source rocks is best reflected by U-Pb ages of detrital zircons, characterized by unimodal spectra with sharp Eburnean peak at $\sim 2$ Ga from north of Namibe to south of the Cuanza mouth, and by multimodal distributions in northern Angola with Cambrian-Neoproterozoic, latest Mesoproterozoic, and Neoarchean clusters best defined in Congo estuary sand. The Mesoproterozoic peak with Eburnean shoulder displayed by detrital zircons in Cunene sand at Epupa Falls reflects contribution from the Cunene intrusive complex, documented as far north as Namibe beach fed by the Bero River. To the south, sharply different detrital modes, heavy-mineral suites, and zircon-age clusters characterize dunes and beaches of the Moçamedes Desert, documenting ultralong-distance provenance mainly from the Orange River. 
554

555

556

Detrital modes, heavy minerals, and concentration of chemical elements reflect local source-rock distribution as faithfully as zircon age-spectra only in dry southern Angola north of the Orange littoral cell, where abundance of feldspar and granitoid rock fragments among main framework grains and of epidote and amphibole among transparent heavy minerals indicate the Angola Block as the dominant source ("basement uplift subprovenance" of Dickinson, 1985; "dissected continental block subprovenance" of Garzanti, 2016). Metamorphic rock fragments of mainly medium to high rank (MI* $312 \pm 50$ ), epidote/hornblende ratio mostly $>1$ and dominantly blue/green amphiboles (HCI mostly $\leq 10$ ) point to mainly greenschist-facies to lower amphibolitefacies source rocks. Scarcity of garnet, lack of kyanite, andalusite and sillimanite, and only sporadic occurrence of metasedimentary rock fragments reflect predominance of granitoid and metagranitoid source rocks, as confirmed by geochemical signatures. Metabasite rock fragments and higher heavy-mineral concentration indicate more significant supply from mafic greenschist-facies rocks in beach sand from Lucira to the Coporolo mouth. Meso-Cenozoic strata and intercalated lavas of the Namibe basin supply minor amounts of sedimentary and volcanic detritus to pocket beaches locally. Lower Cretaceous mafic rocks contribute a few basaltic fragments and clinopyroxene, whereas more felsic younger products provide zircon grains with mid-Cretaceous ages (e.g., Equimina beach).

Provenance is dominantly from the Angola Block also in central Angola, as reflected by the same unimodal Eburnean zircon-age spectra and epidote-amphibole suites. Sand is however characterized by higher quartz/feldspar (Q/F; Fig. 2B) and lower plagioclase/feldspar (P/F) ratios, chiefly reflecting increasing weathering conditions (as discussed in section 8 below) rather than different provenance. Mafic igneous detritus documented by gabbroic rock fragments and clinopyroxene is most significant in Catumbela sands. In beaches from the Catumbela mouth to Luanda, clinopyroxene is invariably much more common than in local rivers (Fig. 3), indicating coastal dispersal of mafic igneous detritus derived from either the Catumbela mouth or Cretaceous syn-rift tholeiitic to post-rift alkaline basalts exposed at the landward termination of the Cuanza volcanic line ("anorogenic volcanic provenance" of Garzanti, 2016). Heavy-mineral concentration tends to 
581

582

583

584

585

be higher in beach sands than in river sands, but differences in heavy-mineral suites cannot be ascribed to hydrodynamic processes, because clinopyroxene is only slighly less dense than epidote and none of our samples show markedly anomalous SRD indices. Offshore samples are pyroxenepoor, which argues against longshore drift from the Catumbela mouth.

In northern Angola, the provenance signal is dimmed further by progressively stronger weathering effects. Mainly low-grade to lower medium-grade metasedimentary detritus from the West Congo Belt is documented by medium-rank schist and quartz-mica lithics, muscovite, biotite, and common garnet and kyanite; staurolite increases in relative abundance from northernmost Angola to the Congo. Quartz and durable heavy minerals recycled largely from Meso-Cenozoic coastal basins, but also partly from Neoproterozoic successions, are common in sands of rivers cutting across the Cuanza basin in their terminal tract, including the Longa, Bengo, and especially the Cuanza (as discussed in subection 7.3 below).

In the Congo, the provenance signal is largely obliterated by extreme weathering conditions, which coupled with extensive recycling produce pure quartzose sand with high ZTR (Figs. 2D, 4A,C; "craton interior provenance" of Dickinson, 1985; "recycled clastic provenance" of Garzanti, 2016).

\section{Physical processes controlling sand composition}

In this section we discuss the compositional modifications associated with physical processes in the depositional environment, namely hydraulic sorting, mechanical breakdown, and recycling.

\subsection{Hydraulic sorting}

Sorting of detrital grains based on their size, density, and shape occurs in all three stages of the sedimentary cycle, during erosion by selective entrainment, during transport by vertical partitioning of particles carried in suspension, and eventually during deposition according to their settling velocity (Komar 2007). Erosive processes may lead to extreme modifications of sand composition, as documented by common formation of garnet and magnetite beach placers in southern Angola 
608 (Garzanti et al., 2017). These lag deposits are generated during storm events when tectosilicate

609 grains - having smaller pivoting angles and projecting higher above the bed than smaller settling-

610

611

612

613

614

615

616

617 equivalent dense minerals and thus experiencing greater flow velocities and drag forces (Komar and Li 1988) - are selectively removed offshore. These phenomena are readily revealed by the anomalous concentration of dense and ultradense minerals, as reflected by bulk-sediment grain densities notably higher or lower than the estimated weighted average density of source rocks (ranging from $\sim 2.65 \mathrm{~g} / \mathrm{cm}^{3}$ for quartzarenites, quartzites and granites to $2.8-3.0 \mathrm{~g} / \mathrm{cm}^{3}$ for mafic igneous and metamorphic rocks; Garzanti et al., 2009). Among our samples, anomalously high grain densities are estimated for the Inamangando outer berm and for the Equimina and Cabo Ledo beaches (SRD between 2.77 and $2.94 \mathrm{~g} / \mathrm{cm}^{3}$ ), all notably enriched in opaque Fe-Ti-Cr oxides and zircon relative to adjacent beaches derived from similar source rocks. Placer lags rich in $\mathrm{Fe}-\mathrm{Ti}-\mathrm{Cr}$ oxides and zircon were sampled at the Catumbela mouth and sporadically observed in northern Angolan beaches (e.g., garnet-rich Ambriz sample). Such strong selective-entrainment effects are revealed readily by the anomalous concentration of elements hosted preferentially in ultradense minerals (e.g., Ti, REE, Zr, Hf, Nb, Ta, Cr), as well as by highly negative Eu anomalies (Garzanti et al., 2010). $\mathrm{Zr}$ and $\mathrm{Hf}$ concentrations reach 2474 and $49 \mathrm{ppm}$ in Equimina beach (Eu/Eu* 0.45), reflecting zircon abundance. The Eu anomaly is most strongly negative in the Inamangando outer berm $\left(\mathrm{Eu} / \mathrm{Eu}^{*} 0.28\right)$. Such hydrodynamic effects were not observed in river sands.

\subsection{Mechanical breakdown}

Mechanical wear is scarcely effective during even long-distance fluvial and longshore transport in acqueous media (Russell, 1937; Shukri, 1950; Breyer and Bart, 1978). Although feldspar is softer than quartz and has good cleavage, no significant decrease in the $\mathrm{Q} / \mathrm{F}$ ratio or in feldspar size is observed over a distance of eighteen hundred kilometers from the Orange mouth to southern Angola. We thus concluded that mechanical breakdown cannot modify the composition of passivemargin sand significantly (Garzanti et al., 2015). 
634 The Q/F ratio, however, decreases in offshore silts. In northern Namibia to southern Angola, 635 tectosilicate modes are very close in fine to medium Skeleton Coast and Moçamedes desert sands

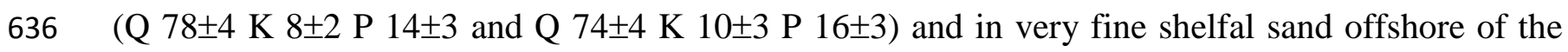

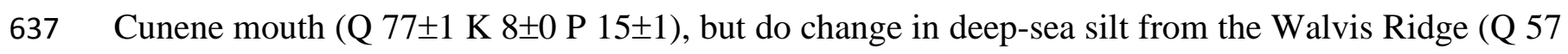
638 K 12 P 31). Cleavable feldspar thus concentrates in the silt fraction. In central Angola, feldspar 639 increases with grain size from Coporolo medium sand (Q 63 \pm 2 K 21 \pm 3 P 16 \pm 2 ) to deep-sea silty 640 clay (Q 39 K 25 P 36), but only slightly from fine to medium Balombo and Tapado river sands (Q $64155 \pm 2$ K $27 \pm 0$ P $18 \pm 3$ ) to very fine sand offshore (Q 49 \pm 6 K $29 \pm 0$ P $23 \pm 5$ ). Fine sand offshore of the 642 Congo mouth is richer in feldspar than beach sand, but chiefly because of longshore transport from 643 the south.

644 North of Namibe, where eolian dunefields are lacking, most silicates are observed to remain mainly 645 subangular in beach sand, indicating that mechanical wear during fluvial and longshore transport 646 has a limited influence on both composition and texture of sand-sized sediment.

\subsection{Recycling}

649 Recycling represents the most elusive problem by far in provenance analysis of modern sands 650 (Blatt, 1967). The presence of recycled detritus is qualitatively revealed by the occurrence of quartz 651 grains with abraded overgrowths or well-rounded outline and of shale, siltstone or sandstone rock 652 fragments, together with a series of parameters, including high $\mathrm{Q} / \mathrm{F}$ and ZTR indices and low P/F 653 and heavy-mineral concentration (Fig. 4C). All of these features characterize river and beach sands in northern Angola, and become extreme from northernmost Angola to the Congo (Fig. 7F,G). Any attempt to quantify precisely the amount of recycled versus first-cycle detritus is however unrobust, because mineralogical parameters indicative of recycling are generally affected by weathering as well (Garzanti, 2017). In southern Angola north of the Orange littoral cell, where 
660

661

662

663

664

665

666

667

668

669

670

671

672

673

674

675

676

677

678

679

680

681

682

683

684

685

in the Mariquita and Chapeu Armado pocket beaches, and very minor elsewhere. In central Angola, beach sands tend to be richer in quartz than river sands, suggesting that detritus recycled from coastal outcrops of sedimentary strata may reach up to $\sim 30 \%$, a percentage estimated tentatively to increase to $\sim 40 \%$ for Longa sand and to $\geq 50 \%$ for Cuanza sand. The recycled component, estimated to be $\sim 30 \%$ for Bengo sand and $\sim 15 \%$ for Dande sand, is prominent in beaches of northern Angola and overwhelming in the Congo, but an accurate estimate cannot be made because of strong superposed weathering effects. Recycled monocrystalline quartz is dominant in rivers draining Kalahari fossil dunes including middle Cunene tributaries as well as the uppermost Cuanza, the endorheic Okavango, the Cuando, and the upper Zambezi draining into the Indian Ocean. Detritus recycled from quartzose sandstones and metasandstones of the Neoproterozoic West Congo Belt occurs in all major rivers from the Cuanza to the Congo and it is most evident in Mebridege sand. Quartzose detritus recycled from siliciclastic strata of the Meso-Cenozoic Cuanza basin is most significant in Longa, Cuanza and Bengo sands, whereas Luculu sand and beach sand in northernmost Angola are recycled from Lower Congo basin strata (Fig. 1D).

Rivers of southern and central Angola carry very few garnet grains $(<3 \%$ of transparent heavy minerals), reflecting virtual lack of garnet in granitoid rocks of the Angola Block. Garnet represents $8 \%$ tHM in Chapeau Armado beach, indicating recycling of sandstones in the coastal Namibe basin. In northern Angola, garnet is significant (5-13\%tHM) in rivers between the Cuanza and the Onzo draining the northern part of the Cuanza basin, and it is common in Luculu sand draining the Lower Congo basin (33\%tHM) and in all beach sands between the Dande and Congo mouths (20 \pm 10 $\% \mathrm{tHM}$ ). The areal distribution of garnet along the Angolan rifted margin thus reveals that it is mostly recycled from siliciclastic strata of Meso-Cenozoic basins - ultimately derived from metasedimentary rocks of the West Congo Belt in northern Angola and of the Kaoko Belt in southern Angola - rather than first-cycle from basement rocks.

Interpretation of chemical data also suffers from the superposed effects of weathering and recycling. In river and beach sands from southern Angola to the Congo, Si increases markedly (corr. coeff. $\mathrm{r}=$ 
686

687

688

689

690

691

692

693

694

695

696

697

698

699

700

701

702

703

704

705

706

707

708

709

710

711

712

0.88, sign. lev. 0.1\%), whereas most other elements decrease, non-mobile Al most evidently $(\mathrm{r}=-$ 0.92). The sharp northward decrease in aluminum results from the superposed effects of selective feldspar breakdown by paleoweathering during previous sedimentary cycle(s), by intrastratal dissolution between successive cycle(s), and only last by hydrolisis in the present subequatorial climate. Because of such strong multiphase depletion in Al, chemical-weathering proxies including the CIA, PIA, CIX, and $\alpha^{\mathrm{Al}}$ may give unexpectedly low values in sand generated in hyper-humid equatorial climates (e.g., Congo sand; Table 1). The Eu anomaly is more strongly negative in sands containing more recycled quartz as suggested independently by detrital modes and textural features $\left(\mathrm{Eu} / \mathrm{Eu}^{*}\right.$ 0.45-0.50 for Cuanza and Longa sands, Eu/Eu* 0.50-0.70 for Mebridege and Congo river sands and all beaches north of $6^{\circ} 30^{\prime} S$ ). In order to single out the recycling effect we may calculate the ratio between the CIX (a truer indicator of weathering unaffected by the addition of biogenic, pedogenic, or extrabasinal carbonate grains) and the WIP (strongly influenced by quartz dilution; Garzanti et al., 2013). The CIX/WIP ratio does increase northward (Fig. 4), but the correlation ( $\mathrm{r}=$ $0.49)$ is barely significant.

\section{Weathering control and relative durability of detrital minerals}

The effect of weathering on Angolan continental-margin sediments, associated with both latitudinal climatic zonation and strong inland rainfall gradients, has been discussed in detail in a previous study focusing on clay minerals and sediment geochemistry (Dinis et al., 2017). Here we focus instead on sand composition, and discuss specifically the effects of subequatorial weathering on detrital modes and surface textures of quartz, feldspar, and heavy minerals (Fig. 7).

\subsection{Main framework grains}

In order to consider a homogeneous population of sediment samples, we have selected 23 river sands lacking clues of polycyclic origin (e.g., quartz grains with abraded overgrowths or well rounded outline, arenaceous rock fragments) and thus held to be derived dominantly first-cycle 
713 from crystalline basement. In this sample set, the quartz/feldspar ratio is $\geq 1$ in southern Angola, $\sim 2$ 714 in central Angola, and $~ 7$ in northern Angola (Figs. 2B and 4A). The plagioclase/K-feldspar ratio is $715>1$ in southern Angola and $\leq 1$ in central and northern Angola; cross-hatched microcline represents 716 $\sim 30 \%$ of K-feldspar grains in southern Angola and 45\% in central and northern Angola (Fig. 4B).

Because source rocks are broadly homogeneous in southern and central Angola, these trends are interpreted as chiefly weathering-controlled. Plagioclase disappears in the Congo, where microcline may be the only detrital feldspar present. Quartz is thus inferred to resist chemical dissolution far better than feldspars, K-feldspar somewhat better than plagioclase, and microcline somewhat better than orthoclase, confirming earlier observations (e.g., Blatt, 1967; James et al., 1981; McBride, 1985).

The same set of selected river sands were photographed, and the degree of weathering evaluated on both thin sections and microphotographs by two different operators, based on the presence and depth of etch pits, and on the degree of replacement of quartz and feldspar lattice by clay plasma (Fig. 7). We subdivided the samples in groups with similar frequency and extent of alteration features, and then ranked them - from the apparently least weathered to the apparently most weathered - in five independent trials. A trend of increasing weathering with decreasing southern latitude was obtained in all trials, with a median of Spearman rank correlation coefficients of $0.76 \pm$ 0.25 (sign. lev. 0.1\%); the rather large standard deviation reflects the considerable degree of subjectivity involved in qualitative judgments.

The compositional change associated with the strong W/E climatic gradient was investigated in the Catumbela catchment, where we studied sands carried by three tributaries draining progressively more humid areas farther from the coast. The $\mathrm{Q} / \mathrm{F}$ ratio is observed to increase rapidly and the $\mathrm{P} / \mathrm{F}$ ratio to decrease in sands derived from more humid areas of the interior. Highest $\mathrm{Q} / \mathrm{F}$ and lowest P/F ratios characterize trunk-river sand derived largely from humid headwater highlands (Fig. 2C). These samples, although limited in number, display a much sharper weathering-controlled compositional trend than the one associated with latitudinal climatic zonation. 


\subsection{Heavy minerals}

741 Pyroxene and amphibole grains are mostly corroded, and show a higher degree of weathering 742 relative to all other heavy minerals in most samples. Epidote and staurolite are commonly corroded and occasionally deeply etched or skeletal. Andalusite, garnet, kyanite, titanite, and apatite are also corroded, but etched or deeply etched only locally. Tourmaline is corroded more commonly than rutile, and rutile more commonly than zircon. Etch pits do not appear to increase remarkably in frequency or depth with decreasing latitude. A latitudinal trend is best displayed by clinopyroxene, and specifically by deeply etched to skeletal clinopyroxene grains, which are most common north of Luanda where etched garnet is also recorded. Garnet, widely considered as relatively resistant conditions than in northern Angola.

\subsection{Chemical proxies}

Among chemical indices of weathering, only the WIP correlates very well with latitude $(\mathrm{r}=0.91)$.

This is simply because it reflects the combined effects of weathering and recycling, which both increase notably in northern Angola and very markedly in the Congo (Fig. 4). Among indices unaffected by quartz dilution but sensitive to source-rock lithology, only the CIX correlates with latitude relatively well $(\mathrm{r}=0.62$, sign. lev. $0.1 \%) ; \alpha^{\mathrm{Al}} \mathrm{Na}, \alpha^{\mathrm{Al}} \mathrm{K}$ and $\alpha^{\mathrm{Al}} \mathrm{Rb}$ correlate poorly $(\mathrm{r}=0.42$ 0.49; sign. lev. 1\%). Indices considering $\mathrm{Ca}\left(\mathrm{CIA}, \mathrm{PIA}, \alpha{ }^{\mathrm{Al}} \mathrm{Ca}\right)$ are uncorrelated with latitude, being low to even very low in Bengo, Cuanza, and Longa river sands of northern Angola containing carbonate rock fragments derived from Meso-Cenozoic basins (Fig. 8). Relative to aluminum and with reference to the UCC standard, depletion in $\mathrm{Na}, \mathrm{Ca}$, and $\mathrm{K}$ is not particularly strong in northern Angolan sands, suggesting that plagioclase is not much less durable than K-feldspar and that 
recycling is more responsible than weathering for feldspar depletion (Nesbitt et al., 1997) (Fig. 4). A markedly negative Eu anomaly produced by plagioclase breakdown (McLennan, 1993; Condie et al., 1995) is not observed in river sands of northermost Angola (e.g., Eu/Eu* 0.89 in Loge sand), where plagioclase is as abundant as K-feldspar. Final plagioclase breakdown is indicated by the sharp increase of the CIA, CIX, and especially of $\alpha^{\mathrm{Al}} \mathrm{Na}$ in the Congo (Table 1).

\section{Passive-margin sand and the arkose-quartzarenite problem}

The traditional view in sedimentary petrology is that passive-margin sands are generated from the adjacent cratonic block - held to consist of gneissic-granitoid basement with cover strata - and thus contain quartz and feldspar with few lithic fragments ("continental block provenance" of Dickinson, 1985). Such sand suites are basically distinguished by their Q/F ratio, which may be $\leq 1$ ("ideal arkose" of Dickinson, 1985) either where tectonic activity is particularly intense ("tectonic arkose" of Folk, 1980; "basement uplift subprovenance" of Dickinson, 1985) and/or in arid climatic conditions ("climatic arkose" of Folk, 1980). Instead, in case of tectonic quiescence favoring prolonged weathering in low-relief shield areas, quartz would dominate over mainly K-feldspar ("craton interior subprovenance" of Dickinson, 1985).

As a first approximation, this case study on sediment generation along the magma-poor Angolan passive margin represents a neat confirmation of such a simplified conceptual framework. Firstcycle quartzo-feldspathic to feldspar-rich feldspatho-quartzose sand eroded from mid-crustal granitoid gneisses of the Angola Block exposed in the dynamically uplifted Bié-Huila dome is deposited in arid southern Angola, whereas quartz-rich feldspatho-quartzose to quartzose sand characterizes the lower-relief and more intensely weathered rifted margin of humid northern Angola, where sedimentary and metasedimentary rocks are more common. Pure quartzose, largely recycled sand is generated in the vast, low-lying hyperhumid Congo basin (Giresse, 2005). Sand composition in these three segments of the African passive margin thus reflects northward 
decreasing dissection of the Congo craton (i.e., dissected, transitional, and undissected stages of continental block provenance; Garzanti, 2016).

Such an apparently simple scenario stems from three distinct processes acting in accord. Stronger tectonic uplift in the arid south, and stronger weathering coupled with extensive recycling in the humid north determine a progressive northward increase of more durable quartz and heavy minerals such as zircon, tourmaline and rutile, relative to less durable minerals such as plagioclase, amphibole and pyroxene. The superposition of such partly interrelated effects makes it difficult to quantify the relative importance of each, which has always represented a major drawback in the paleotectonic and paleoclimatic interpretation of ancient passive-margin sandstones (e.g., Johnsson, 1993). Particularly hard to infer from detrital modes is the importance of recycling, because chemical dissolution during diagenesis of parent sandstones may produce similar effects as weathering of daughter sands (Velbel and Saad, 1991). One key, although chiefly qualitative, is provided by the shape of quartz grains, rounded in the case of recycling especially of eolian parent sandstones, deeply etched in the case of subequatorial weathering (Fig. 7).

Angolan sands present a relatively simple case also because this tract of the Atlantic rifted margin is essentially non-volcanic, with limited syn-rift to post-rift magmatic activity confined to a few coastal areas. Basaltic detritus derived from as far as Lesotho highlands represents $4 \pm 2 \%$ of dune and beach sands of the Moçamedes Desert, where it provides the most distinctive trace of ultralongdistance littoral transport from the Orange river mouth. North of the Moçamedes Desert, basaltic rocks fragments, clinopyroxene and detrital zircons with mid-Cretaceous U-Pb ages occur in a few river sands (e.g., Cambongo, Quicombo) and in several beaches from southern to central Angola, where volcanic detritus represents $\leq 2 \%$ of bulk sand. Anorogenic volcanic provenance is thus minor, which is not the case for many other regions of southern Africa still widely preserving remnants of the widespread Jurassic Karoo and Cretaceous Etendeka flood basalts (Garzanti et al., 2014a). 
820 The N/S trending Angolan continental margin, located in the subequatorial belt of the Southern 821 Hemisphere where climate changes progressively with latitude from hyperarid in tropical Namibia 822 to hyperhumid in equatorial Congo, offers an exceptionally suitable natural laboratory in which to 823 study the effects of climatic-induced weathering on sediment composition. Excepting the 824 Moçamedes Desert in the south, where sand is mainly supplied by ultralong littoral transport from 825 the Orange river mouth, Angolan sand suites consist chiefly of quartz and feldspar derived first826 cycle from granitoid Precambrian basement but also partly recycled from Meso-Cenozoic basins 827 formed during initial rifting of the South Atlantic. Sand samples were thus formally classified by 828 their quartz/feldspar ratio as quartzo-feldspathic $(\mathrm{Q} / \mathrm{F}<1)$, feldspar-rich $(1<\mathrm{Q} / \mathrm{F}<2)$ to quartz-rich $829(4<\mathrm{Q} / \mathrm{F}<9)$ feldspatho-quartzose, and quartzose $(\mathrm{Q} / \mathrm{F}>9$; pure quartzose if $\mathrm{Q} \% \mathrm{QFL}>$ 95; Fig. $8302 \mathrm{~A})$.

831 Quartzo-feldspathic to feldspar-rich feldspatho-quartzose sands characterize the arid south adjacent 832 to dynamically uplifted highlands. Moving toward the humid equator, river and beach sands pass 833 from feldspatho-quartzose in central Angola to mostly quartz-rich feldspatho-quartzose in northern 834 Angola, quartzose in northernmost Angola, and eventually pure quartzose in the Congo. Sharper 835 compositional trends are associated with the steep E/W climatic gradient, reflecting much stronger 836 chemical weathering in humid highlands than along the arid coast. Minor volcanic detritus is 837 supplied locally by Cretaceous lavas exposed close to the coast. Heavy-mineral suites are generally 838 dominated by epidote and amphibole. North of the Moçamedes Desert, clinopyroxene is present in a 839 few pocket beaches of southern Angola and widespread in beaches of central Angola. Garnet 840 associated with kyanite is common in beaches of northern Angola, where it is largely recycled from 841 sandstone strata of the Cuanza and Lower Congo basins and ultimately derived from 842 metasedimentary rocks of the West Congo Belt (Fig. 3). The dual time structure of Angolan source 843 rocks is best reflected by $\mathrm{U}-\mathrm{Pb}$ ages of detrital zircons, characterized by unimodal spectra with 844 sharp Eburnean peak at $~ 2$ Ga from north of Namibe to south of the Cuanza mouth, and by broader 845 multimodal distributions in northern Angola, with a few Permo-Triassic ages locally and additional 
846 clusters at 0.5-0.7 Ga, 1 Ga, and 2.5-2.7 Ga best defined in Congo estuary sand (Fig. 5). Among 847 chemical indices of weathering, the WIP correlates well with latitude because it reflects the 848 superposed effects of weathering and recycling. Other indices correlate poorly because they are 849 largely affected by source-rock lithology as well (Fig. 4). Depletion in $\mathrm{Ca}$, Na, and K is not very 850 strong even in northern Angola, where plagioclase results to be not much less durable than K851 feldspar and recycling is more responsible than weathering for feldspar depletion. Feldspar and 852 garnet are weathered out only in the hyperhumid climate of the Congo.

853 This modern study of Angolan sands shows how extracting the climatic signal from sediment 854 composition is not straightforward, because multiple controlling factors operate in nature 855 simultaneously, and because mineralogical and geochemical proxies do not respond to weathering 856 only but are affected by other variables, including source-rock lithology, hydraulic sorting, and 857 recycling as well.

\section{ACKNOWLEDGMENTS}

860 Fundamental logistic support by the University of Katyavala Bwila and the Instituto Superior Politécnico da Tundavala, and kind help by Manuel Bandeira, Silvano Levy, Margarida Ventura, and Carlos Ribeiro are very warmly appreciated. Additional samples from Angola and the Congo were kindly provided by Edson Baptista, Francesca Bolognesi, Daniela Dell'Era, Raffaele Giardini, 864 Maurizio Orlando, Alcides Pereira, Afonso Sampaio, and Armanda Trindade. Ethan Petrou helped 865 with geochronological analyses and Elisa Malinverno with determination of fossil assemblages. Constructive reviews by two anonymous reviewers and Editor Sebastien Bertrand were gratefully 867 received.

\section{SUPPLEMENTARY MATERIAL}

870 Supplementary data associated with this article, to be found in the online version at , include information on sampling sites (Table A1) and river catchments 
872 (Table A2), together with the complete datasets on bulk-sand petrography (Table A3), heavy 873 minerals (Table A4), surface textures (Table A5), sand geochemistry (Table A6) and detrital-zircon 874 geochronology (Appendix B). Figure A1 illustrating river profiles, and the Google-Earth ${ }^{\mathrm{TM}}$ map of 875 sampling sites Angolamargin.kmz are also provided.

876 


\section{FIGURE CAPTIONS}

Figure 1. Topography, climate, and geology of Angola. A) Google Earth ${ }^{\mathrm{TM}}$ image showing the recently uplifted Bié-Huila plateau of southwestern Angola, lying largely at altitudes above $1500 \mathrm{~m}$ and delimited by very steep scarps cleaved by deep narrow gorges in the northwest (Lopes et al., 2016). Location of river (green), dune (orange), beach (yellow), and offshore samples (white; MARUM sites GeoB 1000->1008, 1011->1014, 1019->1022, 1702, 1704->1706, and 4918; DSDP Leg 40 site 365 and ODP Leg 175 sites 1078->1080 in italics) is indicated. B) Location and river map. C) Rainfall map (annual precipitation in mm; Hijmans et al., 2005). D) Geological sketch map (redrawn after Schlüter, 2008 and various sources cited in the text).

Figure 2. Petrographic classification and effects of weathering and recycling in subequatorial passive-margin sands. Data points: intensity of blue color increases with increasing rainfall at decreasing southern latitude; outline ranges from black to light grey with increasing estimated proportion of recycled component. A) The proposed refined classification of lithic-poor sands and sandstones. B) River sands chiefly derived first-cycle from basement rocks display a latitudinal trend of quartz enrichment controlled by climatic zonation. Latitude and average rainfall are indicated for Mebridege River in the north and Bero River in the south. C) The W/E inland trend of weathering-controlled quartz enrichment is well displayed in the Catumbela catchment. The $\mathrm{Q} / \mathrm{F}$ ratio increases systematically in sand of tributaries draining progressively farther from the coast, being highest in trunk-river sand derived largely from humid interior highlands. The opposite trend is displayed by the $\mathrm{P} / \mathrm{F}$ ratio, indicating selective dissolution of plagioclase. Longitude of headwaters and average rainfall are indicated for each catchment. D) River sands containing a significant recycled component as revealed by textural and mineralogical parameters are enriched further in quartz, reaching pure quartzose compositions in hyperhumid Congo. E) Cunene sands are a mixture of pure quartzose sand recycled from the fossil Kalahari Desert in the middle reaches and unweathered first-cycle quartzo-feldspathic sand eroded from crystalline basement in the dry lower 
reaches (Fig 1C). Sand composition in the terminal tract of the Curoca River reflects extensive mixing with eolian coastal sand derived mainly from the Orange mouth.

Figure 3. Heavy-mineral suites of Angolan passive-margin sands. Moçamedes desert sands are richer than Skeleton Coast sands in amphibole and epidote contributed by the Cunene River; offshore sands are hydrodynamically depleted in garnet. Angolan basement chiefly supplies epidote and amphibole. From the Catumbela mouth to Luanda, beach sand is richer in clinopyroxene than river sand. From northern Angola to the Congo, beach sand is enriched in garnet, next in kyanite, and finally in staurolite, all largely recycled from Meso-Cenozoic strata of the northern Cuanza and Lower Congo basin and ultimately derived from metasedimentary rocks of the West Congo Belt. Both multivariate observations (points) and variables (rays) are displayed in the compositional biplot (Gabriel, 1971). The length of each ray is proportional to the variance of the corresponding element in the data set. If the angle between two rays is close to $0^{\circ}, 90^{\circ}$, or $180^{\circ}$, then the corresponding elements are directly correlated, uncorrelated, or inversely correlated, respectively.

Figure 4. Latitudinal variation of key compositional parameters in river sands. Three-pointcentered moving averages of all indices reflect extensive recycling of fossil Kalahari dunes in the middle Cunene catchment (right end of panels) and the combined effects of weathering and recycling in the Congo (left end of panels). A) The quartz/feldspar (Q/F) ratio shows the same trend as the CIX/WIP ratio, indicating the overwhelming effect of recycling. B) Metamorphic rank of rock fragments (MI) reflects mainly first-cycle provenance of Angolan sands from low to mediumgrade basements; mixing with detritus from siliciclastic covers is major in rivers draining the Kalahari (right end), the Cuanza basin (center left), and the Congo basin (left end). Plagioclase (P) tends to decrease slighly with decreasing latitude relative to $\mathrm{K}$-feldspar $(\mathrm{KF} ; \mathrm{r}=0.60)$, and microcline (Mic) to increase imperceptibly relative to orthoclase $(r=0.37)$. C) The anticorrelation between the relative concentration of durable minerals (ZTR) and the absolute concentration of transparent heavy minerals (tHMC) is chiefly a recycling effect. D) Among the variants of the CIA 
931 932 933 934 935 936

unaffected by quartz dilution, the CIX proves to be the most accurate indicator of weathering. The WIP, markedly affected by quartz dilution, decreases sharply in northern Angola. E) Among alfa indices: $\alpha^{\mathrm{Al}} \mathrm{Na}$ is the best indicator of weathering, although affected by recycling as well; $\alpha^{\mathrm{Al}} \mathrm{Ca}$ is affected by local occurrence of carbonate grains (e.g., Bengo sand); $\alpha^{\mathrm{Al}} \mathrm{Mg}$ and $\alpha^{\mathrm{Al}} \mathrm{K}$ show opposite behaviour, increasing in sands derived from felsic and mafic sources, respectively.

Figure 5. U-Pb age spectra of detrital zircons (age vs. frequencies plotted as Kernel Density Estimates using the provenance package of Vermeesch et al., 2016). Moçamedes desert sand in the south displays the same Damara and Namaqua peaks as Skeleton Coast sand mostly derived from the Orange River. Unimodal distributions with sharp Eburnean peak characterize sands of central Angola. Zircons from Cretaceous magmatic rocks are most common in Equimina beach. Spectra become broader and finally markedly multimodal in northern Angola, with prominent Pan-African, Namaqua, Eburnean, and Neoarchean clusters best displayed in Congo estuary sands.

Figure 6. Petrography of offshore sediments sampled during DSDP, ODP and Meteor expeditions. Shelfal sands to deep-sea sandy silts are variously enriched in planktonic foraminifers (Walvis Ridge), green glaucony (offshore Cunene mouth), benthic foraminifers (offshore Tapado mouth), and brown goethite ooids or pellets (offshore Congo mouth). Skeleton Coast dunes include basaltic rock fragments and clinopyroxene derived from the Orange River; the Congo River carries pure quartzose sand. Water depths are indicated; white circle for scale $=250 \mu \mathrm{m}$.

Figure 7. The effects of weathering and recycling on surface textures of sand grains. A,B) Numerous etch pits and re-entrants commonly filled with clay "plasma" testify to intense weathering even of quartz and other durable grains in river sands of northern Angola. Note strong leaching and deep penetration of iron-stained clay in: C) monocrystalline quartz; D) polycrystalline quartz; E) microcline. F,G) Abundance of rounded quartz grains testifies to extensive recycling of 
958

959

960

961

962

963

964

965

966

967

968

969

970

971

972

973

974

975

976

977

978

979

980

981

982

983

Meso-Cenozoic siliciclastic units in the Cuanza and Congo catchments. All photos with crossed polars; blue bar for scale $=250 \mu \mathrm{m}$.

Figure 8. Inability of chemical indices to effectively single out weathering control from the effects of provenance, recycling, and hydraulic sorting in Angolan river sands. Both multivariate observations (points) and variables (rays) are displayed in the compositional biplot (Gabriel, 1971). Mobile alkali and alkaline earth elements largely reflect their original concentration in source-rock lithologies, and thus the CIA and its variants correlate poorly with latitude; $\alpha^{\mathrm{Al}} \mathrm{Mg}, \alpha^{\mathrm{Al}} \mathrm{Ca}$ and $\alpha^{\mathrm{Al}} \mathrm{Sr}$ (higher for felsic sources) anticorrelate with $\alpha^{\mathrm{Al}} \mathrm{K}, \alpha^{\mathrm{Al}} \mathrm{Rb}$ and $\alpha^{\mathrm{Al}} \mathrm{Ba}$ (higher for mafic sources). Being affected by quartz dilution, the WIP decreases markedly toward the equator reflecting the combined effect of recycling and weathering. The more reliable indicator of weathering is $\alpha^{\mathrm{Al}} \mathrm{Na}$. The Eu anomaly tends to become more negative with weathering, but also with recycling and in sands derived from more felsic source rocks or in placer lags. The hydraulic-sorting effect is displayed by placer and semiplacer deposits formed at the Catumbela and Inamangando mouths (symbols with purple outline). Some beaches and a few river sands (e.g., Bengo, Longa; symbols with yellow outline) contain intrabasinal or extrabasinal carbonate grains and thus plot lower in the diagram because of their very low $\alpha{ }^{\mathrm{Al}} \mathrm{Ca}$ (and low $\alpha{ }^{\mathrm{Al}} \mathrm{Sr}$ ).

Table 1. Key petrographic, heavy-mineral, and geochemical parameters of Angolan passive-margin sands. $\mathrm{N}^{\circ}=$ number of samples; $\mathrm{Qz}=$ quartz; $\mathrm{KF}=\mathrm{K}$-feldspar; $\mathrm{Pl}=$ plagioclase $; \mathrm{L}=$ aphanitic lithic grains $($ Lvm $=$ volcanic and metavolcanic $;$ Lsm $=$ sedimentary and metasedimentary $;$ Lm $=$ highrank metamorphic); $\mathrm{MI}^{*}=$ metamorphic index; $\mathrm{HM}=$ heavy minerals; tHMC = transparent heavymineral concentration; ZTR = zircon + tourmaline + rutile; Ep = epidote $;$ Grt = garnet; St = staurolite; Ky = kyanite; Amp = amphibole; Px = pyroxene; \&tHM = other transparent heavy minerals (apatite, titanite, and rare sillimanite, andalusite, olivine, barite, monazite, allanite, or scheelite). Chemical weathering indices cannot be calculated reliably for offshore sediments 
984 containing abundant intrabasinal grains and authigenic minerals, including calcareous and non985 calcareous allochems, glaucony, phosphates, sulphates, or iron ooids.

986 


\section{REFERENCES}

Al-Hajri, Y., White, N., Fishwick, S., 2009. Scales of transient convective support beneath Africa. Geology, 37, 883-887.

Alberti, A., Piccirillo, E.M., Bellieni, G., Civetta, L., Comin-Chiaramonti, P., Morais, E.A.A., 1992. Mesozoic acid volcanics from southern Angola: petrology, $\mathrm{Sr}-\mathrm{Nd}$ isotope characteristics and correlation with acid stratoid volcanic suites of the Paranà basin (southeastern Brazil). European Journal of Mineralogy, 4, 597-604.

Andò, S., Vignola, P., Garzanti, E., 2011. Raman counting: a new method to determine provenance of silt Rendiconti Lincei Scienze Fisiche e Naturali, 22, 327-347.

Andò, S., Garzanti, E., Padoan, M., Limonta, M., 2012. Corrosion of heavy minerals during weathering and diagenesis: a catalog for optical analysis. In: von Eynatten, H., Critelli, S., Ingersoll, R.V., Weltje, G.J. (Eds.), Actualistic Models of Sediment Generation. Sedimentary Geology, 280, 165-178.

Andò, S., Morton, A., Garzanti, E. 2014. Metamorphic grade of source rocks revealed by chemical fingerprints of detrital amphibole and garnet. In: Scott, R.A., Smyth. H.R., Morton, A.C., Richardson, N. (Eds.), Sediment provenance studies in hydrocarbon exploration and production. Geological Society London, Special Publication 386, 351-371.

Anka, Z., Seranne, M., Di Primio, R., 2010. Evidence of a large upper-Cretaceous depocentre across the continent-ocean boundary of the Congo-Angola basin. Implications for palaeo-drainage and potential ultra-deep source rocks. Marine and Petroleum Geology, 27, 601-611.

Basu, A., 1985. Influence of climate and relief on compositions of sands released at source areas. In: Zuffa, G.G. (Ed.), Provenance of arenites. Reidel, Dordrecht, NATO ASI Series, 148, pp. 1-18.

Bate, R.H., Cameron, N., Brandão, M.G.P., 2001. Lower Cretaceous (pre-salt) lithostratigraphy of the Kwanza Basin, Angola. Newsletters on Stratigraphy, 38, 117-127.

Becker, T., Schreiber, U., Kampunzu, A.B., Armstrong, R., 2006. Mesoproterozoic rocks of Namibia and their plate tectonic setting. Journal of African Earth Sciences, 46, 112-140.

Blatt, H. 1967. Provenance determinations and recycling of sediments. Journal of Sedimentary Petrology, 37, 1031-1044.

Breyer, J.A., Bart, H.A., 1978. The composition of fluvial sands in a temperate semiarid region. Journal of Sedimentary Petrology, 48, 1311-1320.

Castillo-Oliver, M., Galí, S., Melgarejo, J.C., Griffin, W.L., Belousova, E., Pearson, N.J., Watangua, M., O'Reilly, S.Y., 2016. Trace-element geochemistry and U-Pb dating of perovskite in kimberlites of the Lunda Norte province (NE Angola): petrogenetic and tectonic implications. Chemical Geology, 426, 118-134.

Chaboureau, A.C., Guillocheau, F., Robin, C., Rohais, S., Moulin, M., Aslanian, D., 2013. Paleogeographic evolution of the central segment of the South Atlantic during Early Cretaceous times: paleotopographic and geodynamic implications. Tectonophysics, 604, 191-223.

Comin-Chiaramonti, P., De Min, A., Girardi, V.A.V., Ruberti, E., 2011. Post-Paleozoic magmatism in Angola and Namibia: a review. In: Beccaluva, L., Bianchini, G., Wilson, M. (Eds.), Volcanism and Evolution of the African Lithosphere. Geological Society of America, Special Paper 478, pp. 223-247.

Condie, K.C., Dengate, J., Cullers, R.L., 1995. Behavior of rare earth elements in a paleoweathering profile on granodiorite in the Front Range, Colorado, USA. Geochimica ec Cosmochimica Acta, 59, 279-294.

De Carvalho, H., Tassinari, C., Alves, P.H., Guimarães, F., Simões, M.C., 2000. Geochronological review of the Precambrian in western Angola: links with Brazil. Journal of African Earth Sciences, 31, 383-402. 
1030

1031

1032

1033

1034

1035

1036

1037

1038

1039

1040

1041

1042

1043

1044

1045

1046

1047

1048

1049

1050

1051

1052

1053

1054

1055

1056

1057

1058

1059

1060

1061

1062

1063

1064

1065

1066

1067

1068

1069

1070

1071

1072

Delhal, J., Ledent, D., Torquato, J.R., 1976. Nouvelles données géochronologiques relatives au complexe gabbro-noritique et charnockitique du bouclier du Kasai et à son prolongement en Angola. Ann. Société Géologique Belgique, 99, 211-226.

De Waele, B., Johnson, S.P., Pisarevsky, S.A., 2008. Palaeoproterozoic to Neoproterozoic growth and evolution of the eastern Congo Craton: its role in the Rodinia puzzle. Precambrian Research, 160, 127141.

Dickinson, W.R. 1985. Interpreting provenance relations from detrital modes of sandstones. In: Zuffa, G.G. (Ed.), Provenance of arenites. Dordrecht, Reidel, NATO ASI Series, 148, pp. 333-361.

Dinis, P., Huvi, J., Cascalho, J., Garzanti, E., Vermeesch, P., Callapez, P., 2016. Sand-spits systems from Benguela region (SW Angola). An analysis of sediment sources and dispersal from textural and compositional data. Journal of African Earth Sciences, 117, 171-182.

Dinis, P., Garzanti, E., Vermeesch, P., Huvi, J., 2017. Climatic zonation and weathering control on sediment composition (Angola). Chemical Geology, 467, 110-121.

Diniz, A.C., 2006. Características mesológicas de Angola : descrição e correlação dos aspectos fisiográficos, dos solos e da vegetação das zonas agrícolas angolanas. Lisboa, Instituto Português de Apoio ao Desenvolvimento, $546 \mathrm{p}$.

Drüppel, K., Littmann, S., Romer, R.L., Okrusch, M., 2007. Petrology and isotope geochemistry of the Mesoproterozoic anorthosite and related rocks of the Kunene Intrusive Complex, NW Namibia. Precambrian Research, 156, 1-31.

Dupré, B., Gaillardet, J., Rousseau, D., Allègre, C.J., 1996. Major and trace elements of river-borne material: the Congo Basin. Geochimica et Cosmochimica Acta, 60, 1301-1321.

Ernst, R.E., Pereira, E., Hamilton, M.A., Pisarevsky, S.A., Rodriques, J., Tassinari, C.C.G., Teixeira, W., Van-Dunem, V., 2013. Mesoproterozoic intraplate magmatic 'barcode' record of the Angola portion of the Congo Craton: newly dated magmatic events at 1505 and $1110 \mathrm{Ma}$ and implications for Nuna (Columbia) supercontinent reconstructions. Precambrian Research, 230, 103-118.

Ewart, A., Marsh, J.S., Milner, S.C., Duncan, A.R., Kamber, B.S., Armstrong, R.A., 2004. Petrology and geochemistry of Early Cretaceous bimodal continental flood volcanism of the NW Etendeka, Namibia. Journal of Petrology, 45, 59-138.

Feio, M., 1981. O relevo do sudoeste de Angola; estudo de geomorfologia. Memórias da Junta de Investigações Científicas do Ultramar, 67, 1-67.

Folk, R.L., 1980. Petrology of sedimentary rocks. Hemphill, Austin. 185 p.

Fort, X., Brun, J.P., Chauvel, F., 2004. Salt tectonics on the Angolan margin, synsedimentary deformation processes. American Association of Petroleum Geologists Bulletin, 88, 1523-1544.

Franke, D., 2013. Rifting, lithosphere breakup and volcanism: comparison of magma-poor and volcanic rifted margins. Marine and Petroleum Geology, 43, 63-87.

Franzinelli, E., Potter, P.E. 1983. Petrology, chemistry, and texture of modern river sands, Amazon River system. The Journal of Geology, 91, 23-39.

Frimmel, H.E., Tack, L., Basei, M.S., Nutman, A.P., Boven, A., 2006. Provenance and chemostratigraphy of the Neoproterozoic West Congolian Group in the Democratic Republic of Congo. Journal of African Earth Sciences, 46, 221-239.

Frimmel, H.E., Basei, M.S., Gaucher, C., 2011. Neoproterozoic geodynamic evolution of SW-Gondwana: a southern African perspective. Interanational Journal of Earth Sciences, 100, 323-354.

Gabriel, K.R., 1971. The biplot graphic display of matrices with application to principal component analysis. 
Gaillardet, J., Dupré, B., Allègre, C.J., 1999. Geochemistry of large river suspended sediments: silicate weathering or recycling tracer? Geochimica et Cosmochimica Acta, 63, 4037-4051.

Galehouse, J.S., 1971. Point counting. In: Carver, R.E. (Ed.), Procedures in sedimentary petrology. Wiley, New York, pp. 385-407.

Garzanti, E., 2016. From static to dynamic provenance analysis - Sedimentary petrology upgraded. In: Caracciolo, L., Garzanti, E., von Eynatten, H., Weltje, G.J. (Eds.), Sediment generation and provenance: processes and pathways. Sedimentary Geology, 336, 3-13.

Garzanti E., 2017. The maturity myth in sedimentology and provenance analysis. Journal of Sedimentary Research, 87, 353-365.

Garzanti, E., Andò, S., 2007. Heavy-mineral concentration in modern sands: implications for provenance interpretation. In: Mange, M.A., Wright, D.T. (Eds.), Heavy minerals in use. Elsevier, Amsterdam, Developments in Sedimentology Series, 58, 517-545.

Garzanti, E., Resentini, A., 2016. Provenance control on chemical indices of weathering (Taiwan river sands). In: Caracciolo, L., Garzanti, E., von Eynatten, H., Weltje, G.J. (Eds.), Sediment generation and provenance: processes and pathways.Sedimentary Geology, 336, 81-95.

Garzanti, E., Vezzoli, G. 2003. A classification of metamorphic grains in sands based on their composition and grade. Journal of Sedimentary Research, 73, 830-837.

Garzanti, E., Andò, S., Vezzoli, G., 2009. Grain-size dependence of sediment composition and environmental bias in provenance studies. Earth and Planetary Science Letters, 277, 422-432.

Garzanti, E., Andó, S., France-Lanord, C., Vezzoli, G., Najman, Y., 2010. Mineralogical and chemical variability of fluvial sediments. 1. Bedload sand (Ganga-Brahmaputra, Bangladesh). Earth and Planetary Science Letters, 299, 368-381.

Garzanti, E., Andò, S., Vezzoli, G., Lustrino, M., Boni, M., Vermeesch, P., 2012a. Petrology of the Namib sand sea: long-distance transport and compositional variability in the wind-displaced Orange Delta. Earth-Science Reviews, 11, 173-189.

Garzanti, E., Resentini, A., Vezzoli, G., Andò, S., Malusà, M., Padoan, M., 2012b. Forward compositional modelling of Alpine orogenic sediments. In: von Eynatten, H., Critelli, S., Ingersoll, R.V., Weltje, G.J., Actualistic Models of Sediment Generation. Sedimentary Geology, 280, 149-164.

Garzanti, E., Padoan, M., Andò, S., Resentini, A., Vezzoli, G., Lustrino, M., 2013. Weathering and relative durability of detrital minerals in equatorial climate: sand petrology and geochemistry in the East African Rift. The Journal of Geology, 121, 547-580.

Garzanti, E., Vermeesch, P., Padoan, M., Resentini, A., Vezzoli, G., Andò, S., 2014a. Provenance of passivemargin sand (southern Africa). The Journal of Geology, 122, 17-42.

Garzanti, E., Padoan, M., Setti, M., López-Galindo, A., Villa, I.M., 2014b. Provenance versus weathering control on the composition of tropical river mud (southern Africa). Chemical Geology, 366, 61-74.

Garzanti, E., Vermeesch, P., Andò, S., Lustrino, M., Padoan, M. and Vezzoli, G., 2014c. Ultra-long distance littoral transport of Orange sand and provenance of the Skeleton Coast Erg (Namibia). Marine Geology, $357,25-36$.

Garzanti, E., Resentini, A., Andò, S., Vezzoli, G., Vermeesch, P., 2015. Physical controls on sand composition and relative durability of detrital minerals during long-distance littoral and eolian transport (coastal Namibia). Sedimentology, 62, 971-996.

Garzanti, E., Dinis, P., Vermeesch, P., Andò, S., Hahn, A., Huvi, J., Limonta, M., Padoan, M., Resentini, A., 
Rittner, M., Vezzoli, G., 2017. Sedimentary processes controlling ultralong cells of littoral transport : placer formation and termination of the Orange sand highway in southern Angola. Sedimentology, doi: $10.1111 /$ sed.12387.

Gindre-Chanu, L., Warren, J.K., Puigdefabregas, C., Sharp, I.R., Peacock, D.C.P., Swart R., Poulsen, R., Ferreira, H., Henrique, L., 2015. Diagenetic evolution of Aptian evaporites in the Namibe Basin (southwest Angola). Sedimentology, 62, 204-233

Gindre-Chanu, L., Perri E., Sharp, I.R., Peacock, D.C.P., Swart, R., Poulsen R., Ferreira, H., Machado, V., 2016. Origin and diagenetic evolution of gypsum and microbialitic carbonates in the Late Sag of the Namibe Basin (SW Angola). Sedimentary Geology, 342, 133-153.

Giresse, P., Hoang, C.T., Kouyoumontzakis, G., 1984. Analysis of vertical movements deduced from a geochronological study of marine Pleistocene deposits, southern coast of Angola. Journal of African Earth Sciences, 2, 177-187.

Giresse, P., 2005. Mesozoic-Cenozoic history of the Congo Basin. Journal of African Earth Sciences, 43, 301-315.

Goscombe, B., Gray, D.R., 2007. The Coastal Terrane of the Kaoko Belt, Namibia: outboard arc-terrane and tectonic significance. Precambrian Research, 155, 139-158.

Goscombe, B., Hand, M., Gray, D., Mawby, J., 2003. The metamorphic architecture of a transpressional orogen, the Kaoko belt, Namibia. Journal of Petrology, 44, 679-711.

Gray, D.R., Foster, D.A., Meert, J.G., Goscombe, B.D., Armstrong, R., Trouw, R.A.J., Passchier, C.W., 2008. A Damara Orogen perspective on the assembly of southwestern Gondwana. In: Pankhurst, R.J., Trouw, R.A.J., Brito Neves, B.B., De Wit, M.J. (Eds.), West Gondwana: pre-Cenozoic correlations across the South Atlantic region. Geological Society of London, Special Publication 294, 257-278.

Green, P.F., Machado, V., 2017. Pre-rift and synrift exhumation, post-rift subsidence and exhumation of the onshore Namibe Margin of Angola revealed from apatite fission track analysis. In: Sabato-Ceraldi, T., Hodgkinson, R.A., Backe, G. (Eds.), Petroleum Geoscience of the West Africa Margin. Geological Society London, Special Publication 438, 99-118.

Griffin, W.L., Powell, W.J., Pearson, N.J., O’Reilly, S.Y., 2008. GLITTER: data reduction software for laser ablation ICP-MS. Laser Ablation-ICP-MS in the earth sciences. Mineralogical association of Canada short course series, 40, 204-207

Guilcher, A., Medeiros, C.A., Matos, J.E., Oliveira, J.T., 1974. Les restingas (fléches littorales) d'Angola, spécialment celles du sud et du centre. Finisterra, 9, 117-211.

Guiraud, M., Buta-Neto, A., Quesne, D., 2010. Segmentation and differential post-rift uplift at the Angola margin as recorded by the transform-rifted Benguela and oblique-to-orthogonal-rifted Kwanza basins. Marine and Petroleum Geology, 27, 1040-1068.

Haddon, I.G., McCarthy, T.S., 2005. The Mesozoic-Cenozoic interior sag basins of Central Africa: the LateCretaceous-Cenozoic Kalahari and Okavango basins. Journal of African Earth Sciences, 43, 316-333.

Hardman-Mountford, N.J., Richardson, A.J., Agenbag, J.J., Hagen, E., Nykjaer, L., Shillington, F.A., Villacastin, C., 2003. Ocean climate of the South East Atlantic observed from satellite data and wind models. Progress in Oceanography, 59, 181-221.

Heilbron, M., Valeriano, C.M., Tassinari, C.C.G., Almeida, J., Tupinambá, M., Siga, O., Trouw, R., 2008. Correlation of Neoproterozoic terranes between the Ribeira Belt, SE Brazil and its African counterpart: comparative tectonic evolution and open questions. In: Pankhurst, R.J., Trouw, R.A.J., Brito Neves, B.B., Wit, M.J. (Eds.), West Gondwana: Pre-Cenozoic Correlations Across the South Atlantic Region. Geological Society London, Special Publication 294, pp. 211-237. 
1160

1161

1162

1163

1164

1165

1166

1167

1168

1169

1170

1171

1172

1173

1174

1175

1176

1177

1178

1179

1180

1181

1182

1183

1184

1185

1186

1187

1188

1189

1190

1191

1192

1193

1194

1195

1196

1197

1198

1199

1200

1201

Hijmans, R.J., Cameron, S.E., Parra, J.L., Jones, P.G., Jarvis, A., 2005. Very high resolution interpolated climate surfaces for global land areas. International Journal of Climatology, 25, 1965-1978.

Holisticos, 2012. Environmental impact study for the rehabilitation and expansion of the Cambambe hydroelectric power plant. https://www.miga.org/documents/Angola_Cambambe_HPP_EIS.pdf

Hubert, J.F., 1962. A zircon-tourmaline-rutile maturity index and the interdependence of the composition of heavy mineral assemblages with the gross composition and texture of sandstones. Journal of Sedimentary Petrology, 32, 440-450.

Hudec, M.R., Jackson, M.P.A., 2002. Structural segmentation, inversion, and salt tectonics on a passive margin: evolution of the Inner Kwanza Basin, Angola. Geological Society of America Bulletin, 114, $1222-1244$.

Hudec, M.R., Jackson, M.P.A., 2004. Regional restoration across the Kwanza Basin, Angola: salt tectonics triggered by repeated uplift of a metastable passive margin. American Association of Petroleum Geologists Bulletin, 88, 971-990.

Ingersoll, R.V., Bullard, T.F., Ford, R.L., Grimm, J.P., Pickle, J.D., Sares, S.W., 1984. The effect of grain size on detrital modes: a test of the Gazzi-Dickinson point-counting method. Journal of Sedimentary Petrology, 54, 103-116.

Jackson, M.P.A, Hudec, M.R., Hegarty, K.A., 2005. The great West African Tertiary coastal uplift: fact or fiction? A perspective from the Angolan divergent margin. Tectonics, 24, TC6014, doi:10.1029/2005TC001836.

Jacobs, J., Pisarevsky, S., Thomas, R.J., Becker, T., 2008. The Kalahari Craton during the assembly and dispersal of Rodinia. Precambrian Research, 160, 142-158.

James, C.W., Mack, G.H., Suttner, L.J., 1981. Relative alteration of microcline and sodic plagioclase in semi-arid and humid climates. Journal of Sedimentary Petrology, 51, 151-164.

Johnsson, M.J., 1993. The system controlling the composition of clastic sediments. In: Johnsson, M.J., Basu, A. (Eds.), Processes controlling the composition of clastic sediments. Geological Society of America, Special Paper 284, pp. 1-19.

Johnsson, M.J., Stallard, R.F., Meade, R.H., 1988. First-cycle quartz arenites in the Orinoco River basin: Venezuela and Colombia. The Journal of Geology, 96, 263-277.

Johnsson, M.J., Stallard, R.F., Lundberg, N., 1991. Controls on the composition of fluvial sands from a tropical weathering environments: sands of the Orinoco River drainage basin, Venezuela and Colombia. Geological Society of America Bulletin, 103, 1622-1647.

Köhn, M., 1928. Bemerkungen zur mechanischen Bodenanalyse. III. Ein neuer Pipettapparat. Zeitschrift für Pflanzenernährung, Düngung, Bodenkunde, 11, 50-54.

Komar, P.D., 2007. The entrainment, transport and sorting of heavy minerals by waves and currents In: Mange, M.A., Wright, D.T. (Eds.), Heavy minerals in use. Elsevier, Amsterdam, Developments in Sedimentology Series, 58, pp. 3-48.

Komar, P.D., Li, Z., 1988. Application of grain-pivoting and sliding analyses to selective entrainment of gravel and to flow-competence evaluations. Sedimentology, 35, 681-695.

Kostianoy, A.G., Lutjeharms, J.R.E., 1999. Atmospheric effects in the Angola-Benguela frontal zone. Journal of Geophysical Research: Oceans, 104, 20963-20970.

Lancaster, N., 2002. How dry was dry? Late Pleistocene palaeoclimates in the Namib desert. Quaternary Science Reviews, 21, 769-782. 
Lass, H.U., Mohrholz, V., 2008. On the interaction between the subtropical gyre and the Subtropical Cell on the shelf of the SE Atlantic. Journal of Marine Systems, 74, 1-43-

Leturmy, P., Lucazeau, F., Brigaud, F., 2003. Dynamic interactions between the Gulf of Guinea passive margin and the Congo River drainage basin: 1. Morphology and mass balance. Journal of Geophysical Research, 108(B8), 2383, doi:10.1029/2002JB001927.

Lopes, F.C., Pereira, A.J., Mantas, V.M., Mpengo, H.K., 2016. Morphostructural characterization of the western edge of the Huila Plateau (SW Angola), based on remote sensing techniques. Journal of African Earth Sciences, 117, 114-123.

Macgregor, D.S., 2013. Late Cretaceous-Cenozoic sediment and turbidite reservoir supply to South Atlantic margins. Geological Society London, Special Publications, 369, 109-128.

Marton, G.L., Tari, G.C., Lehmann, C.T., 2000. Evolution of the Angolan passive margin, West Africa, with emphasis on post-salt structural styles. In: Mohriak, W., Talwani, M. (Eds.), Atlantic Rifts and Continental Margins. American Geophysical Union, Geophysical Monograph Series, 115, pp. 129-149.

Marzoli, A., Melluso, L., Morra, V., Renne, P.R., Sgrosso, I., D'Antonio, M., Morais, L.D., Morais, E.A.A., Ricci, G., 1999. Geochronology and petrology of Cretaceous basaltic magmatism in the Kwanza basin (western Angola), and relationships with the Paranà-Etendeka continental flood basalt province. Journal of Geodynamics , 28, 341-356.

Masse, P., Laurent, O., 2016. Geological exploration of Angola from Sumbe to Namibe: a review at the frontier between geology, natural resources and the history of geology. Comptes Rendus Geoscience, $348,80-88$.

Mayer, A., Hofmann, A.W., Sinigoi, S., Morais, E., 2004. Mesoproterozoic Sm-Nd and U-Pb ages for the Kunene Anorthosite Complex of SW Angola. Precambrian Research, 133, 187-206.

McBride, E.F., 1985, Diagenetic processes that affect provenance determinations in sandstones. In: Zuffa, G.G. (Ed.), Provenance of Arenites. Reidel, Dordrecht, NATO ASI Series, 148, 95-113.

McCourt, S., Armstrong, R.A., Jelsma, H., Mapeo, R.B.M, 2013. New U-Pb SHRIMP ages from the Lubango region, SW Angola: insights into the Palaeoproterozoic evolution of the Angolan Shield, southern Congo Craton, Africa. Journal of the Geological Society London, 170, 353-363.

McDonough, W.F., Sun, S.S., 1995. The composition of the Earth. Chemical Geology, 120, 223-253.

Mohriak W.U., Rosendahl, B.R., 2003. Transform zones in the South Atlantic rifted continental margins. In: Storti, F., Holdsworth, R.E., Salvini, F. (Eds), Intraplate Strike-Slip Deformation Belts. Geological Society London, Special Publication 210, pp. 211-228.

Morton, A.C., Hallsworth, C., 2007. Stability of detrital heavy minerals during burial diagenesis. In: Mange, M.A., Wright, D.T. (Eds.), Heavy Minerals in Use. Developments in Sedimentology Series, 58, 215245.

Moulin, M., Aslanian, D., Olivet, J.L., Contrucci, I., Matias, L., Géli, L., Klingelhoefer, F., Nouzé, H., Réhault, J.P., Unternehr, P., 2005. Geological constraints on the evolution of the Angolan margin based on reflection and refraction seismic data (ZaïAngo project). Geophysical Journal International, 162, 793-810.

Moulin, M., Aslanian, D., Unternehr, P., 2010. A new starting point for the South and Equatorial Atlantic Ocean. Earth-Science Reviews, 98, 1-37.

Nesbitt, H.W., Young, G.M., 1982. Early Proterozoic climates and plate motions inferred from major element chemistry of lutites. Nature, 299, 715-717.

Neto, M.M.G.N., 1960. Estratigrafia da região de entre Benguela e o Cabo de S. ${ }^{\text {ta }}$ Maria (Angola). Revista do Museu e Laboratorio Mineralogico e Geologico, Faculdade de Ciencias de Coimbra, 19 p. 
Parker, A. 1970. An index of weathering for silicate rocks. Geological Magazine, 107, 501-504.

Pereira, E., Tassinari, C.C.G., Rodrigues, J.F., Van-Dúnem, M.V., 2011. New data on the deposition age of the volcano-sedimentary Chela Group and its Eburnean basement: implications to post-Eburnean crustal evolution of the SW of Angola. Comunicações Geológicas, 98, 29-40.

Péron-Pinvidic, G., Manatschal, G., Masini, E., Sutra, E., Flament J.M., Haupert, I., Unternehr, P., 2017. Unravelling the along-strike variability of the Angola-Gabon rifted margin: a mapping approach. In: Sabato-Ceraldi, T., Hodgkinson, R.A., Backe, G. (Eds.), Petroleum Geoscience of the West Africa Margin. Geological Society London, Special Publication 438, 49-76.

Potter, P.E., 1994. Modern sands of South America: composition, provenance and global significance. Geologische Rundschau, 83, 212-232.

Pritchard, D., Roberts, G.G., White, N.J., Richardson, C.N., 2009. Uplift histories from river profiles. Geophysical research letters, 36, L24301, doi:10.1029/2009GL040928.

Quesne, D., Buta-Neto, A., Benard, D., Guiraud, G., 2009. Distribuition of Albian clastic deposits in the Benguela basin (Angola): evidence of a Benguela palaeocurrent? Bulletin de la Société Géologique de France, 180, 117-129.

Renne, P.R., Glen, J.M., Milner, S.C., Duncan, A.R., 1996. Africa age of Etendeka flood volcanism and associated intrusions in southwestern Africa. Geology, 24, 659-662.

Roberts, G.G., White, N., 2010. Estimating uplift rate histories from river profiles using African examples. Journal of Geophysical Research, 115, B02406. doi:10.1029/2009JB006692.

Rudnick, R.L., Gao, S., 2003. Composition of the continental crust. In: Rudnick, R.L., Holland, H.D., Turekian, K.K. (Eds.), Treatise on geochemistry, 3, The crust. Elsevier Pergamon, Oxford, pp. 1-64.

Russell, R.D., 1937. Mineral composition of Mississippi River sands. Geological Society of America Bulletin, 48, 1307-1348.

Sabato-Ceraldi, T., Green, D., 2017. Evolution of the South Atlantic lacustrine deposits in response to Early Cretaceous rifting, subsidence and lake hydrology. In: Sabato-Ceraldi, T., Hodgkinson, R.A., Backe, G. (Eds.), Petroleum Geoscience of the West Africa Margin. Geological Society, London, Special Publication 438, 77-98.

Schlüter, T. 2008. Geological Atlas of Africa. Springer, Heidelberg, 307 p.

Schneider, S., Hornung, J., Hinderer, M., Garzanti, E., 2016. Petrography and geochemistry of modern river sediments in an equatorial environment (Albertine Rift, Uganda) - Implications for weathering and provenance. In: Caracciolo, L., Garzanti, E., von Eynatten, H., Weltje, G.J. (Eds.), Sediment generation and provenance: processes and pathways. Sedimentary Geology, 336, 106-119.

Schulz, H.D., Beese, D., Breitzke, M., Brück, L., Brügger, B., Dahmke, A., Dehning, K., Diekamp, V., Dünner, B., Ehrhardt, I., Gerlach, H., Giese, M., Glud, R., Gumprecht, R., Gundersen, J., Henning, R., Hinrichs, S., Petermann, H., Richter, M., Sagemann, J., Schmidt, W., Schneider, R., Scholz, M., Segl, M., Werner, U., Zabel, M., 1992. Bericht und erste Ergebnisse über die Meteor-Fahrt M20/2, Abidjan-Dakar, 27.12.19913.2.1992. Berichte aus dem Fachbereich Geowissenschaften der Universität Bremen, 025. Department of Geosciences, Bremen University, 25, 175 p.

Schulz, H.D., Adegbie, A.T., Boehme, S., Brune, A., Däumler, K., Dehning, K. ..., Funk, J., 1998. Report and preliminary results of METEOR-Cruise M 41/1, Málaga - Libreville, 13.2.-15.3.1998 with partial results of METEOR CRUISE 41/2 Libreville-Vitoria, 18.03.1998-15.4.1998. Berichte aus dem Fachbereich Geowissenschaften der Universität Bremen, 114, 124 p.

Séranne, M., Anka, Z., 2005. South Atlantic continental margins of Africa: a comparison of the tectonic vs climate interplay on the evolution of equatorial west Africa and SW Africa margins. Journal of African 
Earth Sciences, 43, 283-300.

Shannon, L.V., Nelson, G., 1996. The Benguela: large scale features and processes and system variability. In: Wefer, G., Berger, W.H., Siedler, G., Webb, D.J. (Eds.), The South Atlantic: past and present circulation. Springer, Berlin, pp. 163-210.

Shukri, N.M., 1950. The mineralogy of some Nile sediments. Quarterly Journal of the Geological Society London, 105, 511-534.

Strganac, C., Salminen, J., Jacobs, L.L., Polcyn, M.J., Ferguson, K.M., Mateus, O., Schulp, A.S., Morais, M.L., Tavares; T. da S., Gonçalves, A.O., 2014. Carbon isotope stratigraphy, magnetostratigraphy, and ${ }^{40} \mathrm{Ar} /{ }^{39} \mathrm{Ar}$ age of the Cretaceous South Atlantic coast, Namibe Basin, Angola. Journal of African Earth Sciences, 99, 452-462.

Tack, L., Wingate, M.T.D., Liégeois, J.P., Fernandez-Alonso, M., Deblond, A., 2001. Early Neoproterozoic magmatism (1000-910 Ma) of the Zadinian and Mayumbian Groups (Bas-Congo): onset of Rodinia rifting at the western edge of the Congo craton. Precambrian Research, 110, 277-306.

Taylor, S.R., McLennan, S.M., 1995. The geochemical evolution of the continental crust. Reviews of Geophysics, 33, 241-265.

Vaughan, A.P., Pankhurst, R.J., 2008. Tectonic overview of the West Gondwana margin. Gondwana Research, 13, 150-162.

Velbel, M.A., Saad, M.K., 1991. Palaeoweathering or diagenesis as the principal modifier of sandstone framework composition? A case study from some Triassic rift-valley redbeds of eastern North America. Geological Society London, Special Publication 57, 91-99.

Vermeesch, P., Fenton, C.R., Kober, F., Wiggs, G.F.S., Bristow, C.S., Xu, S., 2010. Sand residence times of one million years in the Namib Sand Sea from cosmogenic nuclides. Nature Geosciences, 3, 862-865.

Vermeesch, P., Resentini, A., Garzanti, E., 2016. An R package for statistical provenance analysis. Sedimentary Geology, 336, 14-25.

Vermeesch, P., Rittner, M., Petrou, E., Omma, J., Mattinson, C, Garzanti, E., 2017. High throughput petrochronology and sedimentary provenance analysis by automated phase mapping and LAICPMS. Geochemistry, Geophysics, Geosystems, 18, doi.org/10.1002/2017GC007109.

Wefer, G., Bleil, U., Müller, P.J., Schulz, H.D., Berger, W.H., Brathauer, U., Brück, L., Dahmke, A., Dehning, K., Durate-Morais, M.L., Fürsich, F., Hinrichs, S., Klockgeter, K., Kölling, A., Kothe, C., Makaya, J.F., Oberhänsli, H., Oschmann, W., Posny, J., Rostek, F., Schmidt, H., Schneider, R.R., Segl, M., Sobiesiak, M., Soltwedel, T., Spieß, V., 1988. Bericht über die Meteor-Fahrt M6-6, Libreville - Las Palmas, 18.2.1988 - 23.3.1988. Berichte aus dem Fachbereich Geowissenschaften der Universität Bremen, 003. Department of Geosciences, Bremen University, 3, 97 p.

White, N., 2016. Geodynamics: surface sculpting by hidden agents. Nature Geoscience, 9, 867-869. 

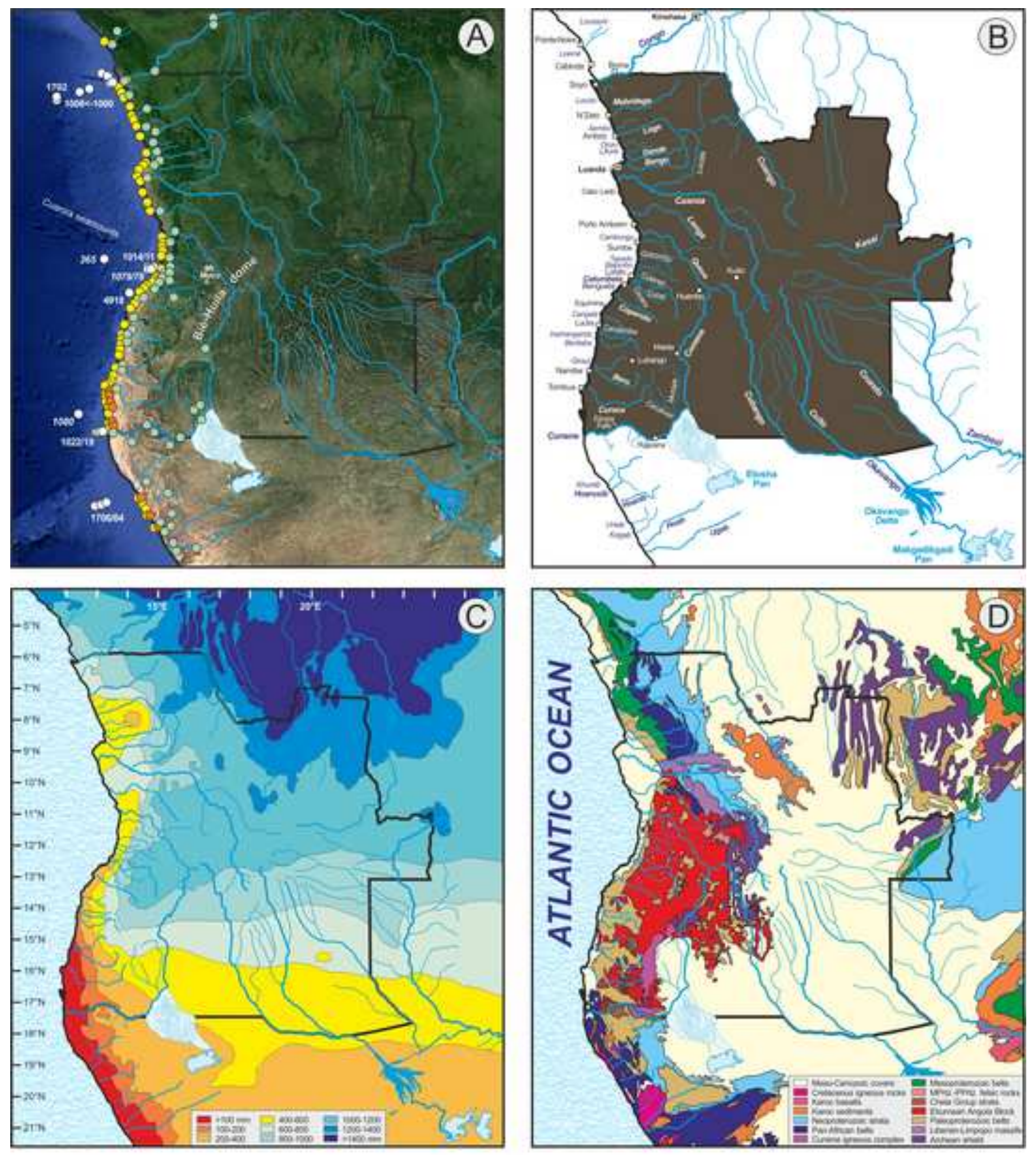

Figure 1 Angola 


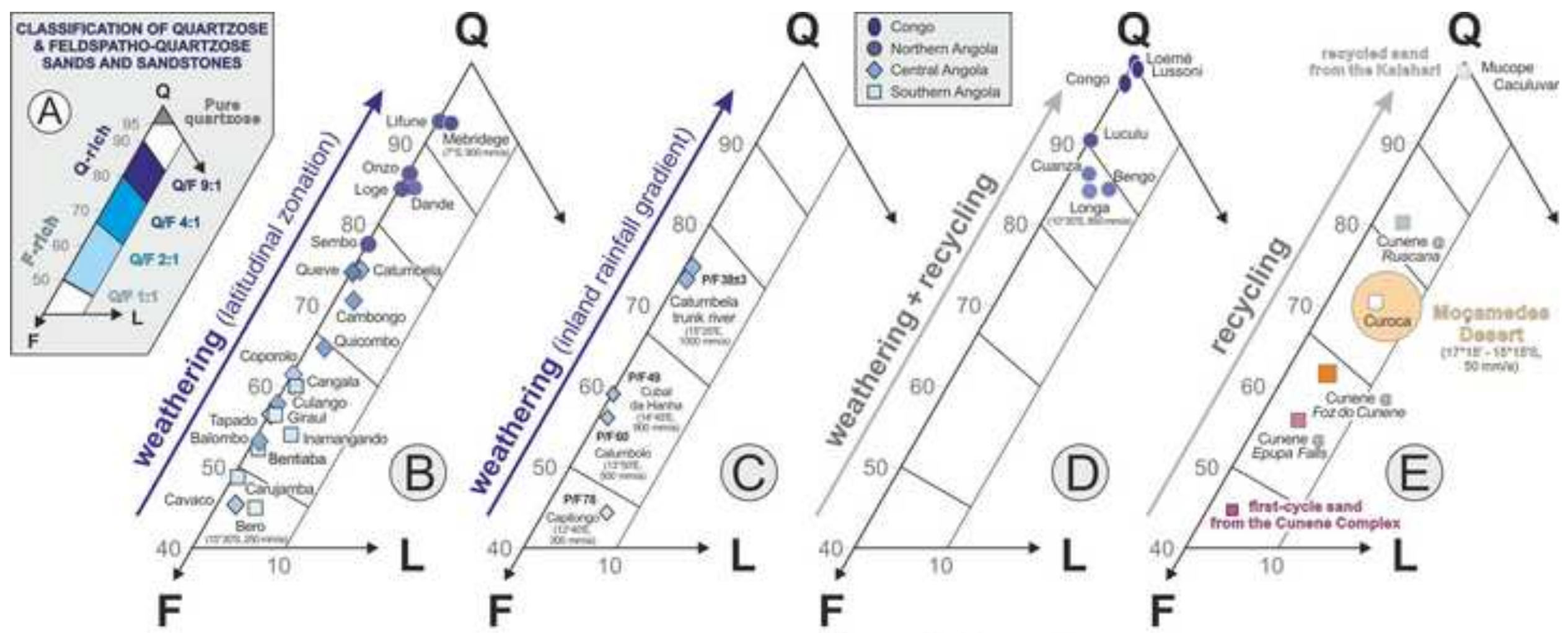

Figure 2 Angola 


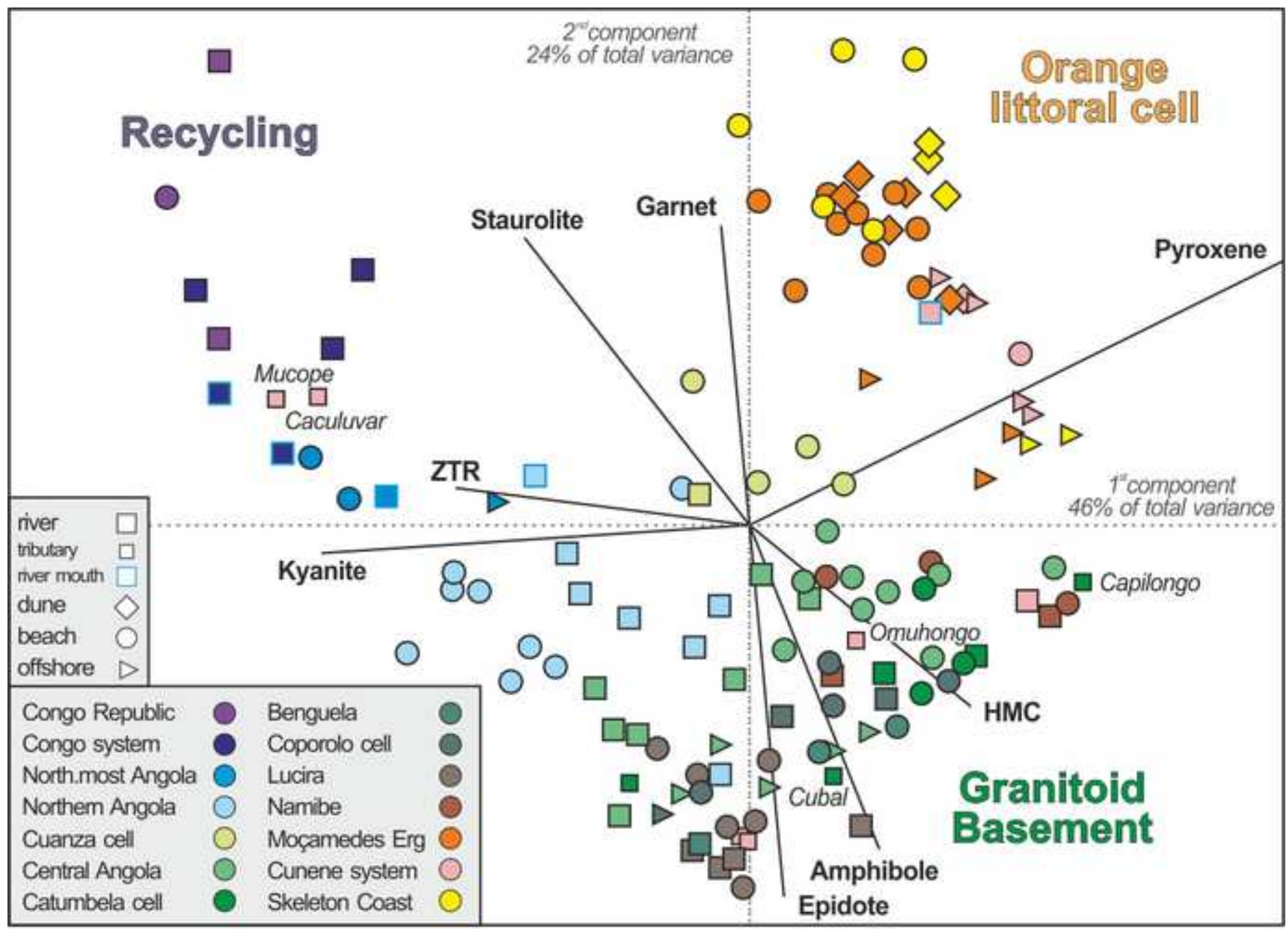

Figure 3 Angola 
Click here to download high resolution image
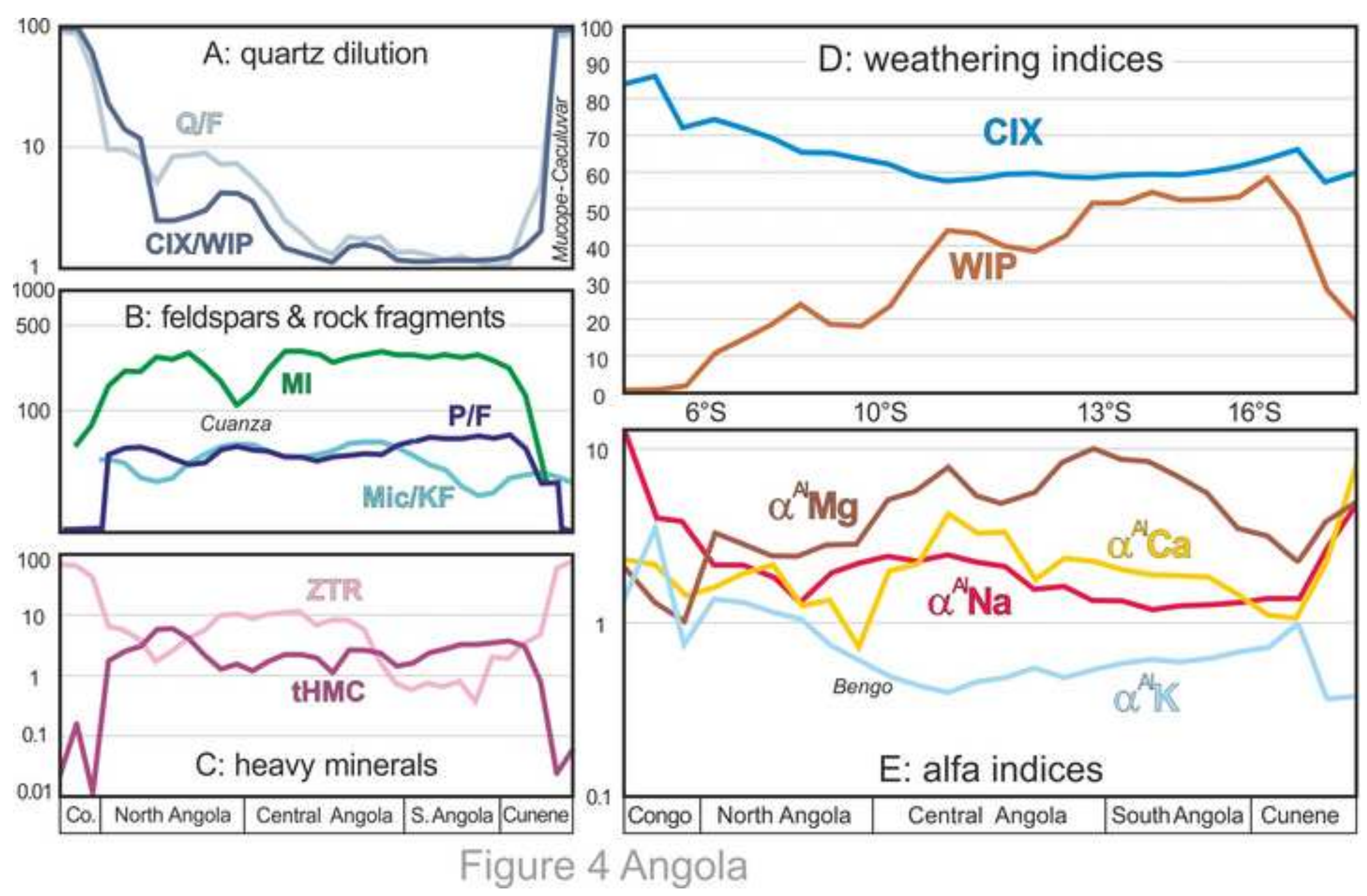

Figure 4 Angola 
Click here to download high resolution image

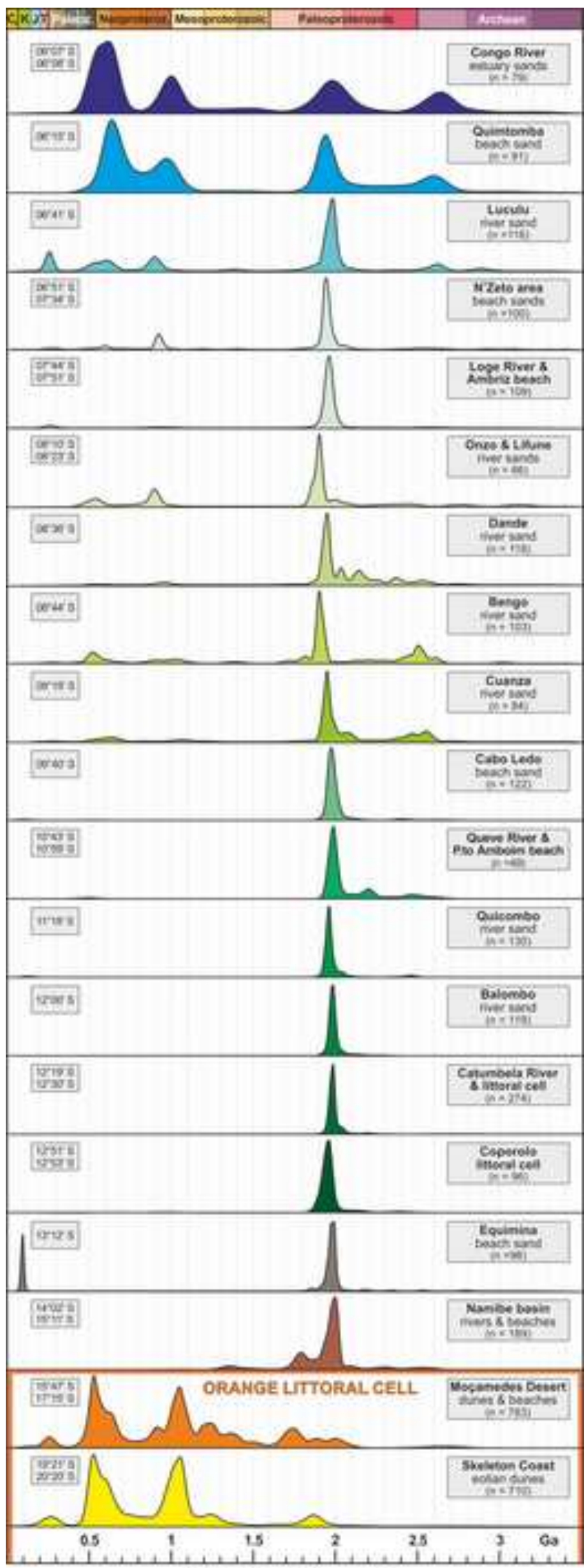

Figure 5 Angola 


\section{Figure 6}

Click here to download high resolution image

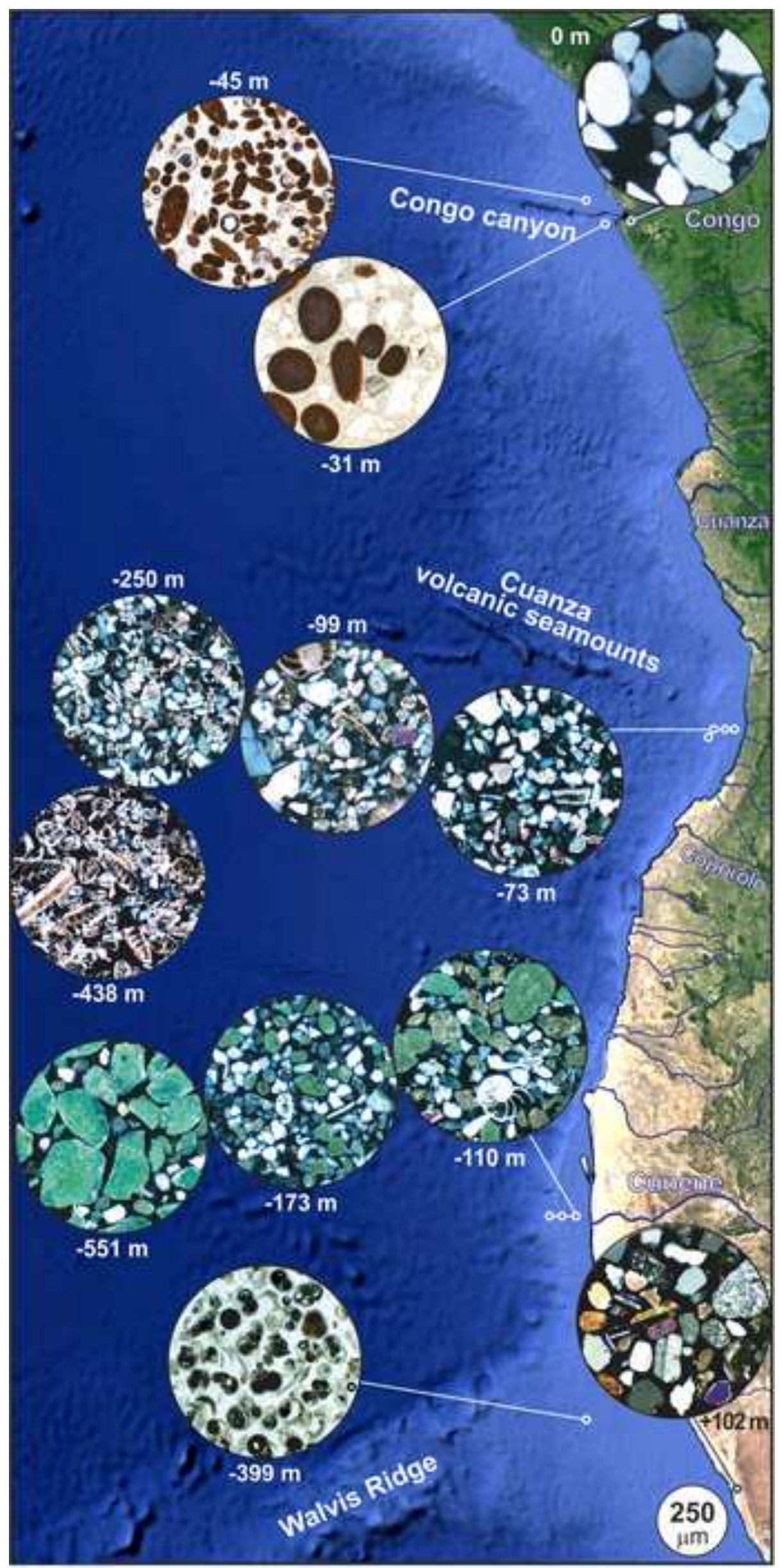

Figure 6 Angola 

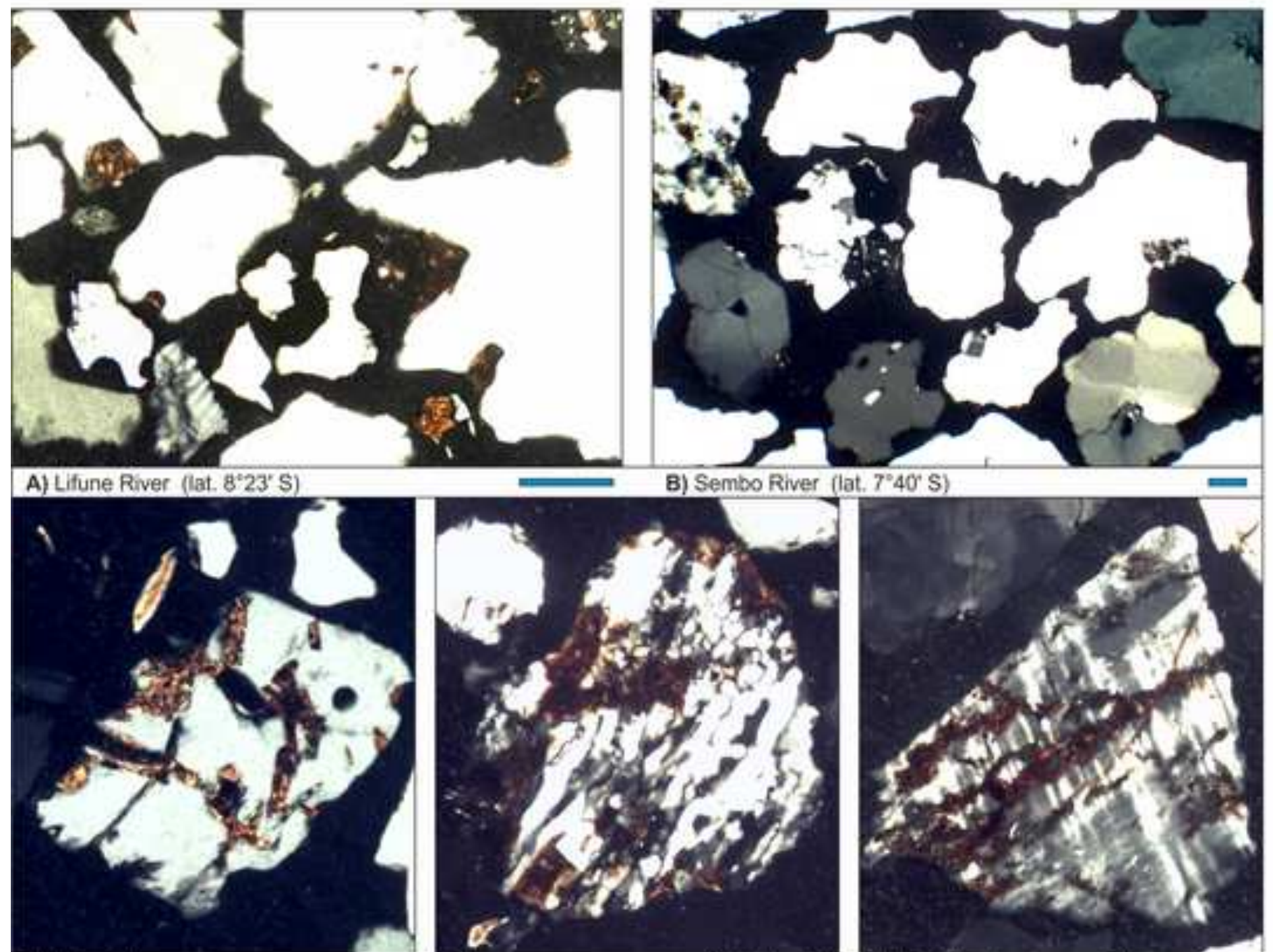

$=$

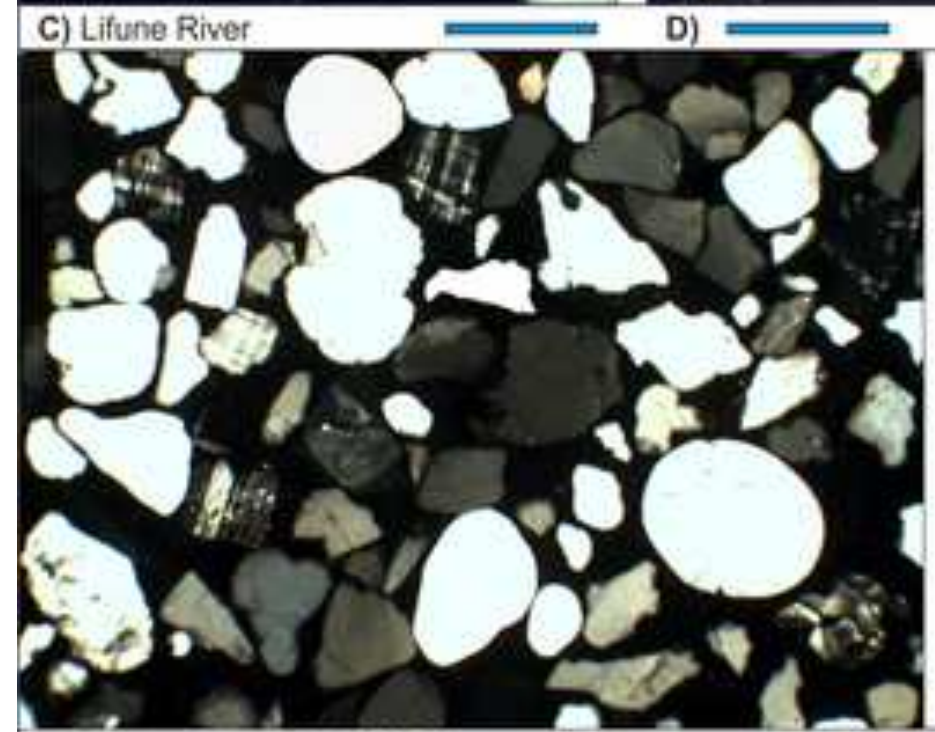

F) Cuanza River (lat. 9'12' S)

를

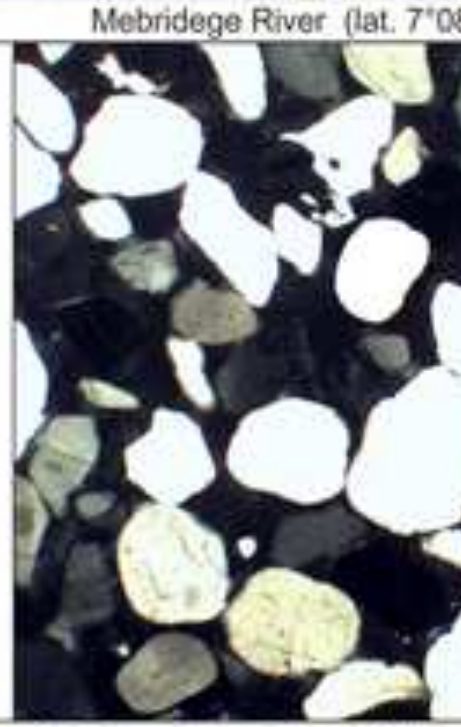

'085 S)

E)

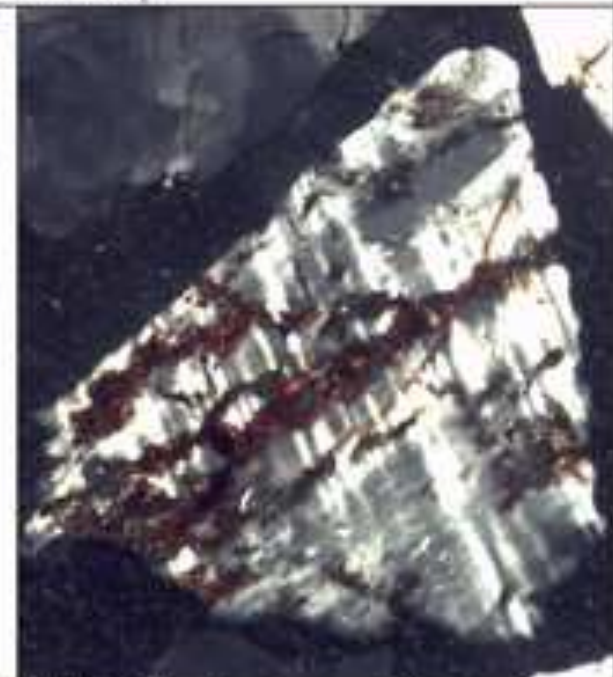

G) Congo River (lat. $\left.4^{\circ} 17^{\prime}\right)$

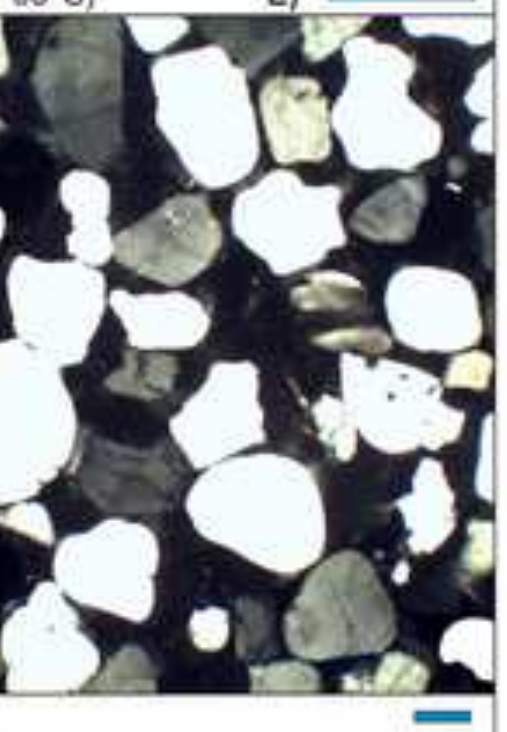

Figure 7 Angola 
Click here to download high resolution image

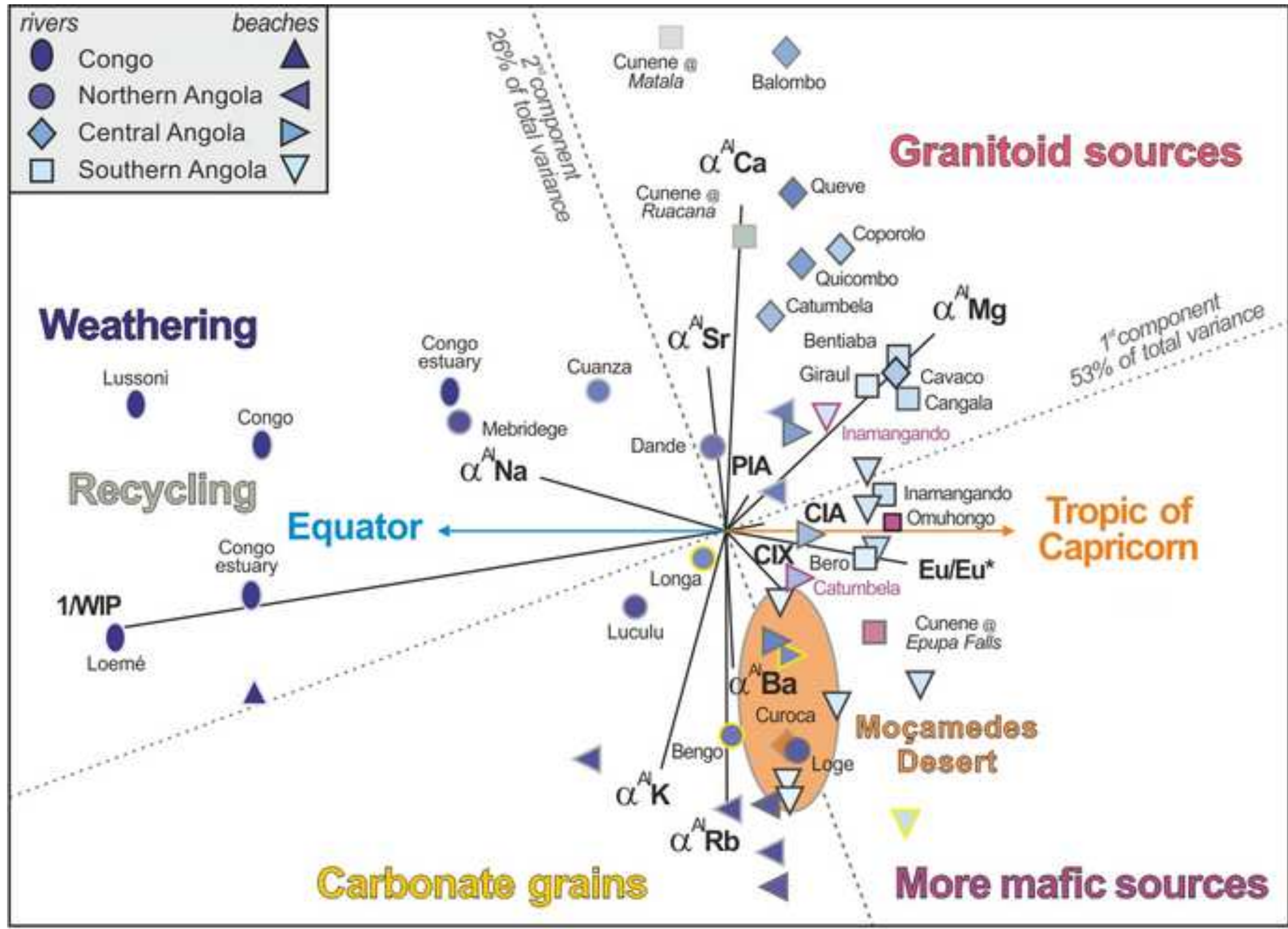

Figure 8 Angola 
Table 1

Click here to download Table: Table 1 Angola PTHMCHI.pdf

Table 1. Angola Margin

\begin{tabular}{|c|c|c|c|c|c|c|c|c|c|c|c|c|c|c|c|c|c|c|c|c|c|c|c|c|c|}
\hline & $\mathrm{N}^{\circ}$ & Qz & $\mathrm{KF}$ & $\mathrm{PI}$ & Lvm & Lsm & $\mathrm{Lm}$ & mica & $\mathrm{HM}$ & & $\mathrm{MI}^{*}$ & tHMC & ZTR & $\mathrm{Ep}$ & Grt & $\mathrm{St}$ & $\mathrm{Ky}$ & Amp & $\mathrm{Px}$ & \&tHM & & $\mathrm{CIA}$ & $\mathrm{CIX}$ & WIP & $\mathrm{a}^{\mathrm{Al}} \mathrm{Na}$ \\
\hline \multicolumn{26}{|l|}{ RIVER SANDS } \\
\hline Repubblic of Congo & 2 & 99 & 0 & 0 & 0 & 0 & 0 & 0 & 1 & 100.0 & & 0.2 & 74 & 5 & 4 & 8 & 6 & 0 & 0 & 3 & 100.0 & 87 & 86 & 0.3 & 6.2 \\
\hline & & 0 & 0 & 0 & 0 & 0 & 0 & 0 & 0 & & & 0.2 & 4 & 4 & 6 & 3 & 6 & 0 & 0 & 2 & & 10 & 6 & 0.3 & 0.2 \\
\hline Congo & 3 & 98 & 1 & 0 & 0 & 0 & 0 & 0 & 1 & 100.0 & & 0.2 & 57 & 13 & 2 & 14 & 7 & 3 & 0 & 3 & 100.0 & 63 & 72 & 1 & 3.9 \\
\hline & & 1 & 1 & 0 & 0 & 0 & 0 & 0 & 1 & & & 0.2 & 18 & 7 & 1 & 4 & 4 & 2 & 0 & 2 & & & & & \\
\hline Congo Estuary & 2 & 98 & 1 & 1 & 0 & 0 & 0 & 0 & 0 & 100.0 & & 0.1 & 41 & 14 & 3 & 7 & 20 & 12 & 0 & 4 & 100.0 & 81 & 85 & 2 & 7.8 \\
\hline & & 0 & 0 & 0 & 0 & 0 & 0 & 0 & 0 & & & 0.1 & 8 & 8 & 0 & 2 & 18 & 2 & 0 & 3 & & 12 & 13 & 2 & 7.0 \\
\hline Luculu & 1 & 86 & 4 & 5 & 0 & 0 & 0 & 0 & 5 & 100.0 & & 3.8 & 7 & 30 & 33 & 2 & 15 & 13 & 0 & 1 & 100.0 & 62 & 74 & 11 & 2.2 \\
\hline Mebridege & 1 & 93 & 3 & 3 & 0 & 1 & 1 & 0 & 0 & 100.0 & 183 & 0.02 & 9 & 8 & 1 & 0 & 3 & 71 & 1 & 7 & 100.0 & 70 & 75 & 4 & 3.2 \\
\hline Sembo & 1 & 77 & 14 & 8 & 0 & 0 & 0 & 0 & 0 & 100.0 & & 1.1 & 2 & 21 & 2 & 0 & 1 & 72 & 1 & 0 & 100.0 & & & & \\
\hline Loge & 1 & 76 & 6 & 8 & 0 & 0 & 0 & 0 & 10 & 100.0 & & 7.3 & 1 & 70 & 2 & 0 & 0 & 26 & 0 & 2 & 100.0 & 50 & 67 & 27 & 1.1 \\
\hline Onzo & 1 & 81 & 7 & 6 & 0 & 0 & 0 & 0 & 6 & 100.0 & 325 & 5.8 & 1 & 27 & 7 & 0 & 6 & 57 & 2 & 0 & 100.0 & & & & \\
\hline Lifune & 1 & 87 & 5 & 1 & 0 & 0 & 0 & 2 & 5 & 100.0 & & 3.3 & 7 & 35 & 11 & 0 & 11 & 34 & 1 & 0 & 100.0 & & & & \\
\hline Dande & 1 & 80 & 8 & 6 & 0 & 0 & 1 & 4 & 2 & 100.0 & 275 & 1.3 & 6 & 48 & 6 & 0 & 4 & 36 & 1 & 1 & 100.0 & 58 & 65 & 24 & 1.3 \\
\hline Bengo & 1 & 82 & 6 & 5 & 0 & 4 & 0 & 0 & 4 & 100.0 & & 2.1 & 6 & 30 & 13 & 1 & 10 & 37 & 1 & 1 & 100.0 & 33 & 64 & 20 & 1.5 \\
\hline Cuanza & 1 & 87 & 5 & 6 & 0 & 1 & 0 & 0 & 0 & 100.0 & & 0.3 & 18 & 52 & 5 & 0 & 2 & 15 & 7 & 1 & 100.0 & 54 & 66 & 10 & 2.9 \\
\hline Longa & 1 & 82 & 6 & 6 & 1 & 2 & 0 & 0 & 3 & 100.0 & & 2.1 & 8 & 85 & 0 & 0 & 0 & 6 & 0 & 1 & 100.0 & 38 & 62 & 23 & 2.3 \\
\hline Queve & 1 & 73 & 16 & 9 & 0 & 0 & 0 & 1 & 1 & 100.0 & & 0.6 & 1 & 43 & 2 & 0 & 0 & 51 & 0 & 2 & 100.0 & 55 & 59 & 37 & 2.1 \\
\hline Cambongo & 1 & 68 & 13 & 14 & 2 & 0 & 0 & 1 & 2 & 100.0 & 425 & 1.4 & 22 & 51 & 1 & 0 & 0 & 18 & 6 & 1 & 100.0 & & & & \\
\hline Quicombo & 1 & 60 & 21 & 10 & 0 & 1 & 1 & 2 & 5 & 100.0 & 340 & 3.2 & 10 & 64 & 3 & 0 & 0 & 15 & 2 & 6 & 100.0 & 51 & 57 & 43 & 2.3 \\
\hline Tapado & 1 & 56 & 27 & 16 & 0 & 0 & 0 & 1 & 0 & 100.0 & & 0.4 & 3 & 78 & 1 & 0 & 0 & 17 & 0 & 0 & 100.0 & & & & \\
\hline Balombo & 1 & 53 & 26 & 19 & 0 & 0 & 0 & 1 & 0 & 100.0 & & 0.5 & 8 & 89 & 0 & 0 & 0 & 3 & 1 & 0 & 100.0 & 55 & 57 & 52 & 3.1 \\
\hline Culango & 1 & 57 & 23 & 18 & 0 & 0 & 0 & 1 & 1 & 100.0 & & 0.9 & 14 & 71 & 0 & 0 & 0 & 14 & 0 & 1 & 100.0 & & & & \\
\hline Catumbela & 2 & 69 & 15 & 9 & 0 & 0 & 0 & 0 & 6 & 100.0 & 317 & 2.2 & 4 & 59 & 0 & 0 & 0 & 18 & 14 & 4 & 100.0 & 54 & 59 & 32 & 1.9 \\
\hline & & 5 & 2 & 0 & 0 & 0 & 0 & 0 & 7 & & & 1.8 & 3 & 14 & 0 & 0 & 0 & 4 & 11 & 5 & & & & & \\
\hline Cavaco & 1 & 43 & 26 & 24 & 0 & 0 & 1 & 1 & 3 & 100.0 & 350 & 1.9 & 1 & 71 & 0 & 0 & 0 & 24 & 0 & 3 & 100.0 & 52 & 59 & 48 & 1.3 \\
\hline Coporolo & 2 & 61 & 20 & 16 & 0 & 0 & 0 & 1 & 2 & 100.0 & 300 & 1.2 & 2 & 67 & 0 & 0 & 0 & 28 & 3 & 1 & 100.0 & 53 & 58 & 48 & 1.7 \\
\hline & & 1 & 4 & 2 & 0 & 0 & 0 & 0 & 1 & & & 0.7 & 1 & 0 & 0 & 0 & 0 & 0 & 3 & 1 & & & & & \\
\hline Cangala & 1 & 59 & 13 & 25 & 0 & 0 & 1 & 0 & 2 & 100.0 & 267 & 1.8 & 0 & 76 & 0 & 0 & 0 & 22 & 0 & 2 & 100.0 & 52 & 58 & 57 & 1.1 \\
\hline Carujamba & 1 & 48 & 21 & 29 & 0 & 0 & 0 & 0 & 2 & 100.0 & & 1.5 & 0 & 63 & 0 & 0 & 0 & 35 & 0 & 1 & 100.0 & & & & \\
\hline Inamangando & 1 & 52 & 18 & 22 & 1 & 1 & 2 & 0 & 5 & 100.0 & 275 & 3.1 & 1 & 78 & 0 & 0 & 0 & 18 & 0 & 3 & 100.0 & 51 & 61 & 49 & 1.2 \\
\hline Bentiaba & 1 & 52 & 19 & 28 & 0 & 0 & 1 & 0 & 1 & 100.0 & 317 & 2.0 & 0 & 62 & 0 & 0 & 0 & 36 & 0 & 2 & 100.0 & 52 & 58 & 56 & 1.2 \\
\hline Giraul & 1 & 53 & 17 & 23 & 0 & 0 & 1 & 0 & 5 & 100.0 & 250 & 3.2 & 1 & 42 & 3 & 0 & 0 & 52 & 1 & 2 & 100.0 & 52 & 59 & 51 & 1.3 \\
\hline Bero & 1 & 42 & 16 & 32 & 0 & 1 & 2 & 1 & 5 & 100.0 & 350 & 3.2 & 0 & 21 & 0 & 0 & 0 & 60 & 16 & 2 & 100.0 & 51 & 62 & 51 & 1.2 \\
\hline Cunene@Matala & 1 & 75 & 19 & 6 & 0 & 0 & 0 & 0 & 0 & 100.0 & & 0.1 & 93 & 2 & 0 & 1 & 1 & 1 & 1 & 3 & 100.0 & 58 & 60 & 20 & 4.7 \\
\hline Cunene@Ruacana & 1 & 79 & 12 & 4 & 1 & 3 & 0 & 0 & 1 & 100.0 & & 0.7 & 5 & 32 & 1 & 0 & 0 & 55 & 0 & 7 & 100.0 & 51 & 57 & 28 & 2.7 \\
\hline Cunene@Epupa F. & 1 & 54 & 13 & 26 & 1 & 1 & 1 & 0 & 3 & 100.0 & 295 & 3.0 & 1 & 27 & 1 & 0 & 0 & 44 & 23 & 6 & 100.0 & 51 & 66 & 48 & 1.4 \\
\hline Cunene@Foz & 1 & 57 & 12 & 20 & 3 & 1 & 1 & 0 & 6 & 100.0 & 256 & 4.2 & 1 & 19 & 10 & 4 & 0 & 33 & 28 & 4 & 100.0 & & & & \\
\hline BEACH SANDS & 1 & 99 & 1 & 0 & 0 & 0 & 0 & 0 & 0 & 1000 & & 01 & 67 & 1 & 0 & 13 & 18 & 0 & 0 & 1 & 1000 & $>59$ & $>89$ & $<09$ & $>11$ \\
\hline & 1 & J & 1 & 0 & 0 & 0 & 0 & 0 & 0 & 100.0 & & 0.1 & 01 & 1 & 0 & 10 & 10 & 0 & 0 & 1 & 100.0 & > & $>0$ & C. & 1ו \\
\hline North.most Angola & 2 & 96 & 2 & 1 & 0 & 0 & 0 & 0 & 1 & 100.0 & & 0.6 & 9 & 35 & 13 & 7 & 16 & 19 & 0 & 1 & 100.0 & 42 & 72 & 7 & 1.8 \\
\hline & & 2 & 1 & 0 & 0 & 0 & 0 & 0 & 1 & & & 0.1 & 5 & 6 & 0 & 3 & 2 & 5 & 0 & 0 & & & & & \\
\hline Northern Angola & 8 & 83 & 6 & 3 & 0 & 1 & 0 & 0 & 6 & 100.0 & 425 & 4.4 & 4 & 43 & 19 & 1 & 6 & 24 & 1 & 2 & 100.0 & 39 & 67 & 23 & 1.2 \\
\hline & & 7 & 2 & 1 & 0 & 0 & 0 & 0 & 5 & & & 3.0 & 3 & 12 & 12 & 1 & 3 & 9 & 2 & 1 & & 5 & 2 & 4 & 0.2 \\
\hline Cuanza cell & 4 & 81 & 11 & 6 & 0 & 0 & 0 & 0 & 1 & 100.0 & & 0.9 & 4 & 51 & 3 & 1 & 1 & 22 & 14 & 4 & 100.0 & 39 & 55 & 27 & 1.5 \\
\hline & & 2 & 1 & 2 & 0 & 0 & 0 & 0 & 1 & & & 0.5 & 3 & 4 & 2 & 1 & 1 & 5 & 7 & 1 & & 2 & 0 & 3 & 0.1 \\
\hline Central Angola & 9 & 71 & 13 & 11 & 0 & 1 & 0 & 0 & 5 & 100.0 & 325 & 3.7 & 7 & 54 & 1 & 0 & 0 & 19 & 14 & 4 & 100.0 & 38 & 60 & 38 & 1.7 \\
\hline & & 3 & 2 & 2 & 0 & 1 & 0 & 0 & 3 & & & 2.3 & 5 & 8 & 1 & 0 & 1 & 4 & 9 & 4 & & 9 & 2 & 5 & 0.1 \\
\hline Catumbela cell & 3 & 61 & 14 & 13 & 0 & 0 & 1 & 1 & 10 & 100.0 & 374 & 6.2 & 4 & 63 & 1 & 0 & 0 & 19 & 13 & 1 & 100.0 & 47 & 61 & 43 & 1 \\
\hline & & 13 & 3 & 4 & 0 & 0 & 1 & 1 & 6 & & 66 & 4.4 & 2 & 6 & 1 & 0 & 0 & 6 & 5 & 0 & & & & & \\
\hline Benguela & 1 & 64 & 11 & 18 & 0 & 2 & 1 & 1 & 4 & 100.0 & 260 & 4.0 & 2 & 71 & 0 & 0 & 0 & 18 & 4 & 6 & 100.0 & & & & \\
\hline Coporolo cell & 4 & 65 & 19 & 12 & 0 & 0 & 0 & 0 & 3 & 100.0 & & 2.1 & 1 & 72 & 0 & 0 & 0 & 22 & 2 & 2 & 100.0 & & & & \\
\hline & & 4 & 6 & 3 & 0 & 0 & 0 & 0 & 3 & & & 1.7 & 1 & 7 & 0 & 0 & 0 & 7 & 1 & 0 & & & & & \\
\hline Southern Angola & 10 & 50 & 16 & 23 & 0 & 1 & 1 & 0 & 9 & 100.0 & 319 & 5.4 & 5 & 55 & 2 & 0 & 0 & 32 & 3 & 3 & 100.0 & 47 & 62 & 52 & 1.1 \\
\hline & & 6 & 5 & 7 & 0 & 1 & 1 & 0 & 8 & & 55 & 4.0 & 8 & 16 & 2 & 0 & 0 & 16 & 6 & 3 & & 4 & 2 & 6 & 0.2 \\
\hline Moçamedes Desert & 13 & 67 & 9 & 13 & 3 & 0 & 0 & 0 & 7 & 100.0 & 282 & 4.7 & 4 & 14 & 35 & 4 & 0 & 15 & 26 & 2 & 100.0 & 49 & 66 & 28 & 1.3 \\
\hline & & 6 & 3 & 2 & 1 & 1 & 0 & 0 & 7 & & 87 & 4.1 & 2 & 3 & 21 & 2 & 0 & 7 & 14 & 1 & & 3 & 2 & 2 & 0.1 \\
\hline Skeleton Coast Erg & 3 & 70 & 7 & 12 & 3 & 1 & 0 & 0 & 6 & 100.0 & 360 & 4.6 & 4 & 6 & 18 & 2 & 0 & 6 & 61 & 3 & 100.0 & 48 & 62 & 28 & 1.1 \\
\hline & & 1 & 1 & 3 & 1 & 0 & 0 & 0 & 1 & & & 0.5 & 2 & 2 & 8 & 1 & 0 & 2 & 3 & 3 & & 3 & 1 & 2 & 0.0 \\
\hline OFFSHOF & ENT & & & & & & & & & & & & & & & & & & & & & & & & \\
\hline Congo mouth & 1 & 82 & 5 & 3 & 0 & 0 & 0 & 0 & 10 & 100.0 & & 3.3 & 19 & 29 & 23 & 0 & 8 & 19 & 0 & 3 & 100.0 & & & & \\
\hline Tapado mouth & 4 & 44 & 26 & 20 & 0 & 2 & 0 & 1 & 6 & 100.0 & & 5.2 & 3 & 74 & 0 & 0 & 0 & 19 & 1 & 3 & 100.0 & & & & \\
\hline & & 5 & 0 & 5 & 0 & 1 & 0 & 2 & 1 & & & 1.0 & 1 & 7 & 0 & 0 & 0 & 6 & 1 & 1 & & & & & \\
\hline Coporolo mouth & 1 & 36 & 23 & 33 & 0 & 1 & 0 & 0 & 6 & 100.0 & & 3.1 & 0 & 78 & 1 & 0 & 0 & 15 & 0 & 5 & 100.0 & & & & \\
\hline Baia dos Tigres & 3 & & & & & & & & & & & & 4 & 19 & 3 & 0 & 0 & 15 & 50 & 8 & 100.0 & & & & \\
\hline & & & & & & & & & & & & & 2 & 4 & 4 & 0 & 1 & 6 & 16 & 4 & & & & & \\
\hline Cunene mouth & 4 & 69 & 7 & 13 & 1 & 3 & 0 & 0 & 5 & 100.0 & 146 & 5.8 & 3 & 13 & 3 & 0 & 0 & 8 & 65 & 7 & 100.0 & & & & \\
\hline & & 1 & 0 & 1 & 0 & 0 & 0 & 0 & 1 & & 5 & 1.4 & 2 & 3 & 2 & 0 & 0 & 3 & 4 & 1 & & & & & \\
\hline Walvis Ridge & 4 & & & & & & & & & & & & 1 & 18 & 2 & 0 & 0 & 14 & 60 & 5 & 100.0 & & & & \\
\hline & & & & & & & & & & & & & 1 & 4 & 1 & 0 & 0 & 6 & 12 & 0 & & & & & \\
\hline
\end{tabular}




\title{
APPENDIX
}

\section{" Dynamic uplift, recycling, and climate control on the petrology of passive-margin sand (Angola)"}

\author{
by Garzanti E., Dinis P., Vermeesch P., Andò S., Hahn A., Huvi J., Limonta M., \\ Padoan, M., Resentini, A., Rittner M., Vezzoli, G.
}

\begin{abstract}
APPENDIX A
Figure A1. Channel profiles of Angolan rivers draining into the Atlantic Ocean (same horizontal and vertical scale for all profiles). The alternation of subhorizontal and very steep tracts along the course of major rivers reflects the presence of stepped planation surfaces separated by escarpments, a characteristic feature of the dynamically uplifted landscapes of southwestern Angola. Fluvial network delineated in TecDEM (software shell implemented in MATLAB; Shahzad and Gloaguen, 2011) from a $30 \mathrm{~m}$ resolution digital elevation model provided by ASTER GDEM (http://www.gdem.aster.ersdac.or.jp). Channel concavity $\theta$ and steepness $k_{s}$ (referenced to a fixed concavity 0.45 to compare gradients in channels with different drainage areas; Korup and Schlunegger, 2009) are defined by a power-law relationship between the local channel slope $S$ and the contributing drainage area $A$ used as a proxy for discharge $\left(S=k_{S} A^{-\theta}\right.$; Flint 1974).
\end{abstract}

Table A1. Sample information. Location of the studied river, beach, shelfal and deep-sea sediment samples with year of sampling (see also the Google Earth file Angolamargin.kmz).

Table A2. Geomorphology and hydrology of Angolan river systems (data after National Directorate of Water, 2005). Sediment loads of Congo, Cuanza and Cunene rivers after Hay (1998), Holisticos (2012), and Bremner and Willis (1993), respectively.

Table A3. Sand petrography. GSZ= grain size. $Q=$ quartz $(\mathrm{Qp}=$ polycrystalline); $\mathrm{F}=$ feldspars $(\mathrm{KF}=\mathrm{K}$-feldspar; $\mathrm{P}=$ plagioclase; $\mathrm{Mic}=$ cross-hatched microcline $) ; \mathrm{L}=$ aphanitic lithic grains $(\mathrm{Lv}=$ volcanic and subvolcanic; Ls= sedimentary; $\mathrm{Lc}=$ carbonate; $\mathrm{Lh}=$ chert $\mathrm{Lp}=$ shale/siltstone; $\mathrm{Lm}=$ metamorphic; Lms= low-rank metasedimentary; Lmv= low-rank metavolcanic; Lmf= high-rank 
metapelite/metapsammite/metafelsite; $\mathrm{Lmb}=$ high-rank metabasite; Lu= ultramafic). $\mathrm{HM}=$ heavy minerals. Rock fragments: $\mathrm{V}=$ volcanic; $\mathrm{Vm}=$ intermediate and mafic volcanic; $\mathrm{M}=$ metamorphic; $\mathrm{Mb}=$ mafic metamorphic; n.d. = not determined. The Metamorphic Indices MI and MI* express the average metamorphic rank of rock fragments in each sample. MI varies from 0 (detritus shed by exclusively sedimentary and volcanic cover rocks) to 500 (very-high-rank detritus shed by exclusively high-grade basement rocks). MI* considers only metamorphic rock fragments, and thus varies from 100 (very-low-rank detritus shed by exclusively very low-grade metamorphic rocks) to 500 (Garzanti and Vezzoli, 2003).

Table A4. Heavy minerals. $\mathrm{GSZ}=$ grain size. $\mathrm{HM}=$ heavy minerals; $\mathrm{tHM}=$ transparent heavy minerals; HMC and tHMC = total and transparent-heavy-mineral concentration indices (Garzanti and Andò, 2007); RF= rock fragments; n.d. = not determined. The ZTR index (sum of zircon, tourmaline and rutile over total transparent heavy minerals) evaluates the "chemical durability" of the detrital assemblage (Hubert 1962). The HCI (Hornblende Colour Index) and MMI (Metasedimentary Minerals Index) vary from 0 in detritus from greenschist-facies to lowermost amphibolite-facies rocks yielding exclusively blue/green amphibole and chloritoid, to 100 in detritus from granulite-facies rocks yielding exclusively brown hornblende and sillimanite, and are used to estimate the average metamorphic grade of metaigneous and metasedimentary source rocks, respectively (Andò et al. 2014).

Table A5. Surface textures of heavy minerals in Angolan sediment samples. Determination of corrosion features on transparent heavy-mineral grains by three operators, following the classification of Andó et al. (2012). Q= quartz; F= feldspar; L= aphanitic lithic grains; n.d.= not determined.

Table A6. Geochemistry of Angolan sands (analyses made at ACME Laboratories, Vancouver). Following a lithium metaborate/tetraborate fusion and nitric acid digestion, major oxides and several minor elements were determined by inductively coupled plasma emission spectroscopy, and trace elements by ICP-MS. Discrepancies in replicate analyses are $\leq 1 \%$ for major elements and $\leq$ $5 \%$ for most trace elements (for further information on adopted procedures, geostandards used, and precision for various elements of group 4A-4B and code LF200 see http://acmelab.com). A separate split was digested in aqua regia and analyzed by ICP-MS for $\mathrm{Mo}, \mathrm{Ni}, \mathrm{Cu}, \mathrm{Ag}, \mathrm{Au}, \mathrm{Zn}, \mathrm{Cd}, \mathrm{Hg}, \mathrm{Tl}$, $\mathrm{Pb}, \mathrm{As}, \mathrm{Sb}, \mathrm{Bi}$, and $\mathrm{Se}$. Elements analysed by aqua regia digestion (a.r.d.) are commonly underestimated because of only partial leaching of refractory minerals. Chemical weathering indices are defined in Nesbitt and Young (1982; CIA), Harnois (1988; CIW), Fedo et al. (1995; PIA), 
Parker (1970; WIP), and Garzanti et al. (2014; CIX). In order to avoid bias caused by hydraulic concentration of heavy minerals hosting Ti, REE and Th, $\alpha^{\mathrm{Al}}$ values were normalized to non-mobile $\mathrm{Al}$ (Garzanti et al., 2014). The Eu anomaly is the measured chondrite-normalized Eu value over the value that $\mathrm{Eu}$ would have in a linear extrapolation between chondrite-normalized values of Sm and Gd. The Ce anomaly, indicative of redox state, is the measured PAAS-normalized Ce value over the value that Ce would have in a linear extrapolation between PAAS-normalized values of La and Pr. MREE is the average of $\mathrm{Eu}, \mathrm{Gd}, \mathrm{Tb}$ and Dy normalized to PAAS, MREE* the average of LREE (La, Ce, Pr, Nd) and HREE (Er, Tm, Yb, Lu) values (Haley et al., 2004). The chondrite-normalized $\mathrm{La}_{\mathrm{N}} / \mathrm{Yb}_{\mathrm{N}}, \mathrm{La}_{\mathrm{N}} / \mathrm{Sm}_{\mathrm{N}}, \mathrm{Gd}_{\mathrm{N}} / \mathrm{Ho}_{\mathrm{N}}$, and $\mathrm{Ho}_{\mathrm{N}} / \mathrm{Yb}_{\mathrm{N}}$ ratios are also given. $\mathrm{GSZ}=$ grain size; D.L. = detection limit; n.d.= not determined.

\section{APPENDIX B}

\section{U-Pb detrital zircon geochronology of modern sands from northern Namibia and southern} Angola (analyses made at the London Geochronology Centre, University College London). We used ${ }^{206} \mathrm{~Pb} /{ }^{238} \mathrm{U}$ and ${ }^{207} \mathrm{~Pb} /{ }^{206} \mathrm{~Pb}$ ages for zircons younger and older than $1100 \mathrm{Ma}$, respectively; grains with $>10 \%$ age discordance were discarded. No common $\mathrm{Pb}$ correction was applied. Grains with $+5 /-15 \%$ age discordance were discarded.

\section{CITED REFERENCES}

Andò, S., Garzanti, E., Padoan, M., Limonta, M., 2012. Corrosion of heavy minerals during weathering and diagenesis: a catalog for optical analysis. Sedimentary Geology, 280, 165-178.

Andó, S., Morton, A., Garzanti, E., 2014. Metamorphic grade of source rocks revealed by chemical fingerprints of detrital amphibole and garnet. In: Scott, R., Smyth. H., Morton, A., Richardson, N. (Eds.), Sediment provenance studies in hydrocarbon exploration and production. Geological Society London, Special Publications 386, pp. 351-371.

Bremner, J.M.,Willis, J.P., 1993. Mineralogy and geochemistry of the clay fraction of sediments from the Namibian continental margin and the adjacent hinterland. Marine Geology, 115, 85-116.

Fedo, C.M., Nesbitt, H.W., Young, G.M., 1995. Unraveling the effects of potassium metasomatism in sedimentary rocks and paleosols, with implications for paleoweathering conditions and provenance. Geology, 23, 921-924.

Flint, J.J., 1974. Stream gradient as a function of order, magnitude, and discharge. Water Resources Research, 10, 969-973.

Garzanti, E., Andò, S., 2007. Heavy-mineral concentration in modern sands: implications for provenance interpretation. In: Mange, M.A., Wright, D.T. (Eds.), Heavy Minerals in Use. Elsevier, Amsterdam, Developments in Sedimentology Series 58, pp.517-545. 
Garzanti, E., Vezzoli, G., 2003. A classification of metamorphic grains in sands based on their composition and grade. Journal of Sedimentary Research, 73, 830-837.

Garzanti, E., Vermeesch, P., Padoan, M., Resentini, A., Vezzoli, G., Andò, S., 2014. Provenance of passivemargin sand (southern Africa). The Journal of Geology, 122, 17-42.

Haley, B.A., Klinkhammer, G.P., McManus, J., 2004. Rare earth elements in pore waters of marine sediments. Geochimica Cosmochimica Acta, 68,1265-1279.

Harnois, L., 1988. The CIW index: a new chemical index of weathering. Sedimentary Geology, 55, 319-322.

Hay, W.W., 1998. Detrital sediment fluxes from continents to oceans. Chemical Geology, 145, 287-323.

Holisticos, 2012. Environmental impact study for the rehabilitation and expansion of the Cambambe hydroelectric power plant. https://www.miga.org/documents/Angola_Cambambe_HPP_EIS.pdf

Korup, O., Schlunegger, F., 2009. Rock-type control on erosion-induced uplift, eastern Swiss alps. Earth and Planetary Science Letters, 278, 278-285.

Hubert, J.F., 1962. A zircon-tourmaline-rutile maturity index and the interdependence of the composition of heavy minerals assemblages with the gross composition and texture of sandstones. Journal of Sedimentary Petrology 32:440-450.

National Directorate of Water, 2005. A rapid water resources and water use assessment for Angola, Final Report. Ministry of Energy and Water Affairs, Republic of Angola, National Water Sector Management Project, Activity C, 307 p.

Nesbitt, H.W., Young, G.M., 1982. Early Proterozoic climates and plate motions inferred from major element chemistry of lutites. Nature, 299, 715-717.

Parker, A., 1970. An index of weathering for silicate rocks. Geological Magazine, 107, 501-504.

Shahzad, F., Gloaguen, R., 2011. TecDEM: a MATLAB based toolbox for tectonic geomorphology, part 1: drainage network pre-processing and stream profile analysis. Computers \& Geosciences, 37, 250-260. 
Click here to download high resolution image

\begin{tabular}{|cccccc|}
\hline River & $\begin{array}{c}\text { Area } \\
\mathrm{km}^{2}\end{array}$ & $\begin{array}{c}\text { Length } \\
\mathrm{km}\end{array}$ & $\begin{array}{c}\text { Elevation mean } \\
\mathrm{m}\end{array}$ & $\mathrm{k}_{\mathrm{i}}$ & $\theta$ \\
Mebridege & 19071 & 290 & 589 & 121 & 0.13 \\
Dande & 11446 & 295 & 621 & 141 & 0.29 \\
Longa & 23031 & 310 & 888 & 106 & 0.09 \\
Queve & 22815 & 300 & 1360 & 114 & 0.11 \\
Catumbela & 16533 & 240 & 1321 & 107 & -0.06 \\
Coporolo & 15239 & 220 & 908 & 94 & 0.21 \\
Bero & 10476 & 210 & 718 & 121 & 0.31 \\
Cunene & 113835 & 1050 & 1286 & 66 & -0.02 \\
\hline
\end{tabular}
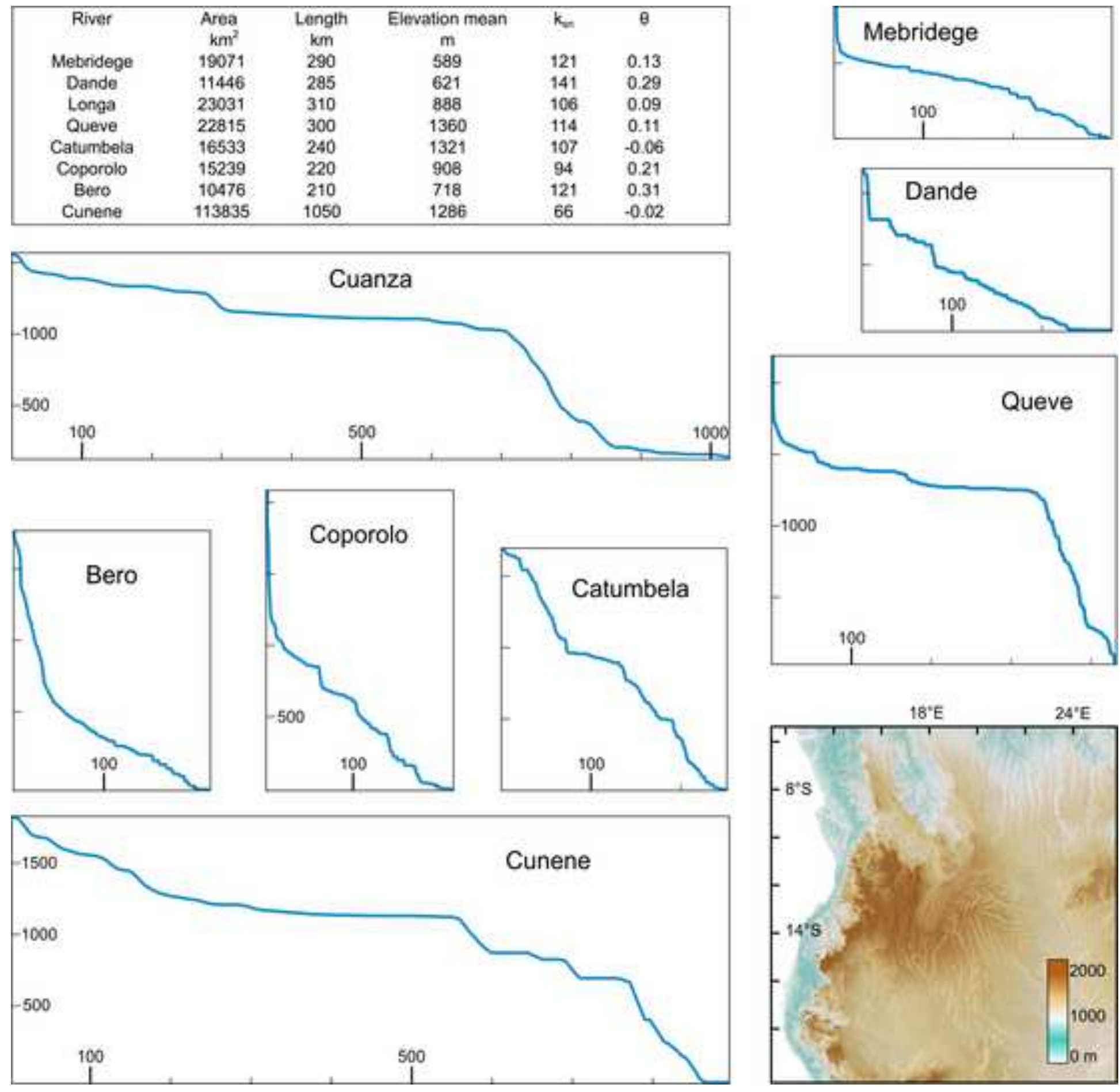


\begin{tabular}{|c|c|c|c|c|c|c|c|c|}
\hline Sample & River / Desert & Site & Facies & Country & Collected by & Year & Latitude & Longitude \\
\hline S4053 & Loussoni & St. Paul & river sand & Congo & M.Orlando & 2009 & S 0428 & E 1212 \\
\hline S0162 & & Pointe Noire & beach sand & Congo & D. Dell'Era & 1997 & S 0448 & E 1150 \\
\hline S0161 & Loémé & Djeno & river sand & Congo & D. Dell'Era & 1997 & S 0454 & E 1156 \\
\hline S3533 & Congo & Brazzaville & river sand & Congo & F.Bolognesi & 2005 & S 417 & E 1517 \\
\hline S5114 & Congo & Kinshasa & river sand & Congo & P.Vermesch & 2016 & S 041932 & E 151342 \\
\hline S5115 & Congo & Boma & river sand & Congo & P.Vermesch & 2016 & S 055158 & E 130014 \\
\hline S4899 & Congo & Soyo & estuary sand & Angola & E.Garzanti & 2015 & S 060752 & E 122225 \\
\hline S4898 & Congo & Soyo estuary & estuary sand & Angola & E.Garzanti & 2015 & S 060709 & E 122132 \\
\hline S4901 & & Quimtomba & beach sand & Angola & E.Garzanti & 2015 & S 061500 & E 122046 \\
\hline S4902 & & Quifuma & beach sand & Angola & E.Garzanti & 2015 & S 062330 & E 122537 \\
\hline S4904 & Luculu & Quivanda & estuary sand & Angola & E.Garzanti & 2015 & S 064115 & E 123452 \\
\hline S4903 & & Quivanda & beach sand & Angola & E.Garzanti & 2015 & S 064117 & E 123449 \\
\hline S4905 & & Mbua-Moyo & beach sand & Angola & E.Garzanti & 2015 & S 065142 & E 124432 \\
\hline S4897 & Mebridege & Cassa de Telha & river sand & Angola & E.Garzanti & 2015 & S 070824 & E 125858 \\
\hline S4906 & & N'Zeto & beach sand & Angola & E.Garzanti & 2015 & S 071342 & E 125114 \\
\hline S4907 & & Pidi mouth & beach sand & Angola & E.Garzanti & 2015 & S 071802 & E 125303 \\
\hline S4908 & & Musserra & beach sand & Angola & E.Garzanti & 2015 & S 073451 & E 130016 \\
\hline S4895 & Sembo & Musserra & river sand & Angola & E.Garzanti & 2015 & S 073935 & E 131126 \\
\hline S4894 & Loge & Porta Freitas Morna & river sand & Angola & E.Garzanti & 2015 & S 074356 & E 131956 \\
\hline S4909 & & Ambriz & beach sand & Angola & E.Garzanti & 2015 & S 075058 & E 130617 \\
\hline S4893 & Onzo & Tabi & river sand & Angola & E.Garzanti & 2015 & S 080947 & E 132531 \\
\hline S4892 & Lifune & Conde Loca & river sand & Angola & E.Garzanti & 2015 & S 082318 & E 132816 \\
\hline$S 4910$ & & Barra do Dande & beach sand & Angola & E.Garzanti & 2015 & S 082804 & E 132258 \\
\hline S4891 & Dande & Caxito & river sand & Angola & E.Garzanti & 2015 & S 083623 & E 133333 \\
\hline S4911 & Bengo & Quifangondo & estuary sand & Angola & E.Garzanti & 2015 & S 084348 & E 132617 \\
\hline S4912 & & Cacuaco & beach sand & Angola & E.Garzanti & 2015 & S 084624 & E 132215 \\
\hline S4652 & & Ilha de Luanda & beach sand & Angola & R.Giardini & 2013 & S 847 & E 13 14E \\
\hline S3764 & & Mussulo & beach sand & Angola & M.Orlando & 2008 & S 859 & E 1302 \\
\hline S4913 & & Palmeirinhas & beach sand & Angola & E.Garzanti & 2015 & S 090716 & E 130057 \\
\hline S4914 & & Barra do Cuanza & estuary sand & Angola & E.Garzanti & 2015 & S 092024 & E 130902 \\
\hline S4915 & Cuanza & Barra do Cuanza & river sand & Angola & E.Garzanti & 2015 & S 091922 & E 130945 \\
\hline S3765 & & Cabo Ledo & beach sand & Angola & M.Orlando & 2008 & S 940 & E 1313 \\
\hline S4916 & & Sao Braz & beach sand & Angola & E.Garzanti & 2015 & S 095827 & E 131931 \\
\hline S4917 & Longa & Calamba & river sand & Angola & E.Garzanti & 2015 & S 101150 & E 133116 \\
\hline S4918 & & Porto Amboim & beach sand & Angola & E.Garzanti & 2015 & S 104236 & E 134630 \\
\hline S4919 & & Sumbe & beach sand & Angola & E.Garzanti & 2015 & S 110947 & E 135019 \\
\hline S4920 & & Quicombo & beach sand & Angola & P.Dinis & 2015 & S 111905 & E 134855 \\
\hline S4921 & & Candunga & beach sand & Angola & P.Dinis & 2015 & S 114424 & E 134739 \\
\hline S4922 & Queve & Cachoeira & river sand & Angola & E.Garzanti & 2015 & S 105919 & E 140545 \\
\hline S4923 & & Carimba & beach sand & Angola & E.Garzanti & 2015 & S 110435 & E 135120 \\
\hline S4924 & Cambongo & Sumbe & river sand & Angola & E.Garzanti & 2015 & S 111156 & E 135047 \\
\hline S4925 & Quicombo & Quicombo & river sand & Angola & E.Garzanti & 2015 & S 111918 & E 135025 \\
\hline S4926 & Tapado & Chitonde & river sand & Angola & E.Garzanti & 2015 & S 114838 & E 135647 \\
\hline S4927 & Balombo & Canjala & river sand & Angola & E.Garzanti & 2015 & S 115945 & E 135945 \\
\hline S4928 & & Egito Praia & beach sand & Angola & E.Garzanti & 2015 & S 115737 & E 134542 \\
\hline S4929 & Culango & Culango & river sand & Angola & E.Garzanti & 2015 & S 121804 & E 134954 \\
\hline$S 4930$ & & Praia Sousa & beach sand & Angola & P.Dinis & 2015 & S 113636 & E 134706 \\
\hline S4934 & & Lobito spit & beach sand & Angola & E.Garzanti & 2015 & S 121858 & E 133452 \\
\hline S4865 & & Lobito spit & beach sand & Angola & P.Dinis & 2014 & S 121914 & E 133445 \\
\hline S4863 & & Lobito spit & beach sand & Angola & P.Dinis & 2014 & S 122019 & E 133304 \\
\hline S4864 & & Lobito spit & beach sand & Angola & P.Dinis & 2014 & S 122022 & E 133306 \\
\hline S4862 & & Catumbela N & beach sand & Angola & P.Dinis & 2014 & S 122451 & E 132942 \\
\hline PB.AC & & Catumbela mouth & beach sand & Angola & P.Dinis & 2014 & S 122614 & E 132858 \\
\hline S4861 & & Catumbela mouth & beach sand & Angola & P.Dinis & 2014 & S 122702 & E 132833 \\
\hline S4655 & Catumbela & Praia Bebe & beach placer & Angola & A. Pereira & 2013 & S 122700 & E 132830 \\
\hline S5118 & Cubal da Hanha & Vista Alegre & river sand & Angola & J.Huvi & 2017 & S 124944 & E 135914 \\
\hline $\mathrm{CAV}$ & Catumbela & Fazenda Santo Antonio & river sand & Angola & P.Dinis & 2014 & S 123017 & E 134654 \\
\hline S5116 & Calumbolo & Supua & river sand & Angola & J.Huvi & 2017 & S 122700 & E 134606 \\
\hline S5117 & Capilongo & Capilongo & river sand & Angola & J.Huvi & 2017 & S 122750 & E 133622 \\
\hline S4933 & Catumbela & Catumbela & river sand & Angola & E.Garzanti & 2015 & S 122627 & E 133303 \\
\hline S4860 & Catumbela & Catumbela & river sand & Angola & P.Dinis & 2014 & S 122700 & E 133432 \\
\hline S4859 & & Catumbela airport & beach sand & Angola & P.Dinis & 2014 & S 123017 & E 132856 \\
\hline S4932 & Cavaco & Benguela & river sand & Angola & E.Garzanti & 2015 & S 123400 & E 132504 \\
\hline$S 4931$ & & Benguela & beach sand & Angola & E.Garzanti & 2015 & S 123445 & E 132340 \\
\hline S4935 & & Baia Farta & beach sand & Angola & E.Garzanti & 2015 & S 123551 & E 131215 \\
\hline S4858 & & Baia Farta & beach sand & Angola & P.Dinis & 2014 & S 123657 & E 131126 \\
\hline S4857 & & Canucua & beach sand & Angola & P.Dinis & 2014 & S 124753 & E 125914 \\
\hline S4856 & & Saco NE & beach sand & Angola & P.Dinis & 2014 & S 125125 & E 125703 \\
\hline
\end{tabular}




\begin{tabular}{|c|c|c|c|c|c|c|c|c|}
\hline S4855 & & Saco $N$ & beach sand & Angola & P.Dinis & 2014 & S 125142 & E 125618 \\
\hline S4854 & & Saco SE & beach sand & Angola & P.Dinis & 2014 & S 125230 & E 125716 \\
\hline S4853 & & Saco S & beach sand & Angola & P.Dinis & 2014 & S 125246 & E 125639 \\
\hline S4852 & Coporolo & Santa Tereza & beach sand & Angola & P.Dinis & 2014 & S 125401 & E 130520 \\
\hline S4936 & Coporolo & Dombe Grande & river sand & Angola & E.Garzanti & 2015 & S 125501 & E 130620 \\
\hline S4937 & & Cuio & beach sand & Angola & E.Garzanti & 2015 & S 125858 & E 125843 \\
\hline S4938 & & Equimina & beach sand & Angola & E.Garzanti & 2015 & S 131149 & E 124654 \\
\hline S4939 & & Baia Binga & beach sand & Angola & E.Garzanti & 2015 & S 132019 & E 123906 \\
\hline S4940 & Cangala & Santa Maria & river sand & Angola & E.Garzanti & 2015 & S 133333 & E 123828 \\
\hline S4941 & & Lucira & beach sand & Angola & E.Garzanti & 2015 & S 135158 & E 123114 \\
\hline S4942 & Carujamba & Lucira & river sand & Angola & E.Garzanti & 2015 & S 135919 & E 123101 \\
\hline S4943 & (low outer berm) & Inamangando & beach sand & Angola & E.Garzanti & 2015 & S 140233 & E 122309 \\
\hline S4944 & (high inner berm) & Inamangando & beach sand & Angola & E.Garzanti & 2015 & S 140234 & E 122310 \\
\hline S4945 & Inamangando & Inamangando & river sand & Angola & E.Garzanti & 2015 & S 140304 & E 122538 \\
\hline S4946 & & Baia das Salinas & beach sand & Angola & E.Garzanti & 2015 & S 141118 & E 122038 \\
\hline S4947 & Bentiaba & Bentiaba & river sand & Angola & E.Garzanti & 2015 & S 141605 & E 122246 \\
\hline S4948 & & Bentiaba & beach sand & Angola & E.Garzanti & 2015 & S 141723 & E 122211 \\
\hline P4948 & & Bentiaba & beach placer & Angola & E.Garzanti & 2015 & S 141723 & E 122211 \\
\hline S4949 & & Chapeu Armado & beach sand & Angola & E.Garzanti & 2015 & S 142655 & E 122038 \\
\hline S4950 & & Mariquita & beach sand & Angola & E.Garzanti & 2015 & S 144541 & E 121704 \\
\hline S4951 & Giraul & Giraul & river sand & Angola & E.Garzanti & 2015 & S 150430 & E 120918 \\
\hline S4952 & Bero & Namibe & river sand & Angola & E.Garzanti & 2015 & S 150954 & E 121005 \\
\hline S4953 & & Namibe & beach sand & Angola & E.Garzanti & 2015 & S 151132 & E 120850 \\
\hline \multicolumn{9}{|c|}{ Moçamedes Desert } \\
\hline S4954 & & Subida Grande & beach sand & Angola & E.Garzanti & 2015 & S 152521 & E 120154 \\
\hline S4802 & (fossil dune) & Nonguai & fossil dune & Angola & P.Dinis & 2014 & S 154557 & E 120440 \\
\hline S4955 & Curoca & Curoca mouth & river sand & Angola & E.Garzanti & 2015 & S 154353 & E 115524 \\
\hline S4956 & & Curoca mouth & beach sand & Angola & E.Garzanti & 2015 & S 154356 & E 115438 \\
\hline S4804 & & Tombua & beach sand & Angola & P.Dinis & 2014 & S 154754 & E 115118 \\
\hline S4805 & (outer spit) & Tombua & beach sand & Angola & P.Dinis & 2014 & S 154720 & E 114908 \\
\hline S4774 & & Tombua & eolian dune & Angola & E.Baptista & 2014 & S 154756 & E 115154 \\
\hline S4957 & & Vanesa & beach sand & Angola & E.Garzanti & 2015 & S 155709 & E 114606 \\
\hline S4961 & & Cova dos Medos & eolian dune & Angola & E.Garzanti & 2015 & S 160124 & E 114847 \\
\hline S4958 & & Vanesinha & beach sand & Angola & E.Garzanti & 2015 & S 160925 & E 114736 \\
\hline S4959 & & Praia do Navio & beach sand & Angola & E.Garzanti & 2015 & $S 161623$ & E 114835 \\
\hline S4960 & & Praia do Navio & eolian dune & Angola & P.Vermeesch & 2015 & S 161625 & E 114844 \\
\hline S5058 & & Riscos & beach sand & Angola & A.Sampaio & 2016 & S 163000 & E 114921 \\
\hline S5059 & & Riscos & eolian dune & Angola & A.Sampaio & 2016 & S 163000 & E 114921 \\
\hline S5057 & & Saco dos Tigres & beach sand & Angola & A.Sampaio & 2016 & S 164827 & E 114813 \\
\hline S5055 & & Praia dos Esponjas & beach sand & Angola & A.Sampaio & 2016 & S 1705 & E 114440 \\
\hline S5056 & & Praia dos Esponjas & eolian dune & Angola & A.Sampaio & 2016 & S 1705 & E 114440 \\
\hline S5054 & & Foz do Cunene & eolian dune & Angola & A.Sampaio & 2016 & S 171524 & E 114518 \\
\hline S5053 & & Foz do Cunene & beach sand & Angola & A.Sampaio & 2016 & S 171524 & E 114518 \\
\hline \multicolumn{9}{|c|}{ Cunene catchment } \\
\hline S5050 & Caculuvar & Techango & river sand & Angola & A.Trindade & 2016 & S 163815 & E 145416 \\
\hline S5049 & Mucope & Techiulo & river sand & Angola & A.Trindade & 2016 & S 163146 & E 145222 \\
\hline S3931 & Cunene & Ruacana & river sand & Namibia & L.Ciceri & 2008 & S 172430 & E 1413 \\
\hline S3934 & Omuhongo & Oryeheke & river sand & Namibia & L.Ciceri & 2008 & S 165920 & E 132210 \\
\hline S4775 & Cunene & Epupa Falls & river sand & Namibia & F.Vermeesch & 2014 & S 1700 & E 1315 \\
\hline S5052 & Cunene & Foz do Cunene & estuary sand & Angola & A.Sampaio & 2016 & S 171524 & E 114518 \\
\hline \multicolumn{3}{|c|}{ OFFSHORE CORE TOP SAMPLES } & Depth (m) & & Corer & & & \\
\hline 1004 & Meteor M6/6 & GeoB1004-3 & -31 & Congo mouth & Giant box corer & 1988 & S 060558 & E 120739 \\
\hline 1001 & Meteor M6/6 & GeoB1001-1 & -45 & Congo mouth & Giant box corer & 1988 & S 055158 & E 115820 \\
\hline 1011 & Meteor M6/6 & GeoB1011_2 & -73 & Tabado mouth & Giant box corer & 1988 & S 114814 & E 133941 \\
\hline $1012 / 1$ & Meteor M6/6 & GeoB1012 1 & -99 & Tabado mouth & Giant box corer & 1988 & S 114833 & E 133527 \\
\hline $1012 / 2$ & Meteor M6/6 & GeoB1012_2 & -99 & Tabado mouth & Giant box corer & 1988 & S 114833 & E 133527 \\
\hline 1013 & Meteor M6/6 & GeoB1013_2 & -250 & Tabado mouth & Giant box corer & 1988 & S 114755 & E 132647 \\
\hline $2 / 25-7$ & ODP Leg 175 & $1078 \mathrm{~A}$ & -438 & Balombo mouth & Piston corer & 1997 & S 115513 & E 132408 \\
\hline $3 / 115-17$ & ODP Leg 175 & $1078 \mathrm{~A}$ & -438 & Balombo mouth & Piston corer & 1997 & S 115513 & E 132408 \\
\hline $1 / 2105-106$ & DSDP Leg 40 & 365 & -3040 & Cuanza volcanic ridge & Rotary core barrel & 1975 & S 113906 & E 115343 \\
\hline $1 / 665-67$ & DSDP Leg 40 & 365 & -3040 & Cuanza volcanic ridge & Rotary core barrel & 1975 & S 113906 & E 115343 \\
\hline 4918 & Meteor M41/1 & GeoB4918_5 & -1339 & Coporolo mouth & Gravity corer & 1998 & S 125024 & E 124148 \\
\hline $1 / 189-91$ & ODP Leg 175 & $1080 \mathrm{~A}$ & -2766 & Baia dos Tigres & Piston corer & 1997 & S 163335 & E 104912 \\
\hline $2 / 431-33$ & ODP Leg 175 & $1080 \mathrm{~A}$ & -2766 & Baia dos Tigres & Piston corer & 1997 & S 163335 & E 104912 \\
\hline $1 / 665-67$ & ODP Leg 175 & $1080 \mathrm{~B}$ & -2768 & Baia dos Tigres & Piston corer & 1997 & $S 163336$ & E 104912 \\
\hline 1019 & Meteor M6/6 & GeoB1019-3 & -75 & Cunene mouth & Giant box corer & 1988 & S 171029 & E 113850 \\
\hline 1020 & Meteor M6/6 & GeoB1020-1 & -110 & Cunene mouth & Giant box corer & 1988 & S 171007 & E 113253 \\
\hline 1021 & Meteor M6/6 & GeoB1021-3 & -173 & Cunene mouth & Giant box corer & 1988 & S 171034 & E 112400 \\
\hline 1022 & Meteor M6/6 & GeoB1022-2 & -551 & Cunene mouth & Giant box corer & 1988 & S 171024 & E 111753 \\
\hline 1704 & Meteor 20/2 & GeoB1704-1 & -399 & Walvis Ridge & Giant box corer & 1992 & S 192424 & E 113642 \\
\hline 1705 & Meteor 20/2 & GeoB1705-1 & -642 & Walvis Ridge & Gravity corer & 1992 & S 193018 & E 112354 \\
\hline
\end{tabular}


Appendix Table A2

Click here to download Table: Table A2 Angola Rivers.pdf

\section{Table A2}

\begin{tabular}{|c|c|c|c|c|c|c|c|c|c|c|c|c|c|}
\hline \multirow{3}{*}{ River } & \multirow[b]{3}{*}{$\begin{array}{l}\text { Area } \\
\mathrm{km}^{2}\end{array}$} & \multirow[b]{3}{*}{$\begin{array}{l}\text { Length } \\
\text { km }\end{array}$} & \multirow[b]{3}{*}{$\begin{array}{l}\text { Perimeter } \\
\mathrm{km}\end{array}$} & \multirow{2}{*}{\multicolumn{2}{|c|}{ Elevation }} & \multirow{2}{*}{\multicolumn{4}{|c|}{ Annual water discharge }} & \multirow[b]{3}{*}{$\begin{array}{c}\text { Precipitation } \\
\qquad \mathrm{mm} / \mathrm{a}\end{array}$} & \multirow[b]{3}{*}{$\begin{array}{l}\text { Sdm.load } \\
\text { ton/a }\end{array}$} & \multirow[b]{3}{*}{$\begin{array}{l}\text { Sdm.yield } \\
\text { ton/km2 a }\end{array}$} & \multirow[b]{3}{*}{$\begin{array}{c}\text { Erosion } \\
\mathrm{mm} / \mathrm{a}\end{array}$} \\
\hline & & & & & & & & & & & & & \\
\hline & & & & $\begin{array}{c}\text { mean } \\
m \text { a.s.l. }\end{array}$ & $\begin{array}{c}\max \\
m \text { a.s.l. }\end{array}$ & $\begin{array}{l}\text { mean } \\
\mathrm{m}^{3} / \mathrm{s}\end{array}$ & $\begin{array}{c}\text { mean spec. } \\
\mathrm{l} / \mathrm{s} \mathrm{km}^{2}\end{array}$ & $\begin{array}{c}\max \text { spec. } \\
1 / \mathrm{sm}^{2}\end{array}$ & $\begin{array}{c}\min \text { spec. } \\
q\end{array}$ & & & & \\
\hline Congo & 4014500 & 4700 & 11895 & 955 & 1548 & 41000 & 8.7 & 11.6 & 5.5 & 1375 & 60000000 & 15 & 0.006 \\
\hline Luculu & 1449 & 95 & 185 & 151 & 315 & 8 & 5.6 & 6.0 & 4.7 & 836 & & & \\
\hline Mebridege & 19071 & 290 & 890 & 589 & 1295 & 124 & 6.5 & 11.4 & 3.5 & 974 & & & \\
\hline Sembo & 2093 & 125 & 250 & 284 & 734 & 7 & 3.3 & 4.4 & 2.6 & 550 & & & \\
\hline Loge & 12819 & 230 & 581 & 531 & 1281 & 53 & 4.1 & 10.4 & 1.9 & 612 & & & \\
\hline Onzo & 2942 & 130 & 324 & 359 & 913 & 7 & 2.4 & 2.8 & 2.0 & 415 & & & \\
\hline Lifune & 3019 & 150 & 334 & 376 & 1133 & 9 & 2.9 & 4.5 & 2.4 & 513 & & & \\
\hline Dande & 11446 & 285 & 649 & 621 & 1474 & 59 & 5.2 & 10.0 & 2.4 & 832 & & & \\
\hline Bengo & 11089 & 300 & 663 & 483 & 1530 & 44 & 3.9 & 7.4 & 1.5 & 883 & & & \\
\hline Cuanza & 150446 & 965 & 2702 & 1200 & 1964 & 1064 & 7.1 & 14.2 & 1.6 & 1188 & 618500 & 4 & 0.0016 \\
\hline Longa & 23031 & 310 & 791 & 888 & 2099 & 138 & 6.0 & 9.1 & 3.3 & 991 & & & \\
\hline Queve & 22815 & 300 & 899 & 1360 & 2575 & 213 & 9.4 & 16.3 & 2.6 & 1131 & & & \\
\hline Cambongo & 2309 & 310 & 286 & 867 & 2260 & 14 & 5.9 & 10.9 & 2.6 & 763 & & & \\
\hline Quicombo & 5512 & 50 & 434 & 1081 & 2545 & 40 & 7.2 & 15.6 & 0.9 & 965 & & & \\
\hline Tapado & 1617 & 40 & 190 & 582 & 1583 & 7 & 4.1 & 7.4 & 2.3 & 745 & & & \\
\hline Balombo & 4414 & 200 & 451 & 1186 & 2609 & 42 & 9.6 & 18.4 & 2.8 & 1100 & & & \\
\hline Culango & 2881 & 120 & 266 & 949 & 2142 & 13 & 4.3 & 8.4 & 2.3 & 883 & & & \\
\hline Catumbela & 16533 & 240 & 748 & 1321 & 2570 & 149 & 9.0 & 17.3 & 1.8 & 1182 & & & \\
\hline Cavaco & 4398 & 120 & 313 & 738 & 1570 & 19 & 4.4 & 6.8 & 1.6 & 751 & & & \\
\hline Coporolo & 15239 & 220 & 667 & 908 & 2406 & 70 & 4.6 & 9.2 & 1.1 & 846 & & & \\
\hline Cangala & 363 & 60 & 115 & 547 & 827 & 0.3 & 0.8 & 1.1 & 0.4 & 312 & & & \\
\hline Carujamba & 2931 & 160 & 305 & 664 & 1230 & 5 & 1.8 & 3.8 & 0.2 & 560 & & & \\
\hline Inamangando & 1859 & 145 & 263 & 623 & 1477 & 2 & 1.1 & 3.0 & 0.1 & 479 & & & \\
\hline Bentiaba & 6935 & 210 & 472 & 873 & 2325 & 12 & 1.8 & 3.7 & 0.2 & 648 & & & \\
\hline Giraul & 4709 & 190 & 393 & 615 & 2322 & 4 & 0.8 & 2.5 & 0.1 & 409 & & & \\
\hline Bero & 10476 & 210 & 588 & 718 & 2094 & 5 & 0.5 & 1.5 & 0.1 & 364 & & & \\
\hline Curoca & 19338 & 324 & 849 & 762 & 1864 & 4 & 0.2 & 0.9 & 0.0 & 238 & & & \\
\hline Cunene & 113835 & 1050 & 2390 & 1286 & 2484 & 290 & 2.5 & 13.7 & 0.0 & 704 & 8700000 & 76 & 0.029 \\
\hline
\end{tabular}


Appendix Table A3

Click héplare to download Table: Table A3 Angola PT.pdf

$\begin{array}{llllll}\text { RIVERS \& BEACHES IN THE CONGO } & & & & \\ \text { Loussoni } & \text { St. Paul } & \text { S4053 } & \text { G.Vezzoli } & 325 & 99 \\ & \text { Pointe Noire } & \text { S0162 } & \text { G.Vezzoli } & 510 & 99 \\ \text { Loémé } & \text { Djeno } & \text { S0161 } & \text { G.Vezzoli } & 220 & 99 \\ \text { Congo } & \text { Brazzaville } & \text { S3533 } & \text { G.Vezzoli } & 240 & 97 \\ \text { Congo } & \text { Kinshasa } & \text { S5114 } & \text { G.Vezzoli } & 160 & 98 \\ \text { Congo } & \text { Boma } & \text { S5115 } & \text { G.Vezzoli } & 125 & 97 \\ \text { Congo } & \text { Soyo } & \text { S4899 } & \text { G.Vezzoli } & 175 & 98\end{array}$

$\begin{array}{llllll}\text { Congo } & \text { Soyo } & \text { S4899 } & \text { G.Vezzoli } & 175 & 98 \\ \text { Congo } & \text { Soyo estuary } & \text { S4898 } & \text { A.Resentini } & 180 & 98\end{array}$

BEACHES \& SHELF IN NORTHERN ANGOLA

1004-3 G.Vezzoli $200 \quad 82$

\begin{tabular}{llccc} 
Quimtomba & S4901 & G.Vezzoli & 630 & 97 \\
Quifuma & S4902 & A.Resentini & 345 & 95 \\
Quivanda & S4903 & A.Resentini & 350 & 88 \\
Mbua-Moyo & S4905 & A.Resentini & 380 & 90 \\
Pidi mouth & S4907 & A.Resentini & 245 & 77 \\
Musserra & S4908 & G. Vezzzoli & 325 & 72 \\
Ambriz & S4909 & A.Resentini & 330 & 82 \\
Barra do Dande & S4910 & G.Vezzoli & 460 & 82 \\
\hline Cand & S4912 & A.Resentini & 120 & 92
\end{tabular}

RIVERS IN NORTHERN ANGOLA

$\begin{array}{ll}\text { Luculu } & \text { Quivanda } \\ \text { Mebridege } & \text { Cassa de Telha } \\ \text { Sembo } & \text { Musserra } \\ \text { Loge } & \text { Porta Freitas Morna } \\ \text { Onzo } & \text { Tabi } \\ \text { Lifune } & \text { Conde Loca } \\ \text { Dande } & \text { Caxito } \\ \text { Bengo } & \text { Quifangondo } \\ \text { CUANZA \& CUANZA LITTORAL CELL }\end{array}$

S4904 A.Resentini $370 \quad 80$

\begin{tabular}{llll} 
S4897 & A.Resentini & 345 & 93 \\
S4895 & A.Resentini & 750 & 77 \\
\hline
\end{tabular}

S4894 A.Resentini $305 \quad 76$

$\begin{array}{llll}\text { S4893 } & \text { A.Resentini } & 480 & 81 \\ \text { S4892 } & \text { A.Resentini } & 345 & 87\end{array}$

CUANZA \& CUANZA LITTORAL CELL

Ilha de Luand
Mussulo

Palmeirinhas

$\begin{array}{llll}\text { S4891 } & \text { A.Resentini } & 150 & 80 \\ \text { A.Resentini } & 135 & 82\end{array}$

Cuanzar Barra do Cuanza

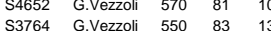

BEACHES \& SHELF IN CENTRAL
Cabo Ledo

Sao Braz
Porto Amboim

Carimba

Praia Sousa
Egito Praia

$-73 \mathrm{~m}$ shelf offshore of Tapado mouth

RIVERS IN CENTRAL ANGOLA

$\begin{array}{ll}\text { Longa } & \text { Calamba } \\ \text { Queve } & \text { Cachoeira }\end{array}$

$\begin{array}{ll}\text { Cambongo } & \text { Sumbe } \\ \text { Quicombo } & \text { Quicombo } \\ \text { Tapado } & \text { Chitonde }\end{array}$

$\begin{array}{ll}\text { Tapado } & \text { Chitonde } \\ \text { Balombo } & \text { Canjala }\end{array}$

Culango Culango
COPOROLO, CATUMBELA \& LITTORAL CEUIS

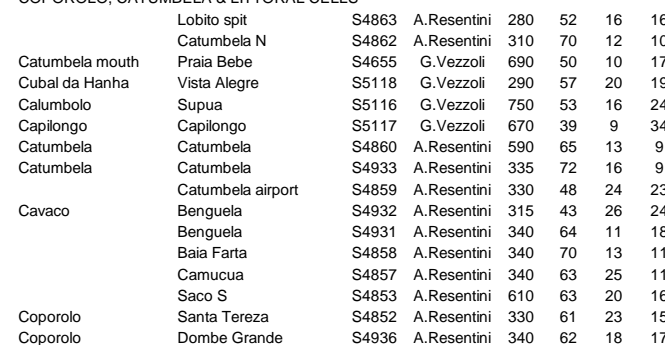

Coporolo IN Sombe Grande
BEACHES IN SOUTHERN ANGOLA

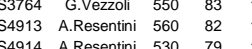

$\begin{array}{llll}\text { S4915 } & \text { A.Resentini } & 530 & 79 \\ & & 87\end{array}$

\begin{tabular}{|c|c|}
\hline & $\begin{array}{l}\text { Equimina } \\
\text { Baia Binga }\end{array}$ \\
\hline & $\begin{array}{l}\text { Bala Binga } \\
\text { Lucira }\end{array}$ \\
\hline low outer berm & Inamangando \\
\hline high inner berm & Inamangando \\
\hline & Baia das Salinas \\
\hline & Bentiaba \\
\hline & Chapeu Armado \\
\hline & Mariquita \\
\hline & Namibe \\
\hline RIVERS IN SOUTHE & RN ANGOLA \\
\hline Cangala & Santa Maria \\
\hline Carujamba & Lucira \\
\hline Inamangando & Inamangando \\
\hline Bentiaba & Bentiaba \\
\hline Giraul & Giraul \\
\hline Bero & Namibe \\
\hline CUNENE RIVER SY & STEM \\
\hline Cunene & Matala \\
\hline Mucope & Techiulo \\
\hline Caculuvar & Techango \\
\hline Caculuvar confluence & Omutele \\
\hline Cunene & Ruacana \\
\hline Ehomba & Ehomba \\
\hline Ondoto & Chitado \\
\hline Omuhongo & Etengua \\
\hline Omuhongo & Oryeheke \\
\hline Cunene & Epupa Falls \\
\hline Otjinjange & Van Zy's Pass \\
\hline Marienfluss & Otyoyonoka \\
\hline Cunene & Foz do Cunene \\
\hline ORANGE LITTORAL & CELL ONSHORE \\
\hline & Subida Grande \\
\hline fossil dune & Nonguai \\
\hline Curoca & Curoca mouth \\
\hline & Curoca mouth \\
\hline outer spit & Tombua \\
\hline eolian dune & Tombua \\
\hline & Vanesa \\
\hline eolian dune & Cova dos Medos \\
\hline & Vanesinha \\
\hline & Praia do Navio \\
\hline eolian dune & Praia do Navio \\
\hline eolian dune & Riscos \\
\hline & Riscos \\
\hline & Saco dos Tigres \\
\hline eolian dune & Praia dos Esponjas \\
\hline & Praia dos Esponja: \\
\hline olian & Foz do Cunene \\
\hline
\end{tabular}

S4937 A.Resentini $350 \quad 45$

$\begin{array}{llll}54916 & \text { A.Resentini } & 205 & 67 \\ \text { S4918 } & \text { A.Resentini } & 430 & 72 \\ \text { S4923 } & \text { A.Resentini } & 350 & 71\end{array}$

$\begin{array}{llll}S 4923 & \text { A.Resentini } & 350 & 71 \\ \text { S4930 A.Resentini } & 720 & 75\end{array}$

$\begin{array}{cccccc}\text { S4928 } & \text { A.Resentini } & 650 & 70 & 14 & 13 \\ 1011 & \text { G.Vezzoli } & 90 & 40 & 26 & 24\end{array}$

$\begin{array}{lllll}\text { S4917 } & \text { A.Resentini } & 130 & 82 & 6 \\ \text { S4922 } & \text { A.Resentini } & 350 & 73 & 16\end{array}$

$\begin{array}{llll}\text { S4922 } & \text { A.Resentini } & 350 & 73 \\ \text { S4924 } & \text { A.Resentini } & 335 & \end{array}$

$\begin{array}{lll}\text { S4924 } & \text { A.Resentini } & 335 \\ \text { S4925 } & \text { A.Resentini } & 260 \\ \text { S4926 } & \text { A.Resentini } & 500\end{array}$

$\begin{array}{lll}54926 & \text { A.Resentini } & 500 \\ 54927 & \text { A.Resentini } & 190\end{array}$ S49 
Table A4

Fon 言

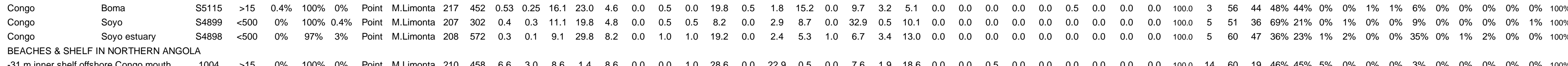

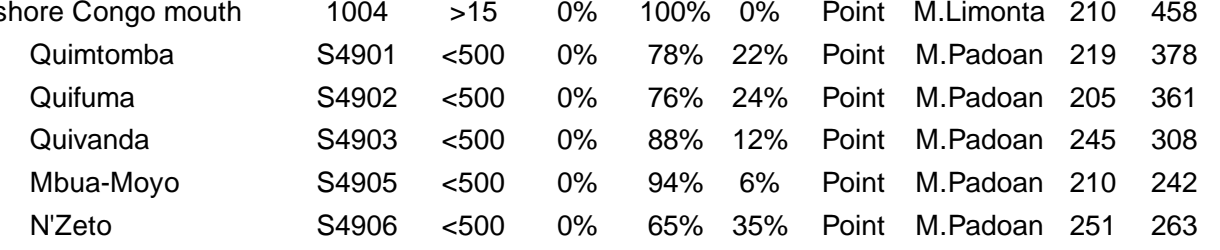

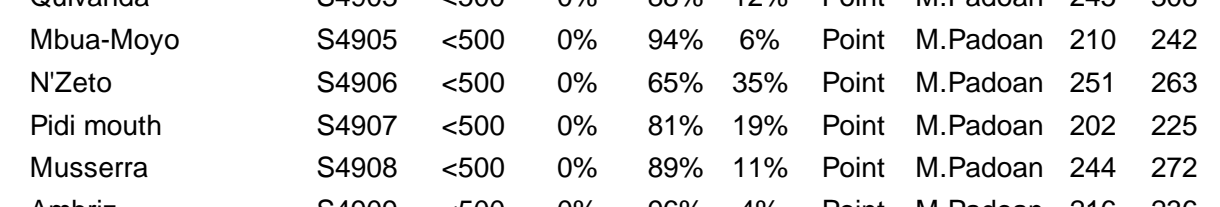

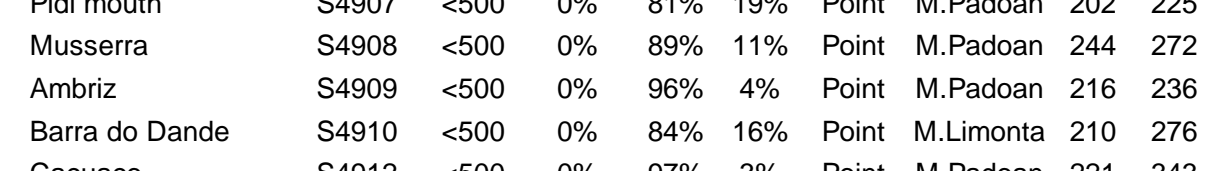

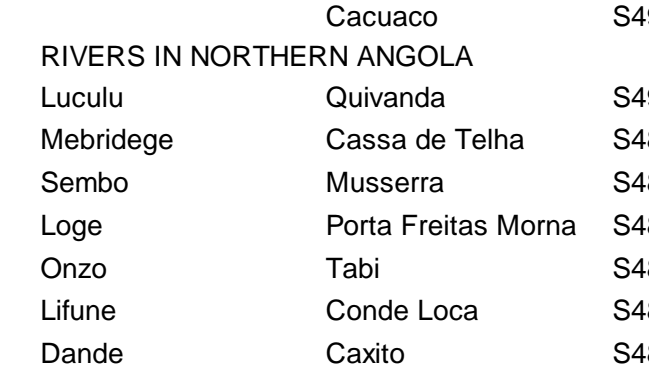

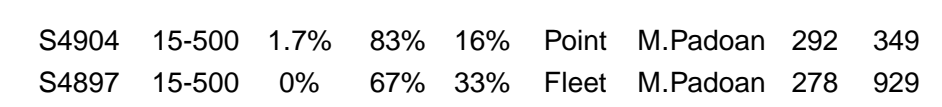

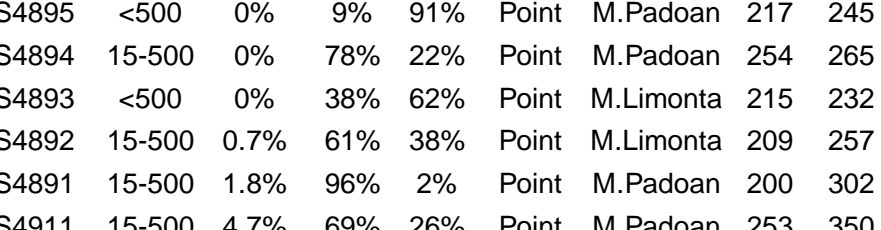

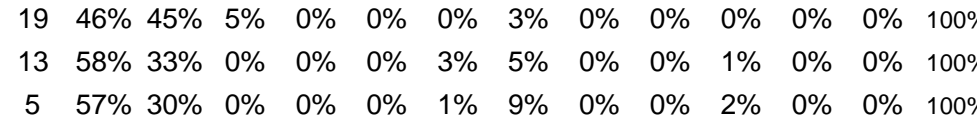

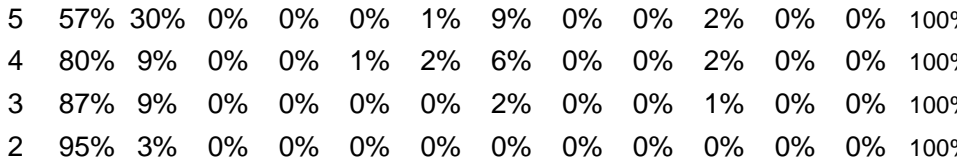

$\begin{array}{ll} & \\ & \end{array}$

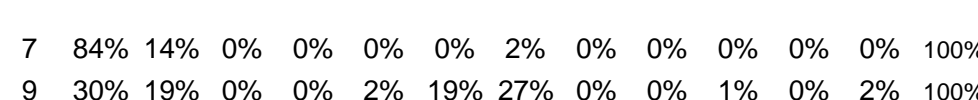
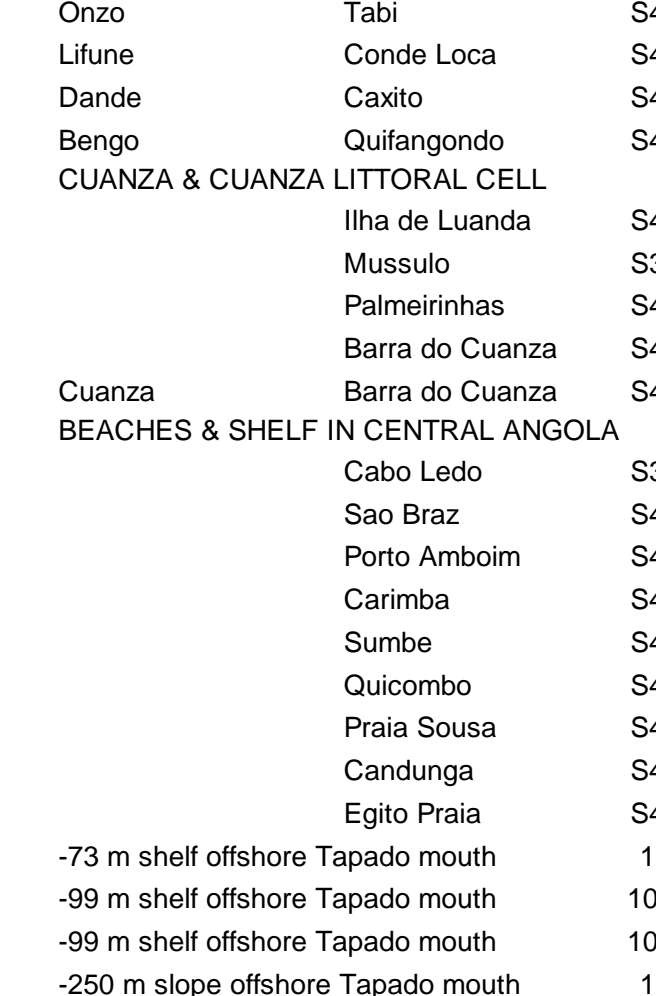

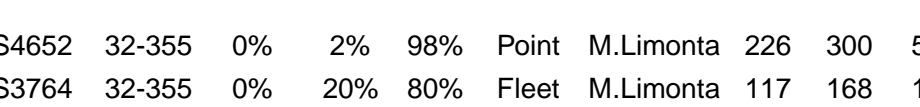

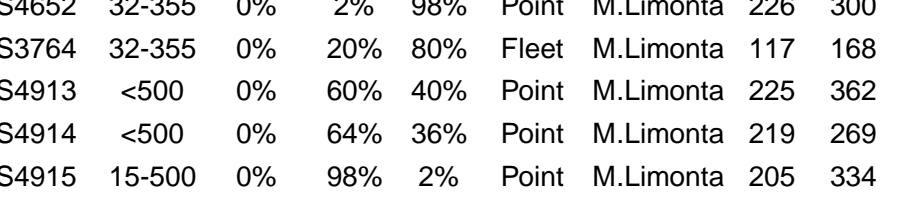

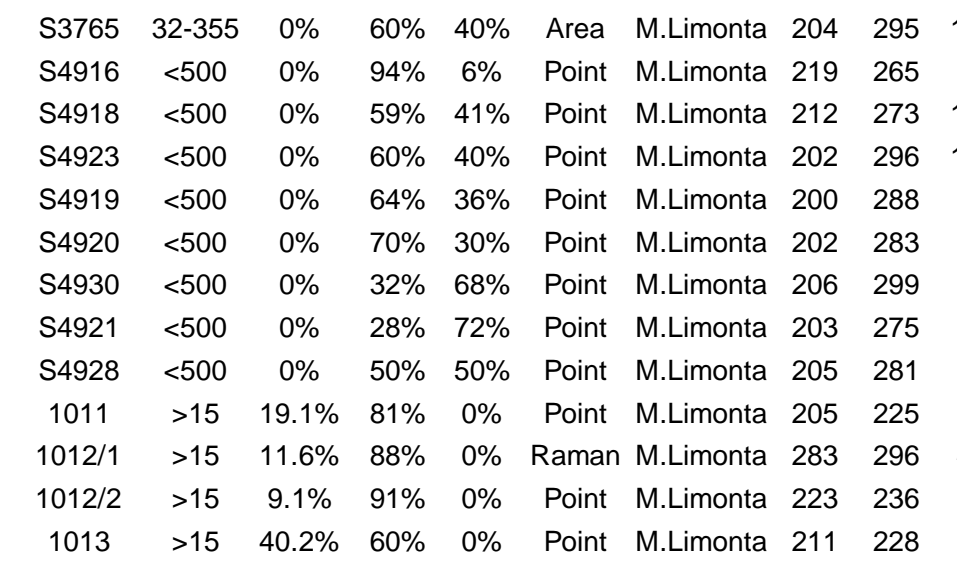

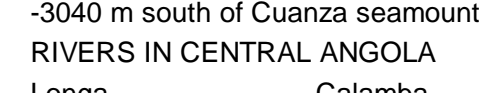

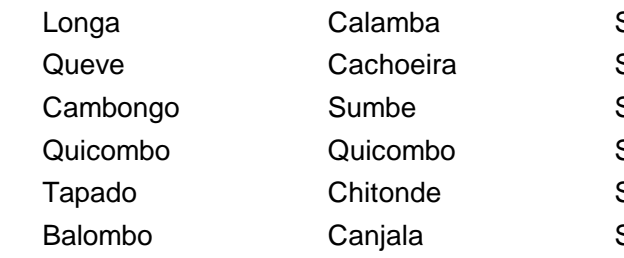

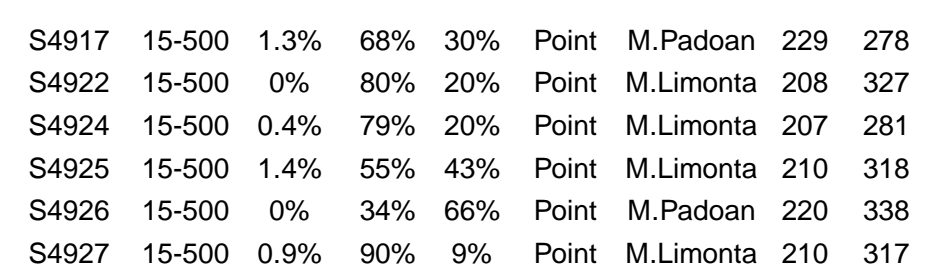

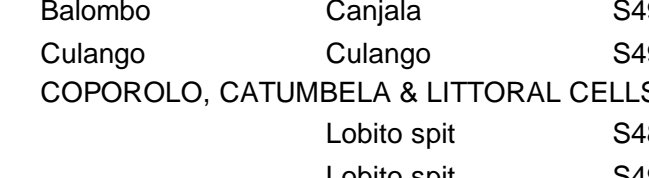

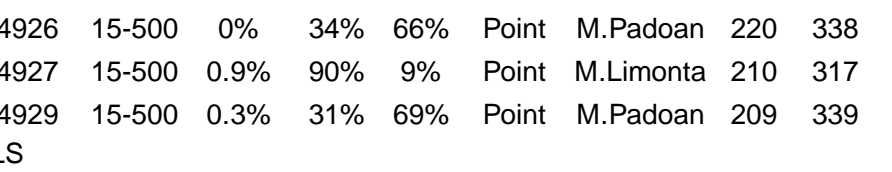

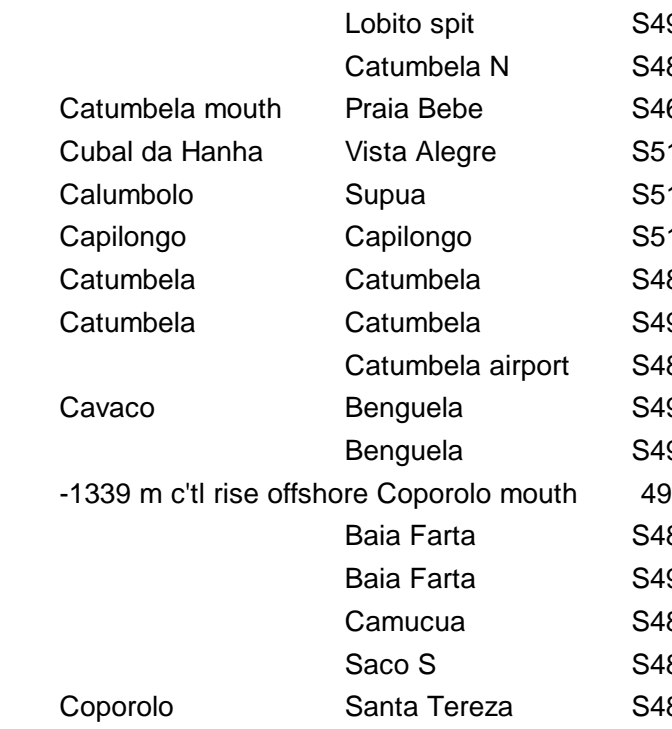

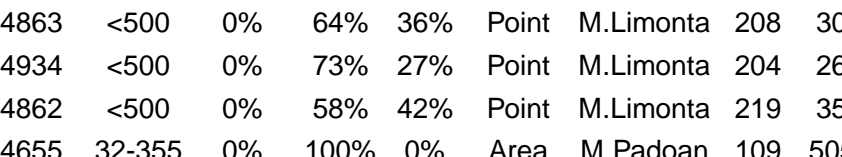

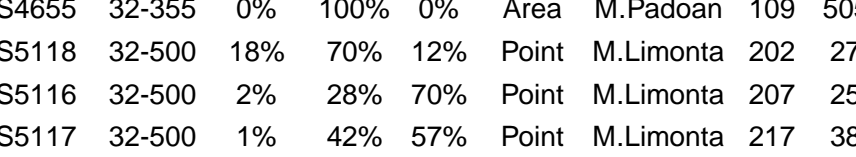

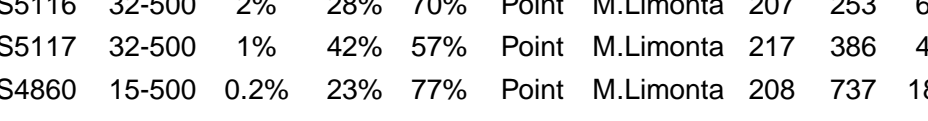

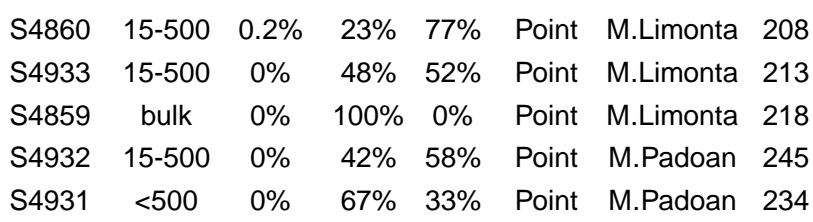

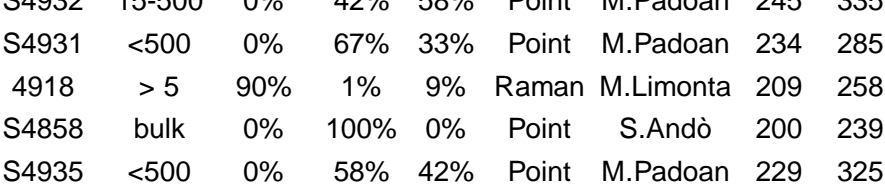

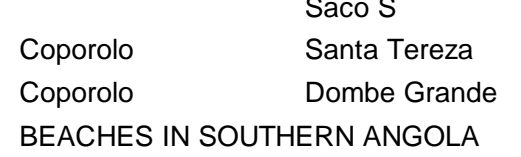

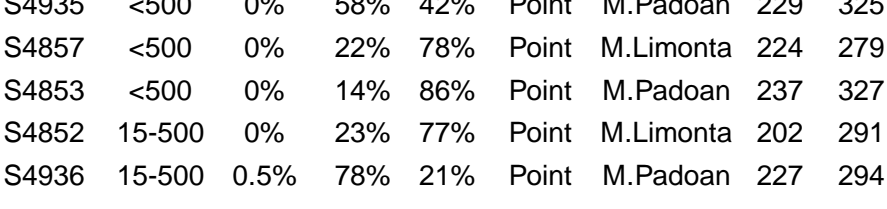

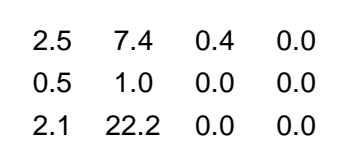

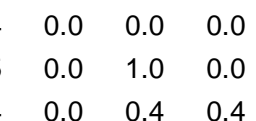

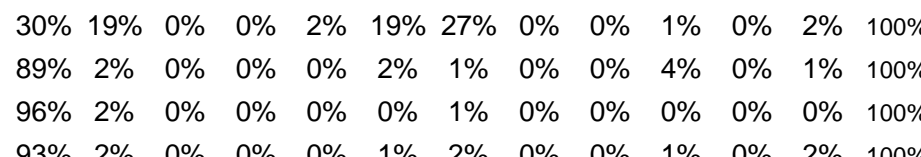

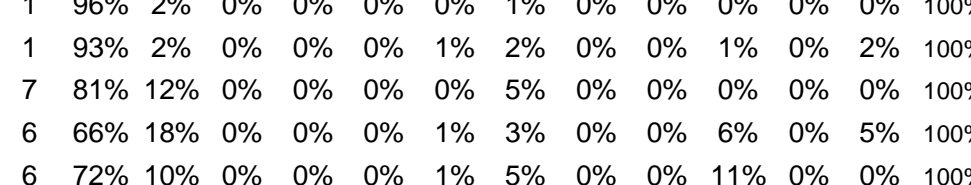

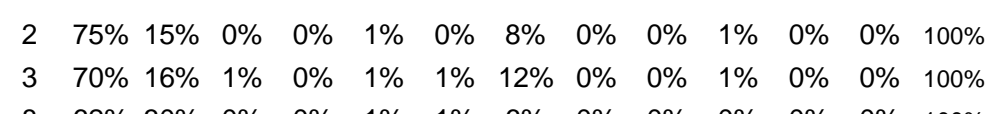

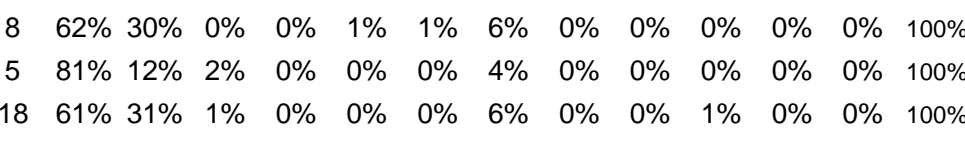

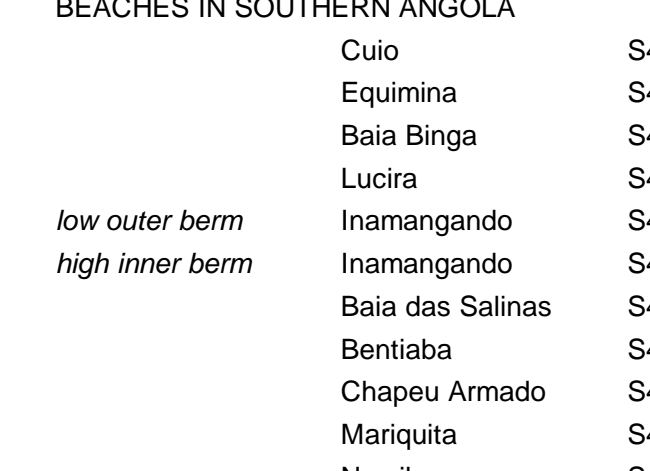

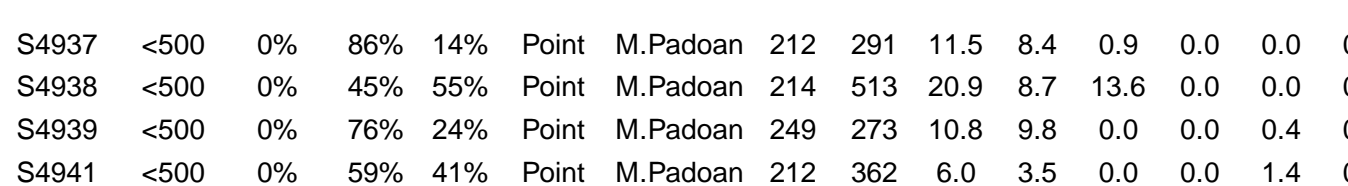

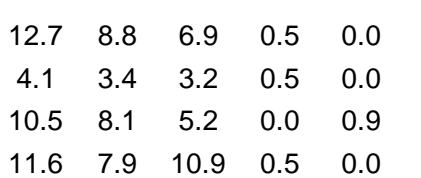

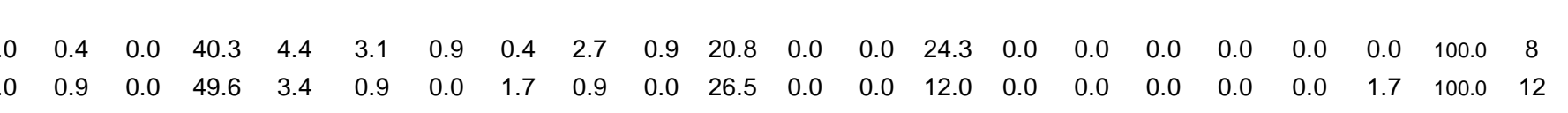

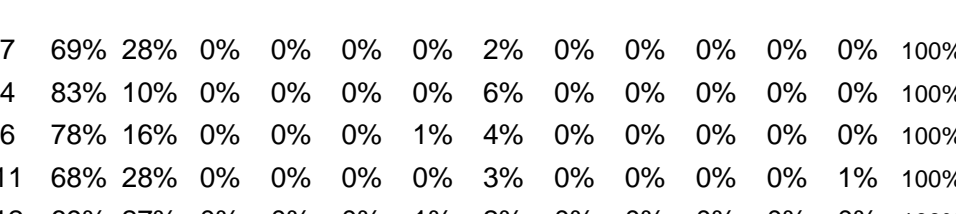

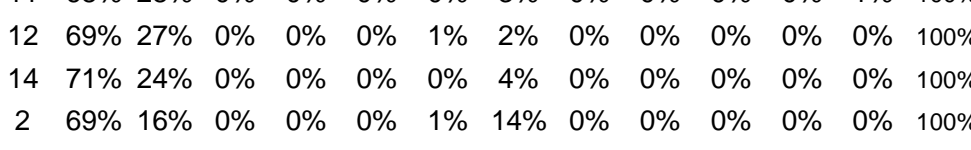

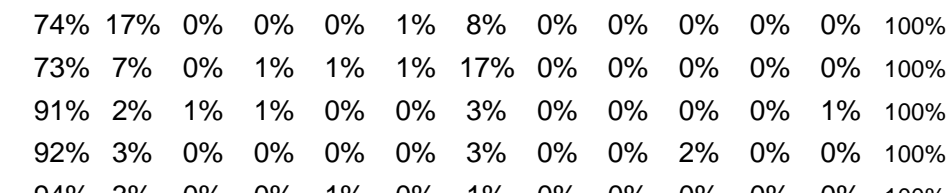

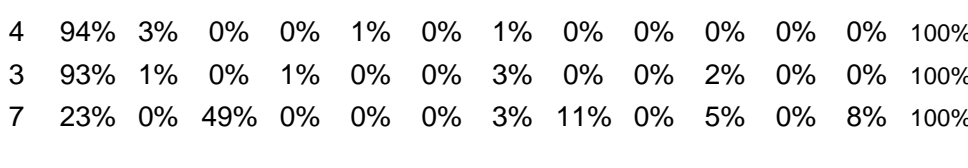

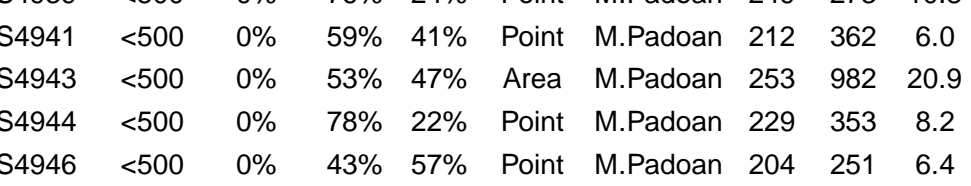

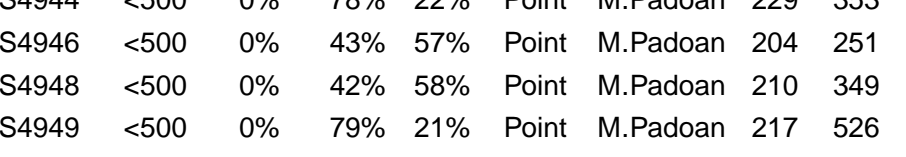

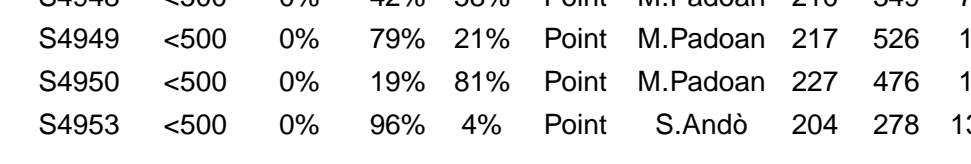

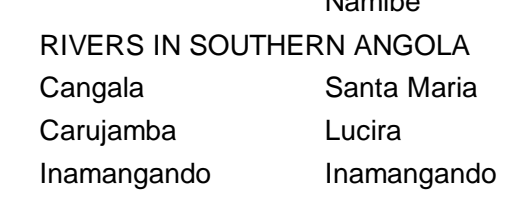

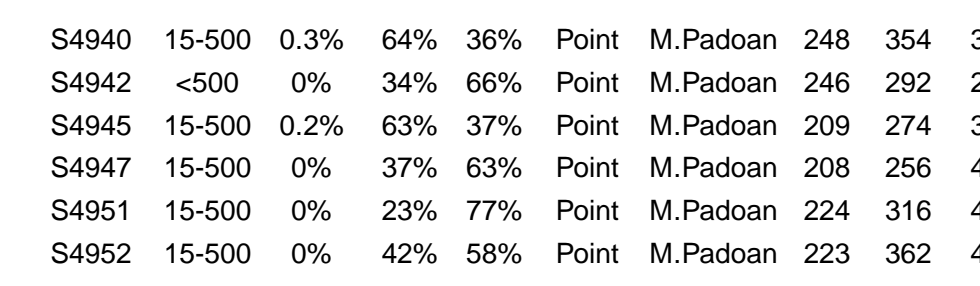

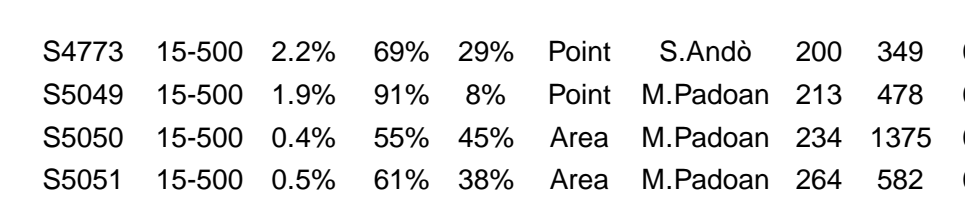

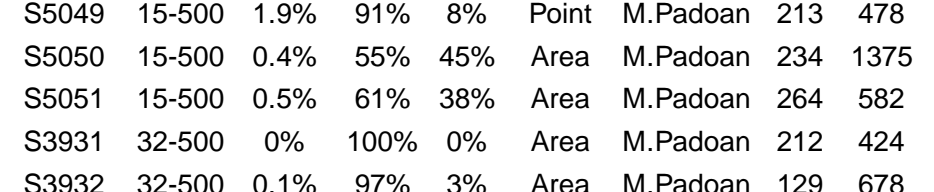

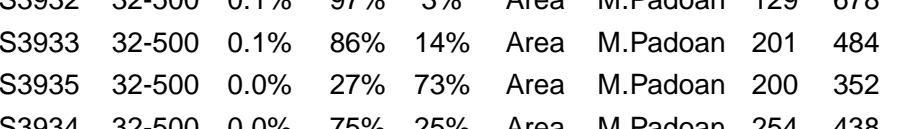

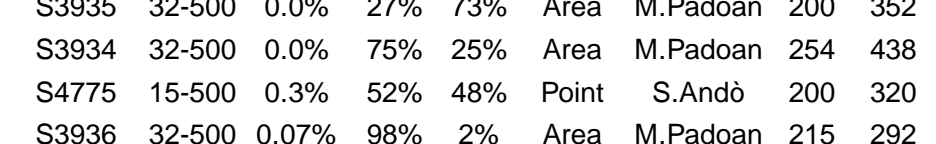

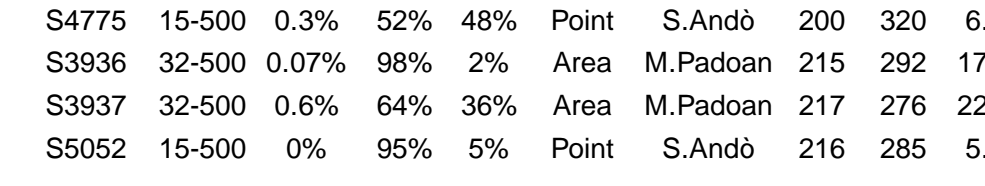

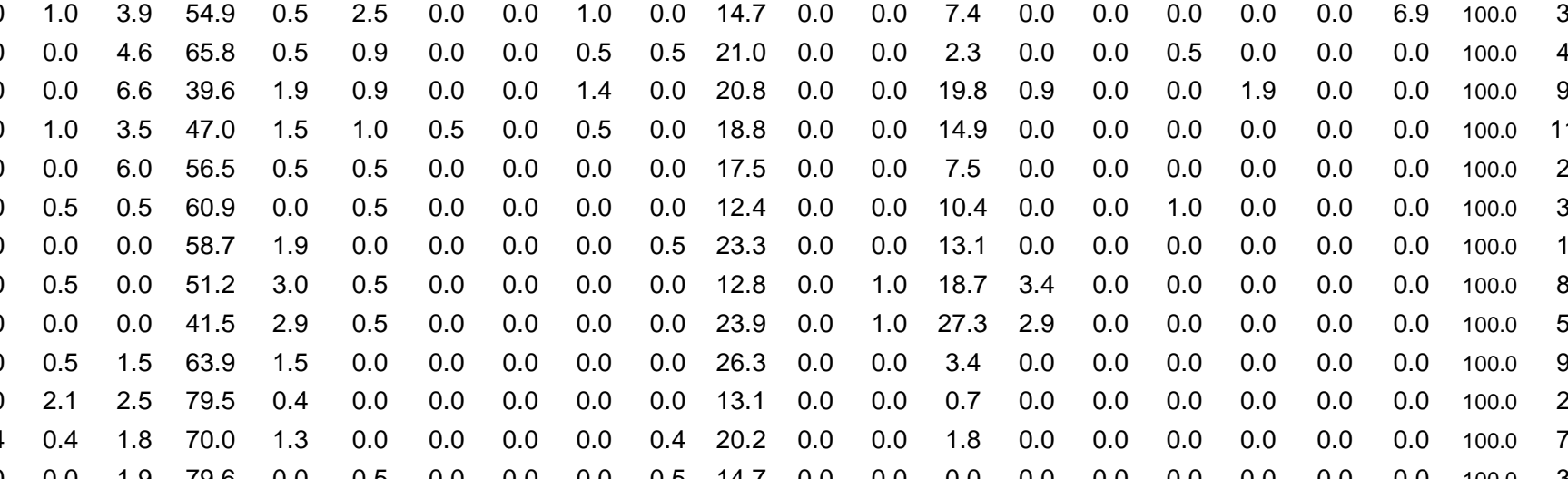

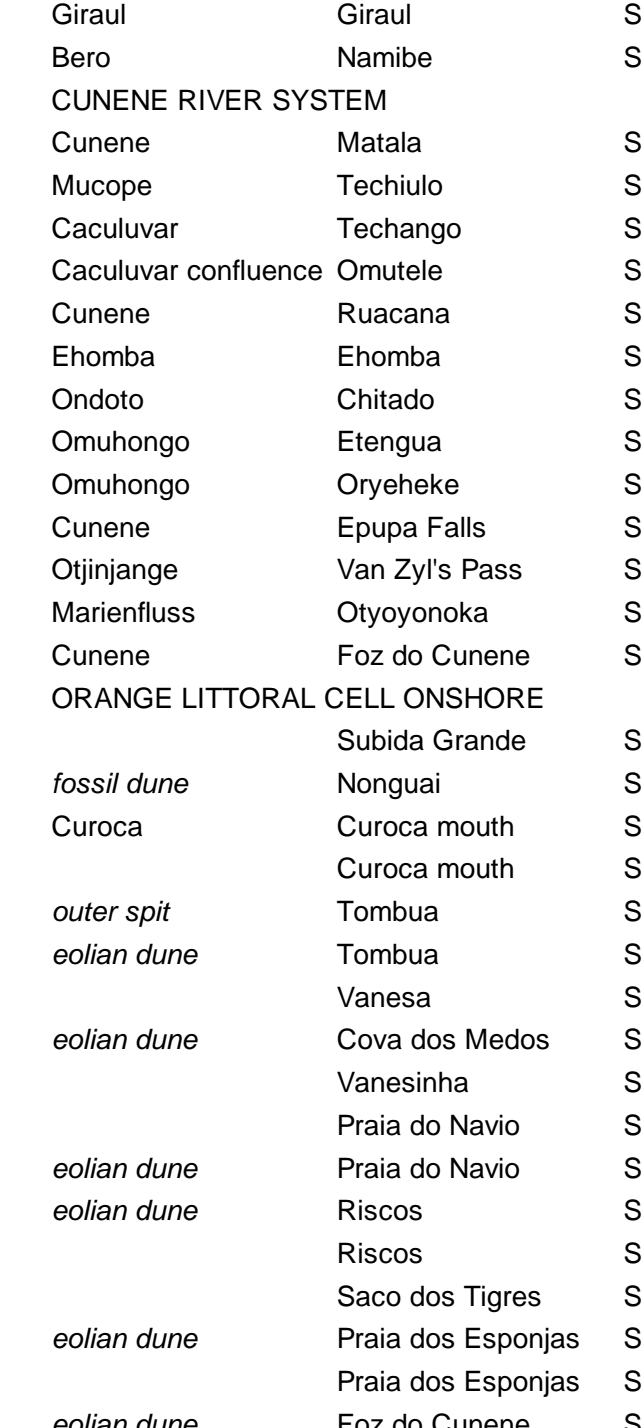

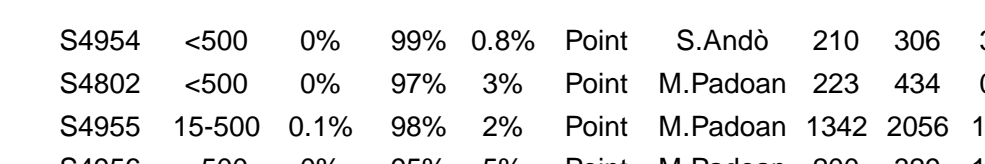

$\begin{array}{llllllll}0 & 0 & 0 \\ 0\end{array}$

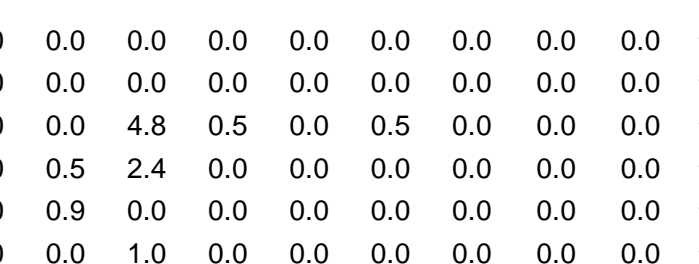

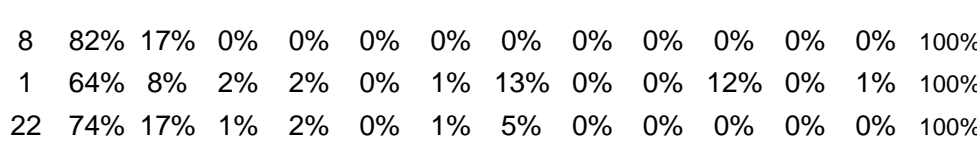

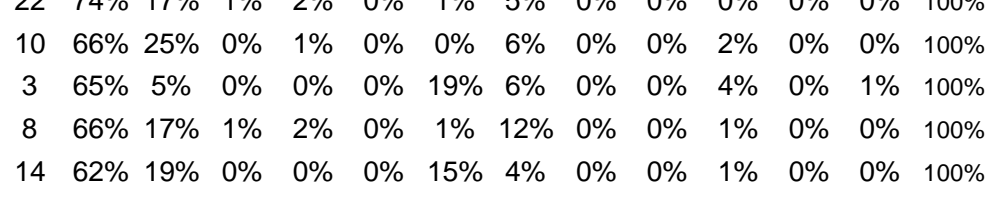

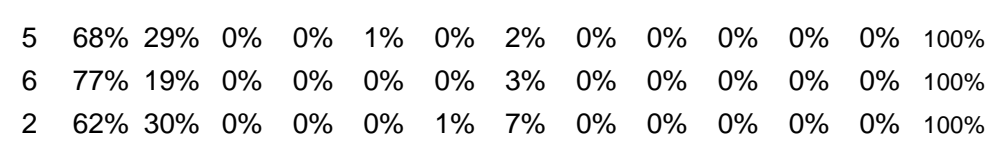

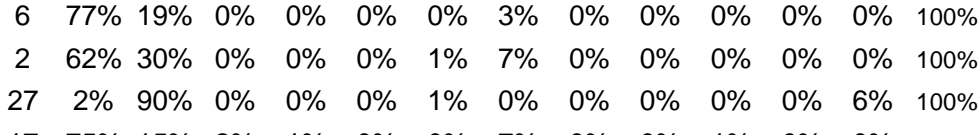

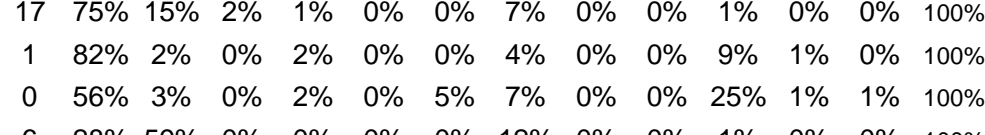

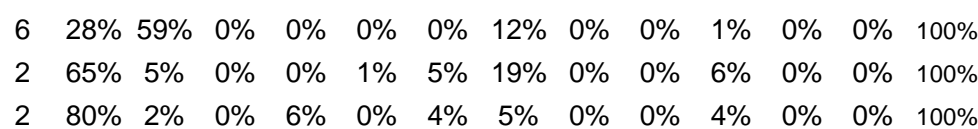

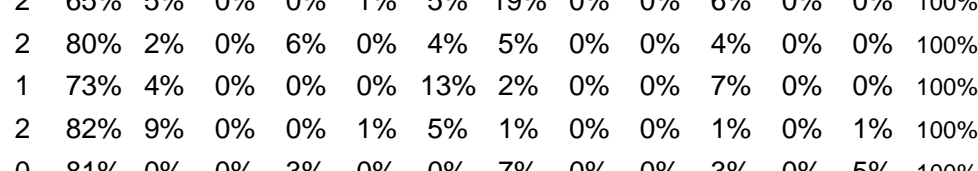

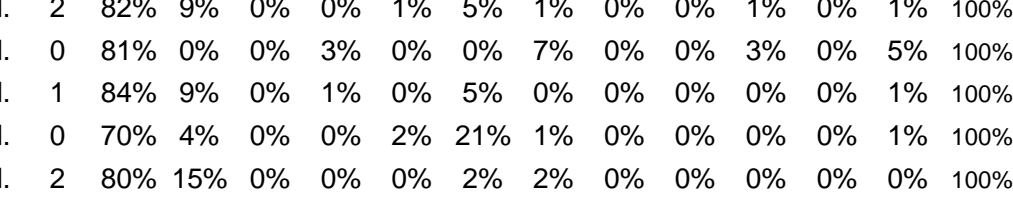

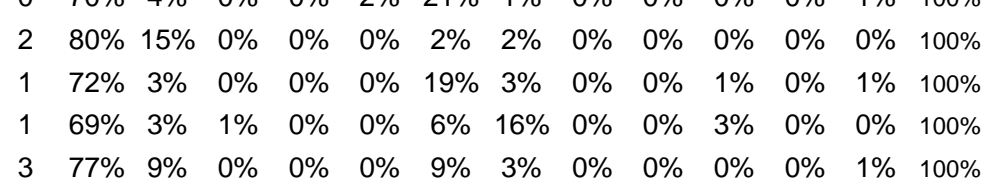

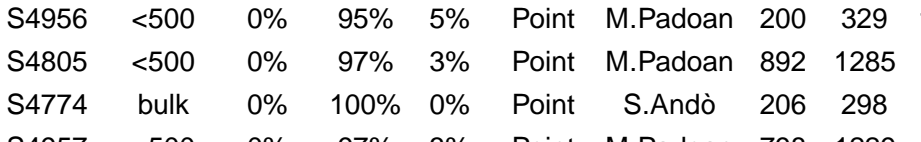

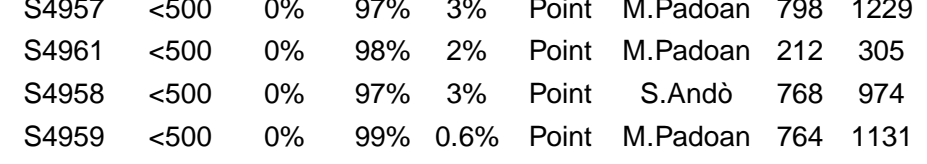

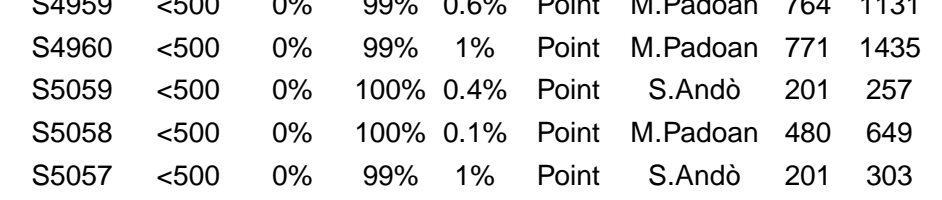

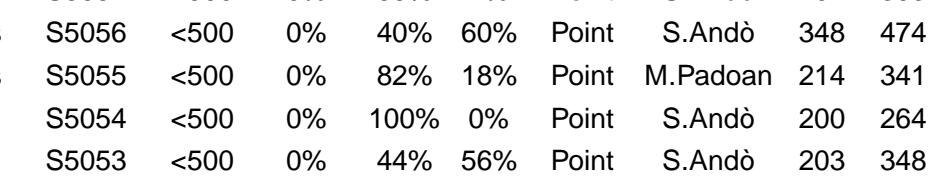

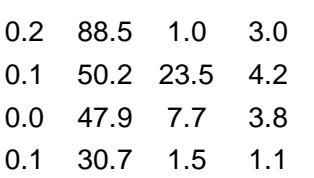

$\begin{array}{ll} & \\ 0 & \end{array}$

$\begin{array}{ll} & \\ & \end{array}$

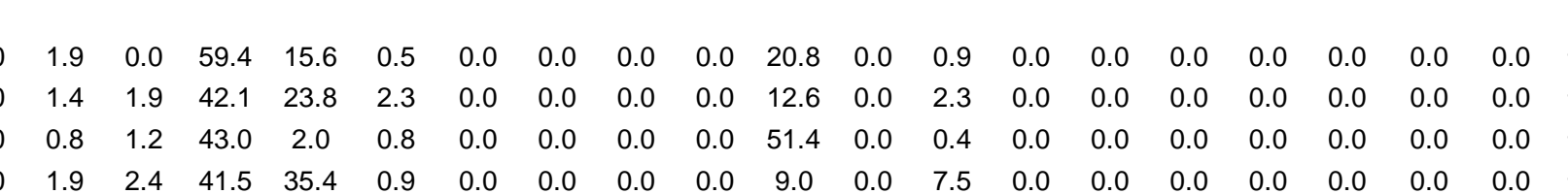

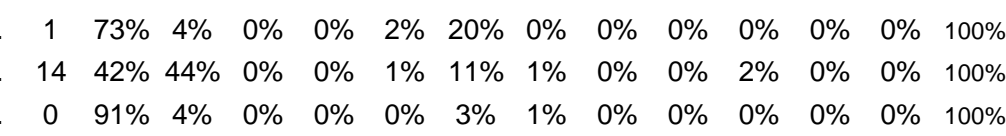

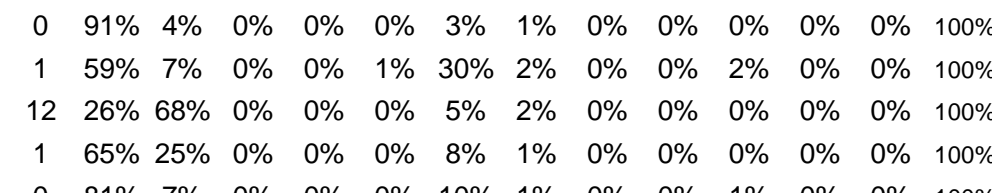

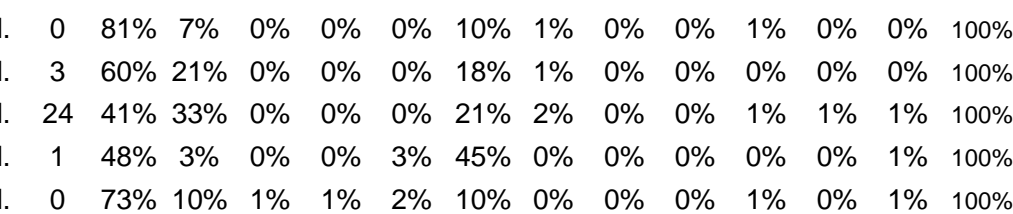

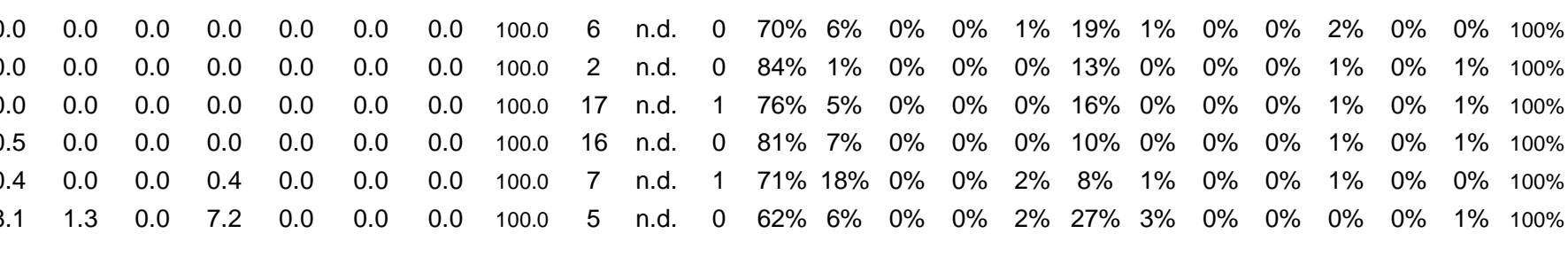

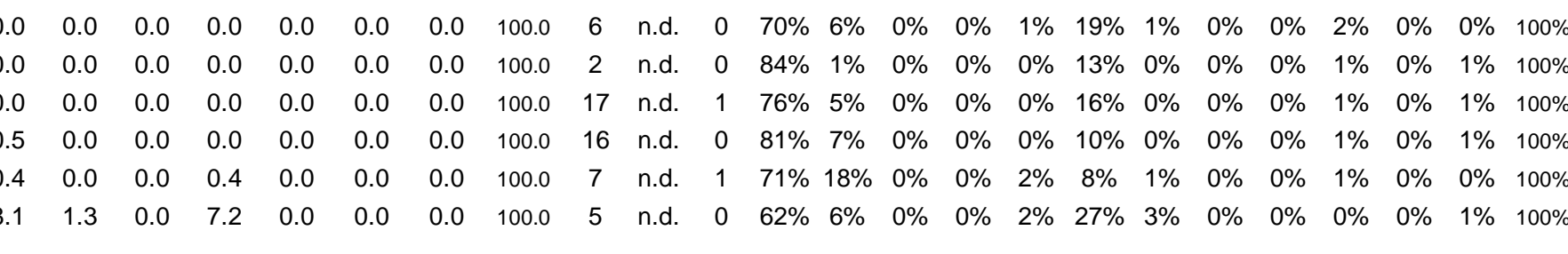

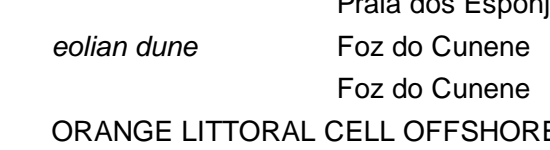

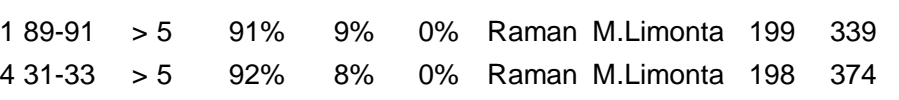

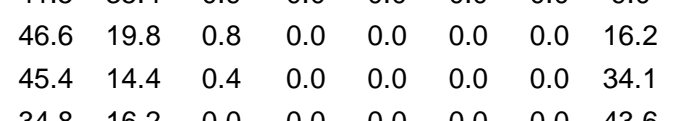

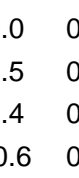

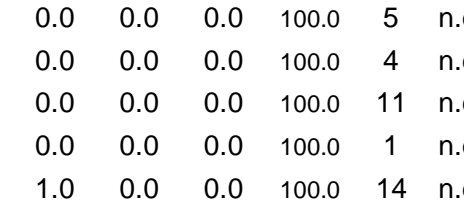

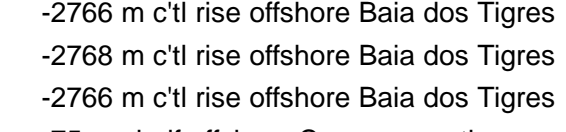

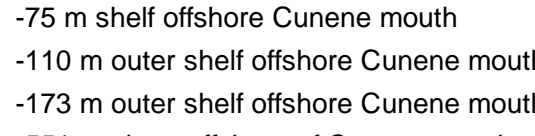

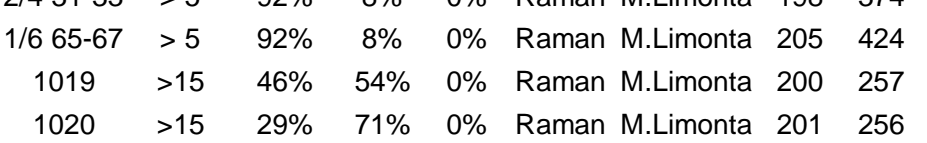

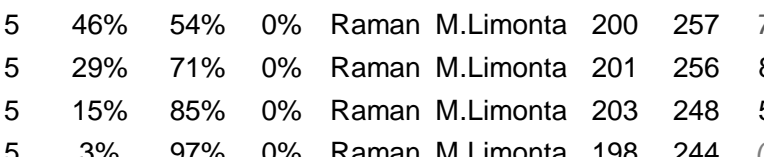

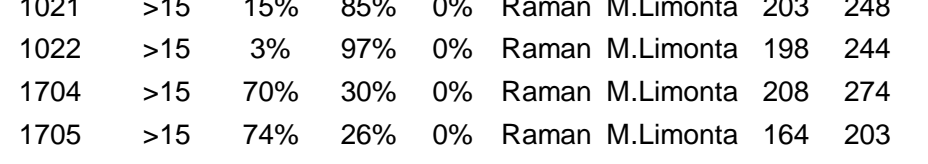




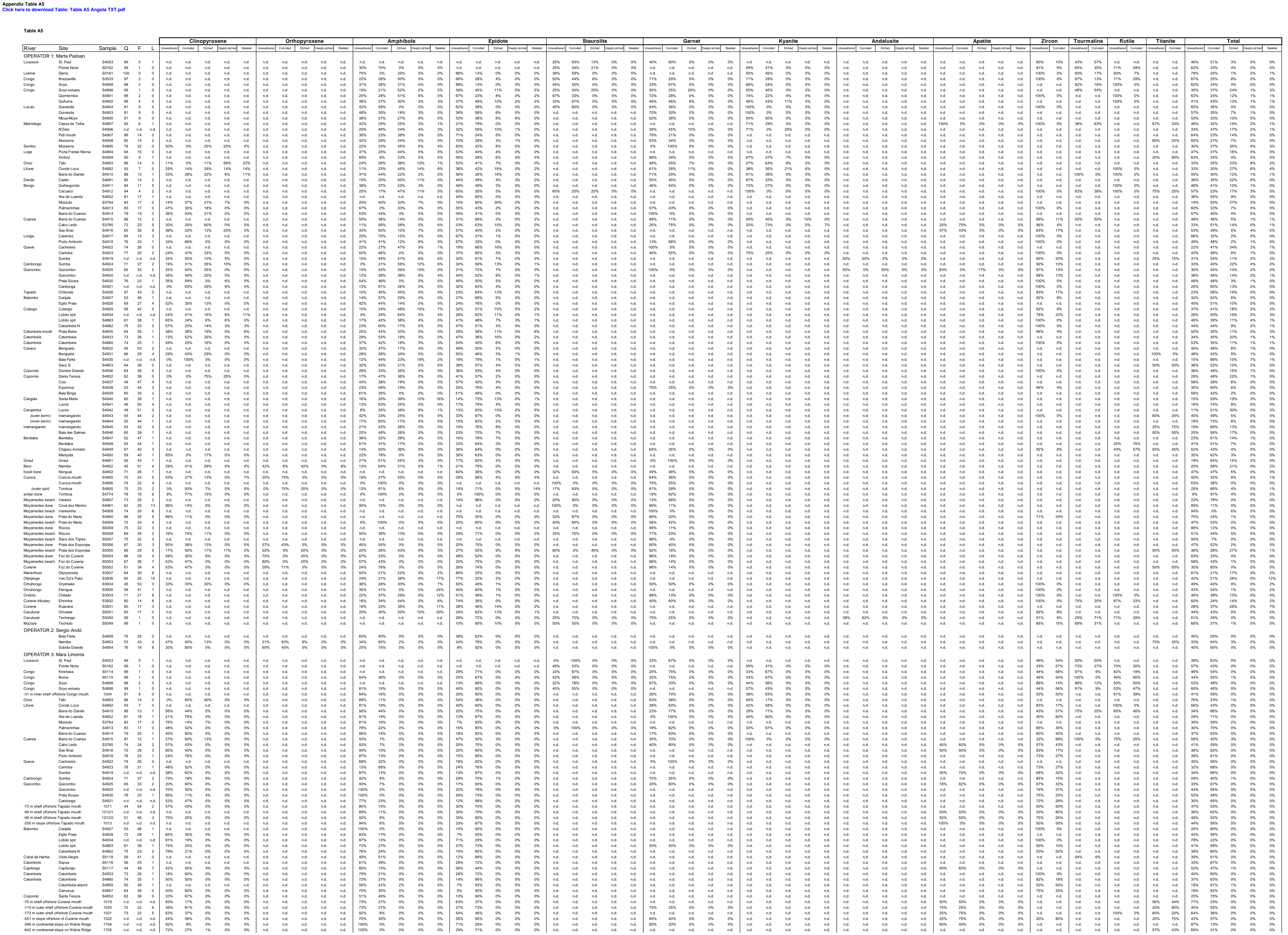


Table A6

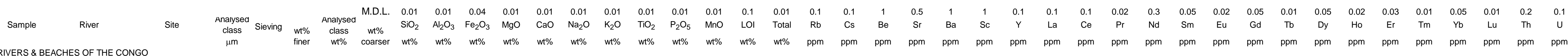

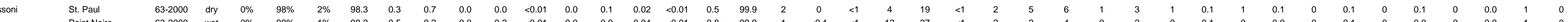

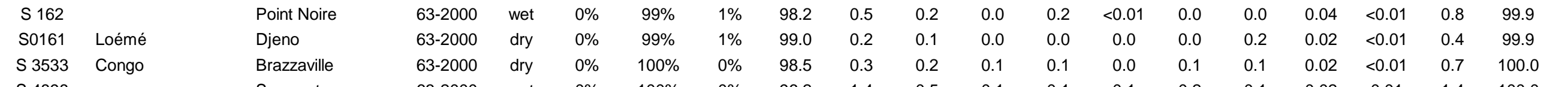

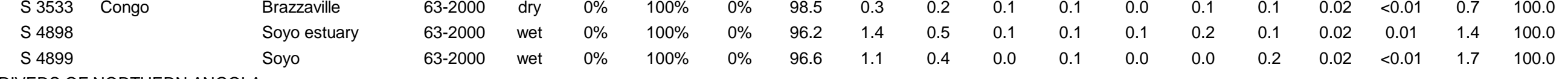

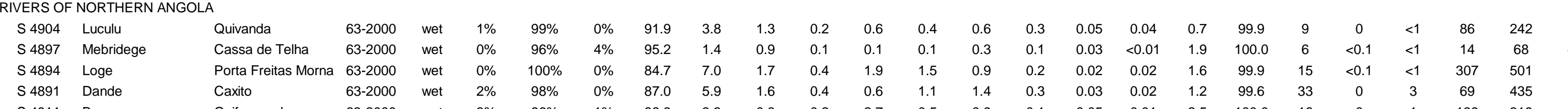

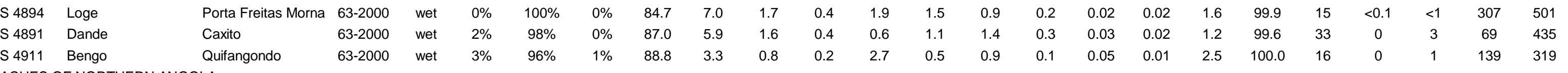

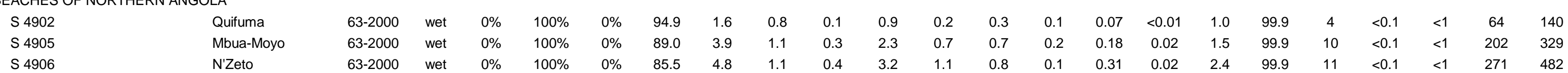

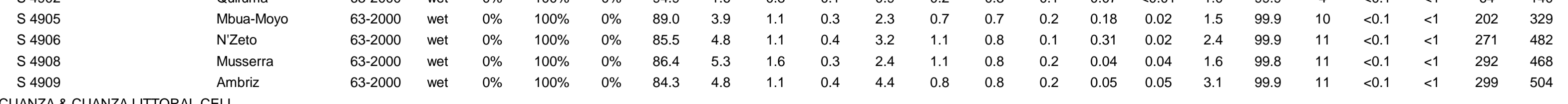

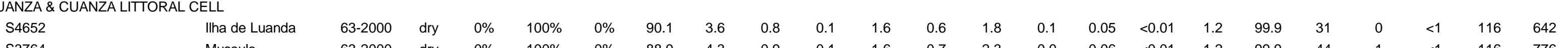
$\begin{array}{llllllllllllllllllllllll}\text { S3764 } & \text { Mussulo } & 63-2000 & \text { dry } & 0 \% & 100 \% & 0 \% & 88.9 & 4.3 & 0.9 & 0.1 & 1.6 & 0.7 & 2.3 & 0.0 & 0.06 & <.01 & 1.2 & 99.9 & 44 & 1 & <1 & 116 & 776 \\ \text { S 4915 Cuanza } & \text { Barad do Cuanza } & 63-2000 & \text { wet } & 0 \% & 100 \% & 0 \% & 93.5 & 2.3 & 0.5 & 0.1 & 0.5 & 0.2 & 0.8 & 0.1 & 0.03 & <0.01 & 1.8 & 100.0 & 16 & <0.1 & <1 & 41 & 288\end{array}$

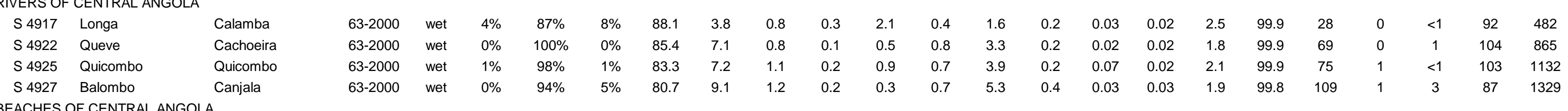

$S 3765$ F CENTRAL ANGOLA $\begin{array}{lllllllllllllllllllllllllll}\text { Cabo Ledo } & 63-2000 & \text { wet } & 0 \% & 100 \% & 0 \% & 76.9 & 5.7 & 2.4 & 0.6 & 6.0 & 0.8 & 2.2 & 0.5 & 0.18 & 0.05 & 4.3 & 99.8 & 42 & 0 & <1 & 272 & 2811 \\ \text { Port Amboim } & 63-2000 & \text { wet } & 0 \% & 100 \% & 0 \% & 84.2 & 5.6 & 1.9 & 0.6 & 2.8 & 0.8 & 2.0 & 0.4 & 0.24 & 0.04 & 1.1 & 99.9 & 38 & 0 & <1 & 192 & 658 & \end{array}$ S $4934 \quad$ Lobito spit 63-2000 wet $\quad \begin{array}{lllllllllllllllllllllll} & 0 \% & & 0 & 0 & 79.7 & 8.1 & 3.4 & 0.6 & 2.1 & 1.4 & 2.8 & 0.9 & 0.07 & 0.06 & 0.6 & 99.8 & 57 & 0 & <1 & 243 & 870\end{array}$

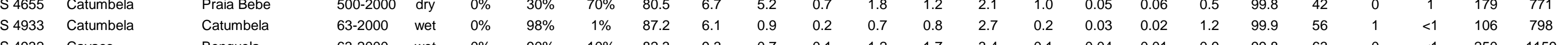

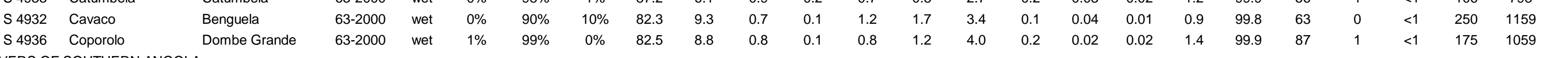
$\begin{array}{lllllllllllllllllllllll}\text { S 4940 Cangala } & \text { Canta Maria } & 63-2000 & \text { wet } & 0 \% & 100 \% & 0 \% & 79.0 & 11.1 & 1.0 & 0.2 & 1.4 & 2.4 & 3.7 & 0.2 & 0.04 & 0.02 & 0.7 & 99.9 & 74 \\ \text { S S945 } & \text { Inamangando } & \text { Inamangando } & 63-2000 & \text { wet } & 1 \% & 96 \% & 4 \% & 79.6 & 10.2 & 1.4 & 0.3 & 1.9 & 2.0 & 3.0 & 0.2 & 0.06 & 0.02 & 1.2 & 998 & & \end{array}$

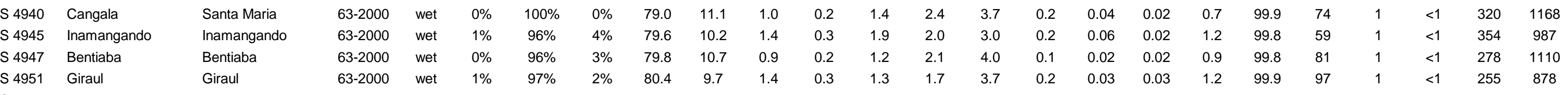
$\mathrm{S} 4952$ Bero $\quad$ Giraul S $4938 \quad$ Eq

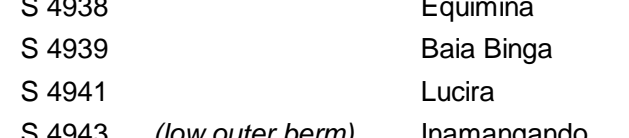
$\begin{array}{lll}\mathrm{S} 4943 & \text { (low outer berm) } & \text { Inamangando } \\ \mathrm{S} 4944 & \text { (high inner berm) } & \text { Inamangando }\end{array}$ S 4948 SUNENE RIVER SYSTEM S3934 Omuhongo $\quad$ Rucanenake S4775 CUnene
ORANGE LITORAL CELL $\begin{array}{lllllllllllllllllllllll}63-2000 & \text { wet } & 1 \% & 97 \% & 2 \% & 80.4 & 9.7 & 1.4 & 0.3 & 1.3 & 1.7 & 3.7 & 0.2 & 0.03 & 0.03 & 1.2 & 99.9 & 97 & 1 & <1 & 255 & 878 \\ 63-2000 & \text { wet } & 0 \% & 99 \% & 1 \% & 77.1 & 10.7 & 2.1 & 0.8 & 2.1 & 2.1 & 2.9 & 0.3 & 0.05 & 0.04 & 1.7 & 99.8 & 74 & 1 & <1 & 320 & 916 & 5\end{array}$ $\begin{array}{lllllllllllllllllllllll}63-2000 & \text { wet } & 0 \% & 94 \% & 5 \% & 71.8 & 11.0 & 5.7 & 0.3 & 2.5 & 2.4 & 2.7 & 1.6 & 0.09 & 0.17 & 1.3 & 99.5 & 49 & 1 & <1 & 358 & 906 \\ 63-2000 & \text { wet } & 0 \% & 100 \% & 0 \% & 71.9 & 11.0 & 1.6 & 0.8 & 6.0 & 2.9 & 1.9 & 0.3 & 0.05 & 0.03 & 3.4 & 99.8 & 30 & 0 & <1 & 449 & 703 \\ 63-2000 & \text { wet } & 0 \% & 97 \% & 3 \% & 74.1 & 12.9 & 1.8 & 0.5 & 3.3 & 3.0 & 2.2 & 0.2 & 0.06 & 0.03 & 1.8 & 99.8 & 40 & 1 & 2 & 463 & 866\end{array}$ $\begin{array}{lllllllllllllllllllllll}63-2000 & \text { wet } & 0 \% & 97 \% & 3 \% & 74.1 & 12.9 & 1.8 & 0.5 & 3.3 & 3.0 & 2.2 & 0.2 & 0.06 & 0.03 & 1.8 & 99.8 & 40 & 1 & 2 & 463 & 866 \\ 63-2000 & \text { wet } & 0 \% & 100 \% & 0 \% & 71.7 & 8.9 & 10.2 & 0.2 & 1.5 & 1.7 & 2.9 & 1.6 & 0.06 & 0.14 & 0.8 & 99.6 & 64 & 1 & <1 & 279 & 904 \\ 63-2000 & \text { wet } & 0 \% & 99 \% & 1 \% & 78.2 & 10.1 & 2.0 & 0.3 & 2.0 & 1.9 & 3.4 & 0.3 & 0.04 & 0.04 & 1.5 & 99.8 & 70 & 1 & 1 & 306 & 911\end{array}$

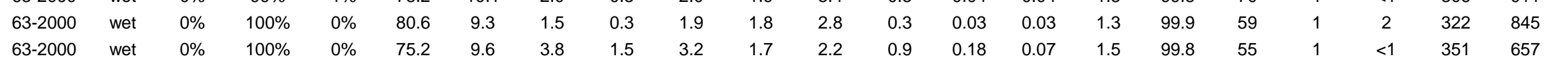
$\begin{array}{lll}\text { S } 4955 & \text { Curoca } & \text { Curoca mouth } \\ \text { S } 4774 & \text { Mocamedes dune } & \text { Tombua }\end{array}$

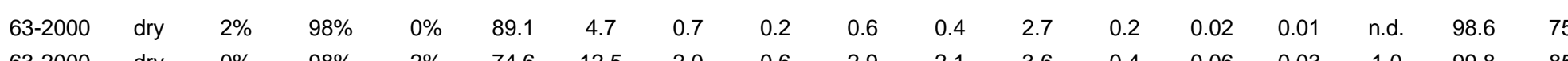
$\begin{array}{cc}60 & 587 \\ 237 & 1062 \\ 257 & 710\end{array}$ $\begin{array}{rllllllllllllllllll}63-2000 & \text { wet } & 0 \% & 100 \% & 0 \% & 81.4 & 6.1 & 2.7 & 1.0 & 3.3 & 1.2 & 1.2 & 0.5 & 0.88 & 0.08 & 1.5 & 99.9 & 37 \\ 63-2000 & \text { wet } & 0 \% & 100 \% & 0 \% & 86.0 & 5.8 & 1.4 & 0.4 & 1.7 & 1.1 & 1.3 & 0.2 & 0.37 & 0.07 & 1.8 & 100.0 & 41 \\ \end{array}$

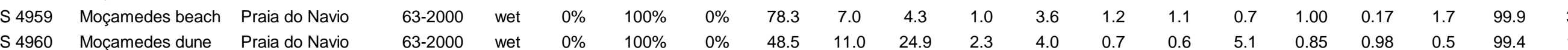




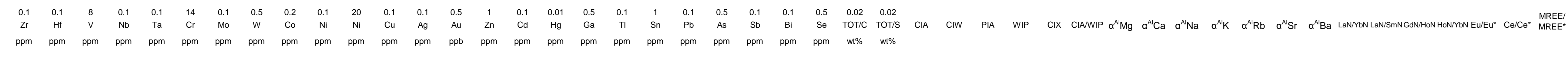

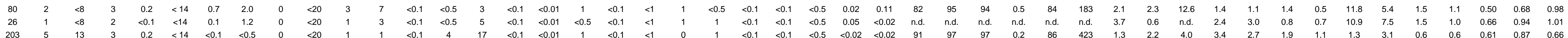

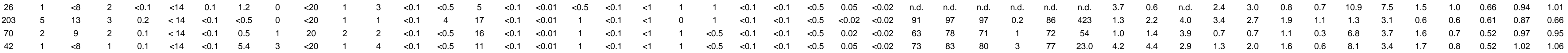

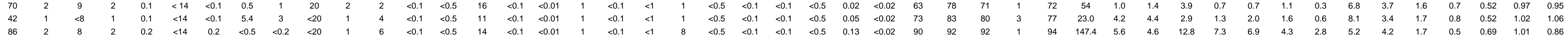

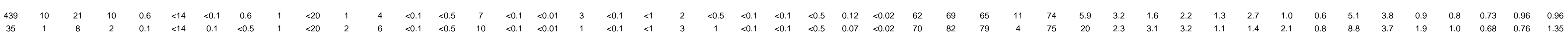

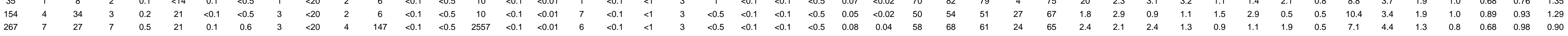

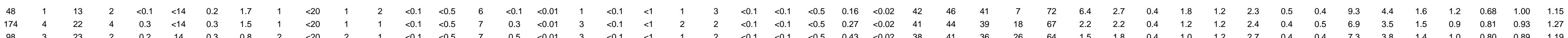

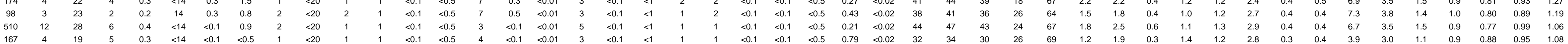

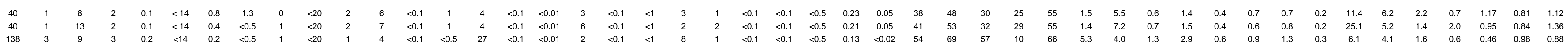

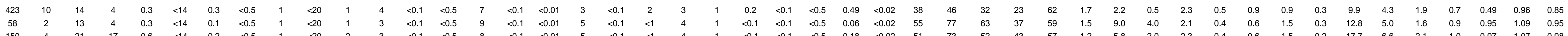

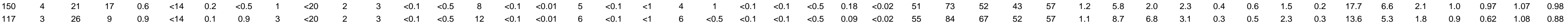

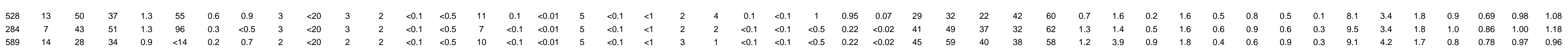

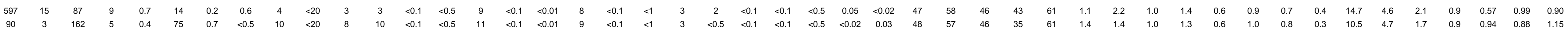

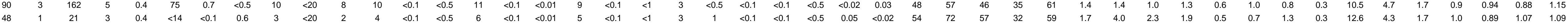

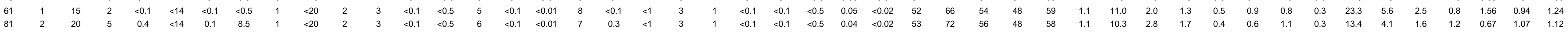

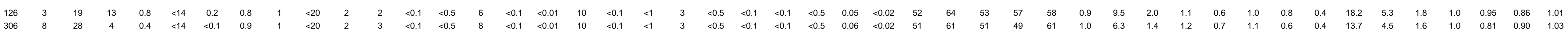

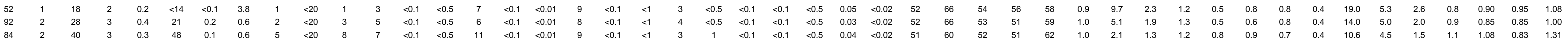
$\begin{array}{cccccccccc}2474 & 49 & 88 & 93 & 5.5 & 27 & 0.3 & <0.5 & 3 & <20 \\ 88 & 2 & 44 & 7 & 0.5 & 21 & 0.2 & 1.2 & 3 & <20\end{array}$ $\begin{array}{lllllllllll}71 & 2 & 35 & 3 & 0.2 & 14 & 0.2 & <.5 & 5 & 20 \\ 685 & 16 & 171 & 33 & 2.0 & 68 & 0.1 & 1.1 & 4 & 20 \\ 168 & 5 & 39 & 6 & 0.4 & 14 & 0.1 & 7.4 & 2 & 20 \\ 72 & 2 & 2 & 5 & 0 & -4 & 0.1 & 1.0 & 2 & 20 & 1\end{array}$ $\begin{array}{ccccccccccccccccc}4 & <0.1 & <0.5 & 22 & <0.1 & <0.01 & 11 & <0.1 & 2 & 5 & <0.5 & <0.1 & <0.1 & <0.5 & 0.07 & <0.02 & 50 \\ 3 & <0.1 & <0.5 & 6 & <0.1 & <0.01 & 10 & <0.1 & <1 & 2 & 1 & <0.1 & <0.1 & <0.5 & 0.77 & <0.02 & 38\end{array}$

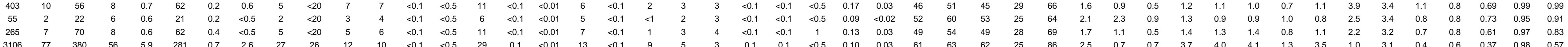




\begin{tabular}{|c|c|c|c|c|c|}
\hline Sample S4899 & Cong & stuary @ Soy & & $06^{\circ} 07^{\prime} 52^{\prime \prime} \mathrm{S}$ & $12^{\circ} 22^{\prime} 25^{\prime \prime} \mathrm{E}$ \\
\hline & concentrations & & & isotopic ratios & \\
\hline grain & $\mathrm{U}[\mathrm{ppm}]$ & $\mathrm{Pb}$ [ppm] & $\mathrm{Th} / \mathrm{U}$ & Pb207/Pb206 & 2076 \\
\hline X4899_G001 & 66.8 & & 0.4933 & 0.06015 & 0.0026 \\
\hline X4899_G002 & 44.3 & 20.1 & 0.9887 & 0.12093 & 0.0036 \\
\hline X4899_G003 & 190.5 & 78.9 & 0.7495 & 0.12353 & 0.0033 \\
\hline X4899_G004 & 151.4 & 28.8 & 0.6165 & 0.07311 & 0.0022 \\
\hline X4899 G005 & 188.9 & 103.9 & 0.5412 & 0.23891 & 0.00608 \\
\hline X4899 G006 & 279 & 23.4 & 0.2793 & 0.05939 & 0.00184 \\
\hline X4899 G007 & & & & 0.82317 & 0.0387 \\
\hline X4899 G008 & 217.4 & 24.8 & 0.6058 & 0.06881 & 0.0021 \\
\hline X4899_G009 & 106.3 & 63 & 0.7073 & 0.17606 & 0.00468 \\
\hline X4899_G010 & 1148.8 & 102.1 & 0.8968 & 0.54374 & 0.01378 \\
\hline X4899_G011 & 156.9 & 12.5 & 0.0071 & 0.05823 & 0.00204 \\
\hline X4899_G012 & 135.6 & 15.3 & 1.033 & 0.05771 & 0.00204 \\
\hline X4899_G013 & 131.6 & 72 & 1.3843 & 0.12932 & 0.00356 \\
\hline X4899_G014 & 94.8 & 9.5 & 0.6306 & 0.05868 & 0.00232 \\
\hline X4899_G015 & 16.6 & 8 & 0.7369 & 0.13699 & 0.00484 \\
\hline X4899_G016 & 79.4 & 8.8 & 0.4513 & 0.06046 & 0.00252 \\
\hline X4899 G017 & 43.1 & 4.6 & 0.3457 & 0.06011 & 0.00306 \\
\hline X4899 G018 & 260.8 & 139.5 & 0.6076 & 0.1814 & 0.00474 \\
\hline X4899 G019 & 273.1 & 154.9 & 0.801 & 0.1767 & 0.00452 \\
\hline X4899 G020 & 226.1 & 13.1 & 2.4728 & 0.3015 & 0.01016 \\
\hline X4899_G021 & 720.8 & 156.4 & 1.54 & 0.28769 & 0.0074 \\
\hline X4899_G022 & 307.9 & 37.2 & 0.1472 & 0.16054 & 0.00436 \\
\hline X4899_G023 & 75.5 & 47.6 & 0.8969 & 0.18146 & 0.00488 \\
\hline X4899_G024 & 398.4 & 44.8 & 1.5353 & 0.05624 & 0.00172 \\
\hline X4899_G025 & 129.6 & 53.5 & 0.4224 & 0.13206 & 0.00362 \\
\hline X4899_G026 & 176.7 & $\begin{array}{l}20.3 \\
88.2\end{array}$ & 0.8925 & $\begin{array}{l}0.06384 \\
0.26621\end{array}$ & $\begin{array}{r}0.00214 \\
0.0069\end{array}$ \\
\hline $\begin{array}{l}\text { X4899_G027 } \\
\text { X4899_G028 }\end{array}$ & $\begin{array}{l}148.2 \\
108.7\end{array}$ & $\begin{array}{l}88.2 \\
15.3\end{array}$ & $\begin{array}{l}0.2682 \\
0.1153\end{array}$ & $\begin{array}{r}0.26621 \\
0.0922\end{array}$ & $\begin{array}{r}0.0069 \\
0.00298\end{array}$ \\
\hline $\begin{array}{l}\text { X4899_GU28 } \\
\times 4899 \text { G029 }\end{array}$ & $\begin{array}{l}148.6 \\
214.6\end{array}$ & $\begin{array}{l}15.3 \\
46.6\end{array}$ & 0.3716 & $\begin{array}{l}0.0922 \\
0.09458\end{array}$ & $\begin{array}{l}0.000298 \\
0.0262\end{array}$ \\
\hline X4899 G030 & 55.7 & 14.7 & 0.7123 & 0.08946 & 0.00306 \\
\hline X4899 G031 & 241.1 & 22.4 & 0.1923 & 0.05673 & 0.00182 \\
\hline $\begin{array}{l}\text { X4899 G032 } \\
\text { X4899 G033 }\end{array}$ & $\begin{array}{l}895.9 \\
885.6\end{array}$ & $\begin{array}{r}167.1 \\
95.9\end{array}$ & $\begin{array}{r}0.4904 \\
0.226\end{array}$ & $\begin{array}{l}0.21105 \\
0.27058\end{array}$ & $\begin{array}{r}0.00544 \\
0.0071\end{array}$ \\
\hline X4899 G034 & 130 & 39.6 & 0.0233 & $\begin{array}{r}0.1118 \\
0.278\end{array}$ & 0.00306 \\
\hline X4899_G035 & 339.5 & 77.3 & 0.5411 & 0.07956 & 0.00218 \\
\hline X4899_G036 & 106.7 & 19.6 & 0.3745 & 0.0802 & 0.0025 \\
\hline X4899_G037 & 231.6 & 11.1 & 0.3655 & 0.04996 & 0.00194 \\
\hline X4899_G038 & 45.4 & 8.8 & 1.0742 & 0.07036 & 0.00286 \\
\hline X4899_G039 & 132 & 54.3 & 0.7044 & 0.12279 & 0.00334 \\
\hline X 4899 G040 & 71.5 & 51.2 & 0.7458 & 0.19946 & 0.00536 \\
\hline X4899_G041 & 1026.7 & 74.8 & 0.7556 & 0.31737 & 0.00846 \\
\hline X4899_G042 & 35.2 & 4.4 & 0.4933 & 0.06564 & 0.0032 \\
\hline $\begin{array}{r}X 4899 \\
\times\end{array} 043$ & 90.9 & 55 & 1.1224 & $\begin{array}{r}0.2685 \\
0.74766\end{array}$ & $\begin{array}{l}0.00716 \\
0.0846\end{array}$ \\
\hline $\begin{array}{l}\times 4899 \\
\times 4899 \\
G\end{array} 045$ & 30.8 & 21.7 & 0.9743 & 0.19701 & $\begin{array}{l}0.00566 \\
0.0596\end{array}$ \\
\hline X4899 G046 & 70.3 & 12.5 & 0.5125 & 0.07391 & 0.0028 \\
\hline X4899_G047 & 503.1 & 153 & 0.0293 & 0.11328 & 0.00302 \\
\hline X4899_G048 & 81 & 8.3 & 0.3744 & 0.05961 & 0.00274 \\
\hline X4899_G049 & 200.4 & 38.6 & 0.4363 & 0.09616 & 0.0028 \\
\hline X4899_G050 & 95.6 & 54 & 0.4761 & 0.16836 & 0.00468 \\
\hline X4899_G051 & 142.3 & 24.9 & 0.3189 & 0.07278 & 0.00232 \\
\hline X4899_G052 & 82.6 & 9.3 & 0.4314 & 0.06167 & 0.00266 \\
\hline X4899_G053 & 100.4 & 43 & 0.715 & 0.14454 & 0.00426 \\
\hline X4899_G054 & 66.8 & 8.8 & 0.81 & 0.06496 & 0.00312 \\
\hline X4899 G055 & 128 & 46.2 & 0.7034 & 0.1126 & 0.00332 \\
\hline X4899 G056 & 39.1 & 26.8 & 1.2681 & 0.18244 & 0.00554 \\
\hline X4899 G057 & 56.5 & 28.1 & 1.5875 & 0.11918 & 0.0037 \\
\hline X4899 G058 & 103.9 & 16.8 & 0.531 & 0.09831 & 0.00324 \\
\hline X4899_G059 & 20.6 & 4.5 & 0.6126 & 0.09568 & 0.0046 \\
\hline X4899_G060 & 132 & & 1.7774 & 0.12632 & 0.00352 \\
\hline X4899_G061 & 21.7 & 9.2 & 0.7196 & 0.18168 & 0.00612 \\
\hline X4899_G062 & 143.9 & 56.8 & 0.542 & 0.11925 & 0.0033 \\
\hline X4899_G063 & 1834.1 & 187.4 & 0.5502 & 0.15154 & 0.00408 \\
\hline X4899_G064 & 39.9 & 3.4 & 0.0344 & 0.06302 & 0.0033 \\
\hline X4899_G065 & 60.5 & 6 & 0.9035 & 0.05818 & 0.00326 \\
\hline X4899_G066 & 41.5 & 5.5 & 0.9814 & 0.06206 & 0.00302 \\
\hline X4899 G067 & 66.8 & 11.5 & 0.4921 & 0.07188 & 0.00272 \\
\hline X4899 G068 & 211.8 & 33.3 & 27.0992 & 0.56459 & 0.01568 \\
\hline X4899 G069 & & & & 0.19429 & 0.965 \\
\hline $\begin{array}{l}\text { X4899 G070 } \\
\text { X4899_G071 }\end{array}$ & 440.6 & 174.2 & 0.4713 & $\begin{array}{l}0.87093 \\
0.12568\end{array}$ & $\begin{array}{r}0.05016 \\
0.0034\end{array}$ \\
\hline & 28.1 & 2.9 & 0.7729 & 0.05971 & $\begin{array}{l}0.0034 \\
0.0045\end{array}$ \\
\hline X4899_G073 & 41.9 & 26 & 0.4696 & 0.1801 & 0.0052 \\
\hline X4899_G074 & 1067.4 & 382.9 & 0.0498 & 0.16724 & 0.00444 \\
\hline X4899_G075 & 77.1 & 12 & 0.3737 & 0.07072 & 0.0025 \\
\hline X4899_G076 & 239.1 & 19.6 & 0.4048 & 0.05627 & 0.00186 \\
\hline X4899_G077 & 37.9 & 4 & 0.2478 & 0.05958 & 0.00296 \\
\hline X4899_G078 & 101.2 & 18.5 & 0.5973 & 0.07096 & 0.0023 \\
\hline X4899 G079 & 44.7 & 18.5 & 0.5774 & 0.12577 & 0.00392 \\
\hline X4899 G080 & 51.8 & 4.2 & 0.0053 & 0.05838 & 0.00282 \\
\hline X4899 G081 & & & & $\begin{array}{l}0.14154 \\
0.11766\end{array}$ & $\begin{array}{l}0.38658 \\
0.00388\end{array}$ \\
\hline $\begin{array}{l}\text { X4899 G082 } \\
\text { X4899_G083 }\end{array}$ & $\begin{array}{r}27.7 \\
238.3\end{array}$ & $\begin{array}{r}12 \\
25.1\end{array}$ & $\begin{array}{l}0.8084 \\
0.1702\end{array}$ & $\begin{array}{l}0.11766 \\
0.06099\end{array}$ & $\begin{array}{l}0.00388 \\
0.00192\end{array}$ \\
\hline $\begin{array}{l}\text { X48999GU83 } \\
\text { X4899_G084 }\end{array}$ & 164 & 13.8 & 0.2936 & $\begin{array}{r}0.060567 \\
0.057\end{array}$ & 0.00214 \\
\hline X4899_G08 & 363.2 & 32.6 & 0.5 & 0.05909 & 0.00186 \\
\hline X4899_G0 & $\begin{array}{l}295.6 \\
845\end{array}$ & 49.5 & 0.0685 & 0.08055 & 0.00234 \\
\hline X4899_G0 & 846.5 & 196.5 & & 0.12477 & 0.00342 \\
\hline X4899_G0 & 228 & 93.4 & & 0.12067 & 0.00334 \\
\hline X4899_G08 & 24.9 & 4. & & 0.07072 & 0.00 \\
\hline X4899_G09 & 82.6 & 8 & & 0 & 0.00252 \\
\hline X4899 G0S & 130.8 & 33 & & & 0.00 \\
\hline X4899 G092 & 150.2 & 56 & & 0.11758 & 0.00334 \\
\hline X4899 G09: & 410.6 & 37.4 & 0.3 & 0.07436 & 0.0023 \\
\hline X4899 G094 & $\begin{array}{r}73.5 \\
122.1\end{array}$ & 6. & & & 0.00246 \\
\hline $\begin{array}{l}\text { X4899_G095 } \\
\text { X4899_G096 }\end{array}$ & $\begin{array}{r}122.1 \\
33.2\end{array}$ & $\begin{array}{r}23.3 \\
6.9\end{array}$ & $\begin{array}{l}0.6777 \\
0.444\end{array}$ & $\begin{array}{l}0.08616 \\
0.08644\end{array}$ & $\begin{array}{l}0.00268 \\
0.00354\end{array}$ \\
\hline
\end{tabular}

